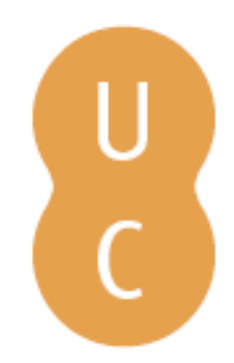

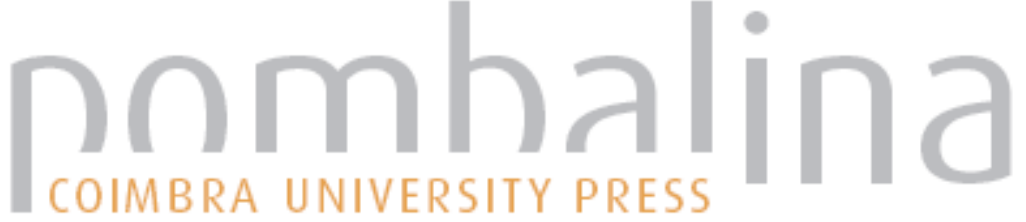

\section{Ensaios sobre o tempo na filosofia antiga}

\author{
Autor(es): $\quad$ Puente, Fernando Rey
}

Publicado por: Imprensa da Universidade de Coimbra

URL

persistente: URI:http://hdl.handle.net/10316.2/32754

DOI: $\quad$ DOI:http://dx.doi.org/10.14195/978-989-26-0848-8

Accessed : $\quad$ 26-Apr-2023 16:14:13

A navegação consulta e descarregamento dos títulos inseridos nas Bibliotecas Digitais UC Digitalis, UC Pombalina e UC Impactum, pressupõem a aceitação plena e sem reservas dos Termos e Condições de Uso destas Bibliotecas Digitais, disponíveis em https://digitalis.uc.pt/pt-pt/termos.

Conforme exposto nos referidos Termos e Condições de Uso, o descarregamento de títulos de acesso restrito requer uma licença válida de autorização devendo o utilizador aceder ao(s) documento(s) a partir de um endereço de IP da instituição detentora da supramencionada licença.

Ao utilizador é apenas permitido o descarregamento para uso pessoal, pelo que o emprego do(s) título(s) descarregado(s) para outro fim, designadamente comercial, carece de autorização do respetivo autor ou editor da obra.

Na medida em que todas as obras da UC Digitalis se encontram protegidas pelo Código do Direito de Autor e Direitos Conexos e demais legislação aplicável, toda a cópia, parcial ou total, deste documento, nos casos em que é legalmente admitida, deverá conter ou fazer-se acompanhar por este aviso.

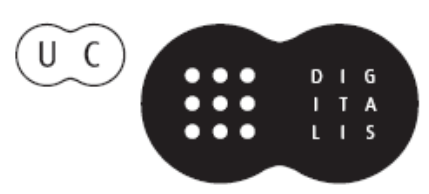




\section{Ensaios sobre}

\section{o tempo na}

Filosofia

Antiga

FERnANDO Rey PuEnte

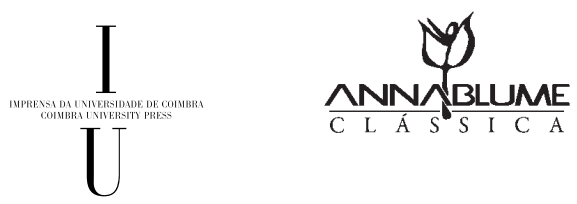


(Página deixada propositadamente em branco) 


\section{Ensaios sobre \\ o tempo na \\ Filosofia \\ Antiga}


(Página deixada propositadamente em branco) 


\section{Ensaios sobre}

o tempo na

Filosofia

Antiga

Fernando Rey Puente

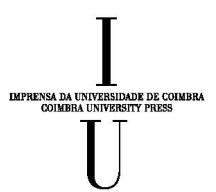

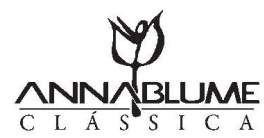




\section{COEDIÇÃO}

Imprensa da Universidade de Coimbra URL: http://www.uc.pt/imprensa_uc

ANNABLUME editora . comunicação www.annablume.com.br

\section{PROJETO E PRODUÇÃO}

Coletivo Gráfico Annablume

\section{IMPRESSÃO E ACABAMENTO}

LinkPrint

ISBN

978-989-26-0261-5 (IUC)

978-85-391-0154-2 (Annablume)

ISBN Digital

978-989-26-0848-8

DOI

http://dx.doi.org/10.14195/978-989-26-0848-8

DEPÓSITO LEGAL

$350537 / 12$

(C) JUNHO 2012

ANNABLUME

IMPRENSA DA UNIVERSIDADE DE COIMBRA 
Aos meus alunos, que têm me permitido, mesmo diante de tantas e às vezes ingratas tarefas da vida universitária, poder continuar sendo um estudante de filosofia. 
(Página deixada propositadamente em branco) 


\section{AGRADECIMENTOS}

\footnotetext{
S estudos aqui apresentados só puderam ser reunidos e publicados graças ao apoio recebido por meio da bolsa "Pesquisador Mineiro" concedida pela Fapemig ao autor durante os anos de 2008 a 2010. A essa instituição, portanto, os meus mais sinceros agradecimentos.

Gostaria de agradecer também os diretores da nascente coleção Archai da editora Annablume, especialmente ao Prof. Gabriele Cornelli que aceitou generosamente incluir minha modesta contribuição em sua nova e, estimo, exitosa coleção voltada para os estudos sobre a Antiguidade.

Por fim, mas não em último lugar, gostaria de agradecer também aos inúmeros alunos que tendo frequentado minhas aulas na UFMG durante a última década enriqueceram-nas com suas perguntas e inquietações me auxiliando assim a constatar o fato, a cada dia mais evidente para mim, de que na tarefa do pensamento estamos sempre começando.
} 
(Página deixada propositadamente em branco) 


\section{SUMÁRIO}

NORMAS DE TRANSLITERAÇÃO DOS TERMOS GREGOS 11

INTRODUÇÃO: O EFÊMERO (EPHÉMEROS) E A PRODUÇÃO ACADÊMICA ATUAL 13

1. ALGUMAS FIGURAS DO TEMPO DE HOMERO E ARISTÓTELES $\quad 21$

2. O SÚBITO (EXAÍPHNESS) EM PLATÃO 47

3. TEMPO E LIBERDADE: DO FINALISMO ARISTOTÉLICO AO FATALISMO ESTÓICO 61

4. TEMPO E AÇÃO EM ARISTÓTELES 95

5. OBSERVAÇÕES SOBRE O TEMPO NAS MEDITAÇÕES DE MARCO AURÉLIO

6. O TEMPO E A ALMA: UM ESTUDO COMPARATIVO

ENTRE ARISTÓTELES E PLOTINO 
(Página deixada propositadamente em branco) 


\section{NORMAS DE TRANSLITERAÇĀO DOS TERMOS GREGOS}

\footnotetext{
- mpregamos as normas adotadas pela Sociedade CBrasileira de Estudos Clássicos (SBEC), com a única exceção de grafar as vogais longas do grego não com um traço acima das vogais como recomendado, mas com um traço abaixo delas (assim o $\eta$ será transliterado por e e o $\omega$ por $\underline{o})$.
} 
(Página deixada propositadamente em branco) 


\title{
INTRODUÇÃO
}

\author{
O EFÊMERO (EPHÉMEROS) E A PRODUÇÃO \\ ACADÊMICA ATUAL
}

D entre os vários termos relacionados a algum modo de vivenciar o tempo que encontramos em diversos pensadores da Antiguidade, um deles em particular é especialmente propício para caracterizar a produção acadêmica hodierna - que vive há já algumas décadas, como todos sabemos muito bem, sob o veredicto, não por acaso conhecido no idioma científico da contemporaneidade, publish or perish! - qual seja: ephémeros (literalmente: o que dura um dia).

Os antigos gregos se utilizaram muitas vezes do adjetivo ephémeros para caracterizar a brevidade e a fragilidade ínsitas à vida humana. Um deles, um dos mais renomados poetas da Grécia, o tebano Píndaro, que tinha como tarefa escrever poemas em louvor dos jovens atletas vencedores de um dos quatro grandes concursos pan-helênicos da Antiguidade, e que era particularmente sensível ao caráter fugaz e efêmero das vitórias obtidas nessas competições de cunho 
primordialmente religioso ocorridas em Olímpia, em Delfos, cujo santuário denominava-se Pítia, no Istmo de Corinto e em Neméia (daí as odes de Píndaro serem subdivididas e respectivamente intituladas de Olímpicas, Piticas, Ístmicas e Nemeanas) escreveu alguns célebres versos utilizando essa ideia. Assim, se os imortais versos 95-96 da Oitava Pitica: epámeroi. tí dé tis; tí d'oú tis; skiâs ónar ánthropos ("Efêmeros. Ser alguém? Ser ninguém? Sonho de uma sombra é o homem”) - que despertaram tanto interesse e controvérsia entre doutos estudiosos da poesia grega arcaica desde a publicação do conhecido capítulo de Hermann Fränkel dedicado a exegese dessas linhas imortais em sua consagrada obra sobre o pensamento grego antigo ${ }^{1}$ - são magnificamente adequadas para caracterizar a vida humana em sua fragilidade e brevidade constitutivas ao adjetivá-la como "sonho de uma sombra", como então nós deveríamos caracterizar grande parte da produção acadêmica atual? De que forma então nós deveríamos

1 Cf. Hermann Fränkel, "EథHMEPO $\Sigma$ als Kennwort für die menschliche Natur”, in: H. Fränkel, Wege und Formen frühgrieschischen Denkens, Beck, München, 1955. Para uma análise crítica da interpretação proposta por Fränkel da noção de ephémeros ver Matthew W. Dickie, "On the meaning of $\varepsilon \varphi \eta \mu \varepsilon \rho \circ \varsigma^{\prime}$, Illinois Classical Studies, 1, 1976. Uma obra essencial para compreender não apenas a oitava Pítica de Píndaro, mas a sua poesia como um todo em um registro filosófico, com especial atenção à dimensão temporal é o excelente livro de Michael Theunissen, Pindar. Menschenlos und Wende der Zeit, Beck, München, 2000 (sobre a interpretação da noção de efêmero na oitava Pítica consultar o primeiro capítulo da primeira parte do primeiro livro, pp. 45-78). 
adjetivar os breves ensaios por nós aqui reunidos? Se o termo efêmero descreve a nossa vida como o sonho de uma sombra, como denominá-los? Fugazes vaidades do sonho de uma sombra? Mais importante: por que então resolver publicá-los?

As razôes para fazê-lo parecem-me duas. A primeira é de ordem exclusivamente pessoal. $\mathrm{O}$ autor pretende com essa publicação liberar-se de certa forma de um tema que o tem ocupado há muito tempo. Talvez a própria efemeridade da vida o force a isso, pois muitos dos textos aqui reunidos fazem parte de projetos e ideias que o autor não sabe mais se terá o tempo, a capacidade ou a possibilidade de empreender. Sendo assim, por que não apresentá-los nesse estado embrionário? Talvez a prática docente e a reflexão cotidiana que todos nós fazemos de nossas vidas tenham dado ao autor a crença de que alguma ideia ou intuição, ainda que imperfeitas e inacabadas, possam fecundar alguma outra mente que poderá vir a lhe conferir um dia uma forma melhor e mais acabada. Na verdade, o autor gostaria de escrever um tratado minucioso e o mais completo possível sobre as diversas figuras do tempo no mundo grego antigo, mas realmente não sabe se terá o fôlego e o tempo necessário para fazê-lo, dado o escasso tempo realmente livre de que se dispõe atualmente na vida acadêmica para a realização de uma pesquisa mais paciente e minuciosa e sem resultados em curto prazo. Parece-nos ficar cada vez mais difícil amadurecer e desenvolver lentamente as ideias em clima de verdadeiro ócio em meio à profusão de aulas que temos de preparar, de alunos - de graduação 
e pós-graduação - que temos de orientar, de relatórios e pareceres que temos de escrever, bem como de dissertações e teses que temos de ler, dentre outras burocráticas funçôes que temos de desempenhar em nossa atribulada vida acadêmica hodierna.

Essa ideia de que algum dos textos aqui reunidos possa despertar o interesse de um eventual leitor, trazme à mente outra figura do tempo bastante apreciada na Antiguidade, a saber, o kairós, o tempo oportuno. Assim, e essa é a segunda razão a que aludi acima como justificativa para publicá-los, o autor espera poder contar com a intervenção desse tempo oportuno na vida de seus potenciais leitores. A esperança é que esses textos possam vir a despertar o interesse de algum deles pelos pensadores aqui em estudo ou mesmo pelo tema que me proponho a investigar nesses autores, o tempo; e igualmente que essa leitura possa ser a ocasião favorável ou o momento oportuno para esses eventuais leitores empreenderem esse estudo mais minucioso.

Quando penso na quantidade imensa de publicações produzidas nas últimas décadas (dentre as quais obviamente incluo as minhas próprias), fico me perguntando o que delas sobreviverá daqui a cem anos. Talvez não seja preciso nem mesmo pensar em cem anos... Evidentemente, muito pouco. Assim, não me parece que em nossos dias um autor em plena sanidade mental possa buscar a justificativa para a publicação de alguns artigos escritos circunstancialmente sobre um tema em uma pretensa perpetuidade do texto escrito, pois ela inexiste. As únicas duas justificativas cabíveis para se publicar um livro em nossos dias de excesso 
de publicações me parecem essas mesmas que acabei de mencionar: uma espécie de esvaziamento em relação a um tema para o próprio autor, ou seja, um processo catártico dele próprio que precisa de algum modo se libertar de um pensamento ou tema de que se ocupa para poder criar espaço interior para novos autores e assuntos; e a esperança que algum texto possa despertar um interesse em um eventual leitor de se aprofundar no autor analisado ou na questão tratada. Rapidamente os textos publicados serão esquecidos, pois novas publicações estarão surgindo a cada mês ou ano. A maior parte das publicações hodiernas, portanto, só podem se justificar no melhor dos casos sob o signo do kairós. Que um ou outro desses meus breves e efêmeros textos possa, por conseguinte, evocar o interesse de algum leitor em ler algum texto de Platão, Aristóteles, Marco Aurélio ou Plotino, isso já justificaria plenamente a sua publicação. $\mathrm{Ou}$, quem sabe, que um ocasional leitor se sinta estimulado a analisar mais atenta e detidamente do que me foi possível fazer nestes textos a questão do tempo no pensamento antigo.

Dos textos aqui compilados, somente dois já haviam sido publicados previamente. Os outros quatro permaneciam inéditos até a presente publicação. Desses textos inéditos, dois deles, são breves e indicam apenas o início de uma pesquisa a que o autor não pode dar um desenvolvimento mais acabado, a saber, "O súbito (exaíphness) em Platão" (apresentado oralmente no X Encontro Nacional de Filosofia - Anpof 2002) e "Observaçōes sobre o tempo nas Meditaçôes de Marco Aurélio" (apresentado oralmente no XI 
Encontro Nacional de Filosofia - Anpof 2004). Os outros dois desses textos inéditos representam, por um lado, um projeto de pesquisa desenvolvido entre 2000 e 2004 no Departamento de Filosofia da UFMG (é o caso do texto "Tempo e liberdade: do finalismo aristotélico ao fatalismo estóico") e, por outro, da apresentação genérica intitulada "As figuras do tempo de Homero a Aristóteles”, início da idéia de pesquisar a noção de tempo no mundo grego e escrita provavelmente no final dos anos 90. Por fim, a republicação dos dois textos já anteriormente publicados - devido a sua pouca acessibilidade e pelo fato de tratarem igualmente da questão do tempo - pareceu oportuna ao autor. $\mathrm{O}$ artigo “Tempo e ação em Aristóteles” é o novo nome para o artigo "Télos como arché e o fundamento da ação em Aristóteles" publicado pela primeira vez no Boletim do CPA, vol. V do ano 2000 e o artigo "O tempo e a alma em Aristóteles e Plotino" já havia sido publicado com o mesmo título no livro Amor Scientiae. Festchrift em homenagem a Reinholdo Aloysio Ullmann, organizado por Draiton de Souza e editado pela EDIPUCRS no ano de 2002.

Aceitamos plenamente o duro, mas realista contato com o nosso passado como um exercício de humildade intelectual. Procuramos não alterar significativamente nenhum dos ensaios, mas apenas corrigir alguns erros dos textos anteriormente publicados, esclarecer alguns pontos obscuros dos demais escritos e acrescentar uma ou outra referência bibliográfica. Olhar para o passado de nossa produção teórica cristalizado em nossos textos é aceitar nossos limites intelectuais. Digeri-los 
e pretender estar fazendo ou, ao menos, poder vir a fazer algo melhor.

$\mathrm{O}$ autor, por meio dessa publicação, espera apenas - plenamente ciente das limitaçôes dos textos aqui reunidos - que seus efêmeros ensaios possam em alguma medida vir a fecundar o espírito de seus eventuais leitores, jovens ou leigos, despertando neles o gosto pela filosofia e/ou o interesse pelo intrigante e talvez irresolúvel enigma do tempo, um enigma que, como todas as grandes aporias do pensamento, nos acompanhará sem solução definitiva até o fim de nossos dias. 
(Página deixada propositadamente em branco) 


\section{ALGUMAS FIGURAS DO TEMPO DE HOMERO E ARISTÓTELES}

U

$\mathrm{m}$ erro bastante comum ao analisarmos outras épocas históricas é o de inconscientemente transferirmos a elas valores e conceitos que lhes são estranhos e, algumas vezes, até mesmo essencialmente antagônicos. Conceitos que nos parecem, em um primeiro momento, tão universais e homogêneos, como, por exemplo, os de espaço, tempo e número, mostramse, no mais das vezes, caleidoscopicamente variegados, confirmando assim, a diversidade cultural e histórica que nos separa de outras civilizaçôes e de outros períodos históricos. Por outro lado, esta cisão não é absoluta ou intransponível, restando-nos, como sempre, a delicada tarefa de mantermo-nos igualmente afastados de posições extremas ou, para dizê-lo usando metáforas oriundas do imaginário grego, resta-nos a sutil missão de permanecermos incólumes entre a Cila do relativismo e a Caríbdis do universalismo acrítico. Nunca nos esqueçamos, enfim, de que o limite que nos separa de 
outras épocas históricas ou de outras civilizaçōes é ao mesmo tempo o limiar a partir do qual entramos em contato com elas.

Justifiquemos, em primeiro lugar, o uso do plural no título deste texto. Os gregos, de Homero a Aristóteles, mas obviamente os da Era Helenística também, conceberam diferentes ideias sobre o tempo. $\mathrm{Na}$ verdade, eles desconheceram um conceito-chave - $o$ tempo - sob o qual pudessem subsumir as distintas experiências e impressões que o fenômeno temporal lhes produzia.

Em uma época de ampla divulgação cultural como a nossa, costuma-se elaborar e difundir esquemas simplificadores para dar conta de algumas diferenças histórico-culturais. Por meio de alguns desses esquemas (por exemplo, os de G. Scholen e J. Taubes), propagou-se, entre grande parcela do público letrado, a suposição de que os gregos defendiam uma visão exclusivamente cíclica do tempo, enquanto os hebreus caracterizar-se-iam por uma concepção estritamente linear do mesmo. Esta suposição, contudo, mostra-se parcial e incompleta ante uma análise mais atenta e rigorosa e parece originar-se na reconstrução tendenciosa que Nietzsche elaborou do mundo antigo ${ }^{2}$.

2 Cf. H. Cancik, "Die Rechtfertigung Gottes durch den 'Fortschritt der Zeiten'. Zur Differenz jüdisch-christlicher und hellenisch-römischer Zeit- und Geschichtesvorstellungen”, in: Die Zeit. Dauer und Augenblick, Hrsg. H. Gumin und H.Meier, Piper, München, 1990, p.257-288. 
Essas duas formas básicas de conceber metaforicamente o tempo - como circunferência e como linha reta - estão intimamente relacionadas com dois modos elementares, porém evidentemente não exclusivos, de se vivenciar o tempo. Os gregos vivenciaram-no tanto como um processo repetitivo, quanto como um escoar irreversível, além de outros modos, como veremos a seguir. Para a solidificação dessa primeira vivência contribuiu, no âmbito da natureza, a constatação do ciclo periódico das estações, bem como a observação dos movimentos cotidianos, mensais e anuais de alguns corpos celestes e, no âmbito da cultura, o retorno anual das festas religiosas. Já para a fixação da segunda, concorreram as reflexões sobre o caráter irrevogável das ações passadas, a transitoriedade da juventude, a chegada dolorida da senectude e a proximidade irremediável da morte. O substantivo feminino grego periodos (literalmente: "caminho ao redor de") possui tanto o sentido de um movimento circular realizado no espaço, quanto o de um ciclo repetido no tempo, daí esse mesmo termo indicar para os helenos quer a revolução dos astros no céu, quer os quatro principais Jogos ou Festivais gregos (Olímpicos, Píticos, Nemeanos e Ístimicos).

Exploremos, a seguir, ainda que apenas em termos muito gerais, a concepção pré-filosófica do tempo presente em Homero e Hesíodo, os dois poetas formadores da Hélade. Esta concepção, como veremos, não parece poder ser plenamente compreendida com o auxílio das metáforas de ciclo e reta que mencionamos anteriormente, dado o seu caráter mais concreto, dis- 
tinto, portanto, das generalizações filosóficas posteriores que, de certo modo, condicionam hodiernamente nosso olhar retrospectivo sobre essa época.

Homero e Hesíodo, seguindo os estudos pioneiros e já clássicos de R. B. Onians e de H. Fränkel, desconheceram um conceito abstrato e homogêneo do tempo. Eles usaram preferencialmente as palavras êmar e hóra, ambas de riquíssimo conteúdo semântico para exprimir em seus poemas as diferentes vivências que os homens tinham do tempo em diversas circunstâncias de suas vidas. ÊEmar, por exemplo, pode significar o dia em oposição à noite, uma estação ou época do ano, certa duração ou, quando adjetivado, qualificar um estado ou condição, como, por exemplo, o dia do retorno (ếmar nóstimon, Od.1,9), o dia da morte (ếmar mórsimon, Il.15, 613), o dia da libertação (êmar eleútheron, Il.6,455) ou o dia da escravidão (ệmar doúlion, Il.6, 463). Este último uso de ếmar, no qual ele é definido por um adjetivo, expressa, segundo Fränkel, "o destino particular do indivíduo durante um tempo específico"3, sendo equivalente ao termo ầsa ("destino"). Hora também é um vocábulo plurisemântico. Ele pode significar qualquer divisão do tempo, de modo que, às vezes, indica o ano, outras vezes ele se refere a um período do mês, do dia ou da noite. Além desses significados, ele pode referir-se igualmente às estaçóes do ano ou ainda assinalar um tempo oportuno e propício para realizar alguma ati-

3 Cf. Fränkel, p.414, 
vidade, recobrindo assim o espectro semântico que o termo kairós ("ocasião/momento oportuno") receberá posteriormente em âmbito filosófico. Isso parece se comprovar pelo fato de que kairós não ocorre nenhuma vez em Homero e, em Hesíodo, apenas uma única vez. Também as palavras khrónos e aión que em séculos vindouros assumirão um papel fundamental na representação do tempo, descrita e analisada por vários filósofos, desempenham tanto em Homero quanto em Hesíodo um papel apenas secundário.

De modo geral, pode-se dizer que os gregos arcaicos pareciam acreditar que as diversas "partes" do tempo dias e horas - possuíam diferentes atributos, que elas trouxessem alguma modificação qualitativa ou que favorecessem particularmente alguma atividade dos homens. O poema Os Trabalhos e os Dias de Hesíodo, na verdade, é uma longa exposição deste caráter essencialmente qualitativo dos dias e das horas (cf. p.ex. os versos 414ss.; 765ss.; 782ss. e 822ss.). Esses "tempos" distintos, portanto, modificavam os homens em seus afazeres cotidianos de modo íntimo e profundo. Dias e horas, segundo essa visão, submetiam a alma dos seres humanos ao seu caráter fasto ou nefasto, influenciando assim, de modo decisivo, as ações presentes e, por conseguinte, o destino dos mesmos.

Como havíamos dito há pouco, não podemos representar adequadamente essas figuraçôes do tempo presentes em Homero e em Hesíodo, nem com o atributo de um tempo cíclico/reversível, nem com o de um tempo linear/irreversível. A Teogonia, por exemplo, nos mostra isso com clareza. Em uma feliz 
formulação de J. Torrano, a concepção temporal ínsita a este célebre poema de Hesíodo não se expressa "segundo o princípio cronológico do antes-e-depois, mas segundo o princípio crato-onto-lógico da forçade-ser”" . Em outras palavras, os deuses não se sucedem cronologicamente, segundo um tempo oniabrangente e homogêneo. Cada divindade que aparece no poema é uma força-de-ser prestes a se manifestar, a tornarse presente, a ser uma Presença, concepção essa que será recuperada muitos séculos depois por Schelling em suas profundas e ainda hoje pouco conhecidas reflexões sobre a mitologia contidas particularmente em sua obra Philosophie der Mythologie.

Na passagem da Grécia Arcaica (VIII-VI séc. a.C.) para a Grécia Clássica (V-IV séc. a.C.) faz-se mister mencionar duas importantes figuras de transição: Píndaro e Ésquilo. O primeiro, um dos últimos representantes da poesia lírica que remontava a uma tradição oriunda do século VII a.C., e o segundo, o primeiro dos grandes dramaturgos da Era Clássica. Ambos foram, segundo Fränkel, elos essenciais na mudança que o conceito de tempo sofrerá na transição da Era Arcaica para a Clássica (cabe lembrar que ambos os autores nasceram no final do século VI a.C., mas que escreveram as suas obras já no século $\mathrm{V}$ a.C., ou seja, na aurora do Classicismo).

Fränkel nos adverte para o fato do vocábulo khrónos em Píndaro ser revestido da carga semântica que o termo

4 Teogonia. Estudo e tradução de Jaa Torrano, São Paulo, 1986, p.112. 
êmar possuía outrora em Homero. Khrónos, segundo o importante exegeta alemão, expressa nas Odes essencialmente o que a de vir, ou seja, o porvir (cf. Pit. 4,78 ; Ol. 1,115). Por outro lado, a impotência de khrónos, "o pai de todas as coisas", diante do que já foi realizado, é claramente expressa pelo poeta nos versos 15 a 17 da segunda Ode Olímpica. Quando Píndaro quer se referir ao passado, ele se utiliza de advérbios como pálai ("antigamente") e pote ("um dia")5. Seguindo, como sempre, a interpretação de Fränkel, nós poderíamos afirmar que, apenas com Píndaro, conquistou-se a dimensão do porvir para o termo khrónos. Todavia, este sentido do futuro não era totalmente estranho à concepção temporal presente em Homero e Hesíodo - embora estes o expressassem por meio de outros vocábulos, como vimos anteriormente -, pois para eles os dias e as horas eram portadores de determinadas qualidades que advinham aos homens com a mesma inexorabilidade com que o destino lhes sobrevinha ${ }^{6}$. Ainda de acordo com Fränkel, a dimensão pretérita do termo khrónos só foi plenamente elaborada na Era Clássica, mais precisamente, nas últimas tragédias de Ésquilo (cf. Ag. v.278; Eum. v.462, ambas exibidas em 458 a.C.). Isso ocorreu, segundo o importante exegeta alemão, devido à interiorização do fenômeno temporal levado a cabo na Grécia Clássica. Nesta fase, khrónos parece ser pensado, ao menos de acordo com

\footnotetext{
5 Cf. Fränkel, p. 11.

6 Cf. Fränkel, p. 13.
} 
a análise de alguns dos mais importantes estudiosos sobre esse assunto, como um elemento ínsito à consciência humana e não mais como uma força extrínseca aos homens.

Segundo J.de Romilly, que interpretou magistralmente a problemática do tempo na tragédia grega, em Píndaro tem início uma transformação da concepção do tempo que amadurecerá plenamente na obra dos trágicos, ou ainda, invertendo esta formulação e empregando as palavras da própria autora: "a tragédia nasce quando a consciência do tempo atinge o seu pleno desenvolvimento"7. Para esta intérprete, portanto, a essência mesma da tragédia está intimamente vinculada à dimensão temporal. "Toda tragédia apresenta e comenta um efeito do tempo" 8 e ela, de acordo com Romilly, "exprime sempre, queira ou não o autor, uma certa filosofia do tempo" .

Em sua exegese, Romilly identifica dois estágios inerentes ao processo de personificação do tempo que ela constata e documenta em seu livro: primeiramente, ele é visto como uma mera testemunha universal que observa, sem interferir, todos os acontecimentos da vida humana; posteriormente, contudo, passa-se a atribuir ao mesmo um papel causal em relação a esses mesmos eventos. Isto é, ele passa, então, a ser visto como o responsável por esses acontecimentos. A ori-

7 Romilly, p. 10.

8 Ibid., p. 11.

9 Ibid., p. 15. 
gem deste processo de personificação do tempo deuse, provavelmente, no seio da tradição órfica, dado ser nela que, segundo alguns intérpretes, parece ter ocorrido a confusão da divindade Krónos, pai de Zeus, segundo Hesíodo, com khrónos, o tempo. Há três fragmentos atribuídos por Damáscio (um autor do IV séc. d.C.), considerado o último neoplatônico ateniense, a Orfeu, nos quais o tempo aparece como uma divindade, Khrónos, pai do Éter e do $\operatorname{Caos}^{10}$. Existe ainda um fragmento de Ferécides (que viveu em meados do séc. VI a.C.) recolhido por Diógenes Laércio, onde este autor também afirma a divindade de khrónos $^{11}$. Enquanto alguns exegetas, como Romilly, acreditam que esta confusão entre Krónos e khrónos possa ter sido originada, na verdade, apenas nos meios neoplatônicos da Era Helenística (IV-I séc. a.C.) que coligiram os fragmentos da tradição órfica, outros, como Colli, acreditam na autenticidade do reconhecimento da divindade de khrónos por parte dos órficos. A questão como se vê é controversa e dificilmente poder-se-á alcançar um consenso universal entre os mais importantes estudiosos do assunto.

As passagens contidas nas obras dos autores clássicos, que expressam a concepção de khrónos como testemunha do devir universal, atribuem ao tempo a ação de revelar ou trazer à luz alguma coisa ou algum evento. Píndaro, por exemplo, chega até mesmo a

10 Cf. G. Colli, vol.I, p.281: 4[B72]a,b ; 4[B73].

11 Cf. Colli, vol.II, p.79: 9[A1]. 
denominá-lo "a única testemunha da verdade autêntica" $(\mathrm{Ol} .10,53-4)$ e Eurípides, indo mais longe ainda nesta personificação de khrónos, afirma que "o tempo explicará tudo aos homens vindouros, porque ele é um tagarela que fala, mesmo sem ser interrogado" (frag.112 Nauck).

Outros trechos assinalados por Romilly referemse ao tempo como sendo o responsável e o causador dos acontecimentos que ocorrem na vida dos homens. A fim de que khrónos se solidarize com os homens, Píndaro elabora em seus poemas como que pequenas súplicas dirigidas a ele, nas quais the pede, entre outras coisas, que não destrua a felicidade $(\mathrm{Ol} .6,97)$ ou que não interrompa um curso favorável de eventos $(\mathrm{Ol} .8,28-9)$. Roga-lhe ainda que proteja os bens dos homens e que lhes proporcione o esquecimento dos seus sofrimentos (Pít. 1, 46). Novamente, Romilly vê em Eurípides a consumação deste processo de personificação (cf. Hérc. vv. 506-7: "o tempo é incapaz de preservar nossas esperanças: cumprida a sua tarefa, ele sai voando"). No último grande poeta trágico ela encontra então a personificação mais acabada de khrónos (no fragmento 42 de Nauck Eurípides chega a falar até mesmo em "passos do tempo") e a intérprete francesa constata, não sem certa ironia, que "o tempo grego só tornou-se uma divindade quando ele cessou de ser divino"12. Essa ironia se dá porque ela, como vimos, rejeita a hipótese da atribuição da divindade à khrónos

12 Romilly, p. 55. 
por parte dos órficos, aceitando apenas essa pseudodivindade com a qual ele passou a revestir-se, devido ao amplo processo de personificação - realizado pelos poetas trágicos com fins meramente artísticos - a que fora submetido.

Tendo abordado, ainda que apenas esquematicamente, as concepções não-filosóficas do tempo, resta-nos agora a tarefa de investigar, ainda que muito brevemente, o que alguns filósofos gregos anteriores a Platão pensaram sobre ele.

No âmbito da reflexão filosófica, o conceito de tempo, khrónos, paulatinamente diferenciado dos conceitos de eternidade (aión $)$ e instante $(\hat{n y} n)$, é pensado fundamentalmente em relação ao movimento (kinesis), embora no início do pensamento filosófico isto ocorra apenas de modo implícito. A palavra aión, por exemplo, que significava em Homero e Hesíodo "uma duração vital” recebe, nesse momento para alguns desses pensadores aurorais, o sentido mais radical de uma ausência mesma do tempo, logo, daquilo que nós entenderemos posteriormente como sendo a eternidade.

A tradição órfica, é oportuno recordar, também deixou alguns vestígios inegáveis de sua influência acerca desse tema na obra dos filósofos. Quando os órficos, por exemplo, referiam-se ao tempo como uma divindade, denominavam-no Khrónos agéraos, ou seja, “Tempo sem velhice", expressando assim o seu caráter divino e, portanto, imutável e eterno, por meio do seu prolongar-se indefinida e inalteradamente.

Muitos dos filósofos por nós denominados de présocráticos (em função da célebre coletânea de Diels 
aperfeiçoada posteriormente por Kranz) também sustentaram a tese de origem órfica, segundo R. Mondolfo, de que a eternidade é constituída pela sucessão de ciclos cósmicos. Entenda-se que subjaz a essa crença a ideia de um movimento ininterrupto e, portanto, eterno. Dentre esses pensadores, podemos citar especialmente três, a saber, Anaximandro, Empédocles e Heráclito.

Anaximandro caracteriza o ilimitado (ápeiros) exatamente como os órficos caracterizavam outrora o Tempo, isto é, ele denomina-o "sem velhice e incorruptível" (frag.2), bem como "imortal e indestrutível" (frag.3). Em Heráclito, o termo aión aparece expressamente, embora de modo um tanto obscuro: "tempo/ vida (aión) é criança brincando, jogando: reinado de uma criança” (frag. 52). G. Colli que sugere para este fragmento a tradução menos usual de aión por "vida", ao invés de "tempo", esclarece-nos que a criança a que Heráclito se refere não é outra senão o próprio deus Dioniso, que era, segundo o testemunho dos textos órficos, um menino ${ }^{13}$. Heráclito parece defender uma doutrina da identidade dos contrários, donde se depreende que o que está em cima e o que está em baixo (frag.60), o princípio e o fim (frag.103), o vivo e o morto (frag.88) e os mortais e os imortais (frag.62) são idênticos, pois tudo está em constante mutação no cosmo, sendo obra de um fogo "sempre vivo" (aeízoon) que sempre foi, é e será (frag.30). Heráclito, por conseguinte, parece conceber a infinitude temporal como

13 Colli, pp. 189-190. 
eminentemente cíclica, ou seja, ela é pensada, nas palavras de Mondolfo, como "a interminável sucessão de vicissitudes opostas"14. Esta mesma ciclicidade infindável dos opostos é explicada por Empédocles, por exemplo, graças à existência de duas forças contrárias que governam todas as mutações: o amor que atrai e o ódio que separa. Destas duas forças antagônicas o "tempo infinito" (áspetos aiọn) jamais se livrará, pois como eram outrora, assim o serão também no porvir (frag.16). Resumindo: parece que a ideia básica desses três pensadores a respeito desse tema é a da existência de uma eternidade (aión), mas não ainda pensada como uma pura e simples ausência do tempo, mas sim concebida como um estender-se infinitamente no tempo.

A rejeição dessa concepção cíclica da eternidade, segundo alguns intérpretes, parece iniciar-se com Anaxágoras que, seguindo os pitagóricos, postula um "circundante infinito" (frag.2) - que deve ser entendido, segundo Mondolfo, tanto espacial quanto temporalmente - anterior ao cosmo e no seio do qual esse emerge uma única e definitiva vez graças à ação do intelecto (nôेs), que é, ele mesmo, caracterizado por Anaxágoras como "ilimitado e autônomo" (frag.12) e "sempre existente" (frag.14).

A assim chamada Escola Eleática, ou seja, Parmênides, Zenão e Melisso, parecem afirmar a eternidade em sentido forte, relegando deste modo o tempo e o movimento à não-existência ou, ao menos,

14 Mondolfo, p. 85. 
a uma mera pseudo-existência. Para Parmênides, por exemplo, a eternidade é um atributo, por excelência, do ser que "nunca foi, nem será, porque é agora $(\hat{n y} n)$ todo junto, uno, contínuo" (frag.8, v.5). O Eleata assinala claramente nessa passagem a diferença entre a realidade do ser presente e a irrealidade, ou melhor, a impossibilidade ontológica desse ser que é agora ter sido ou vir a ser, dado que ele "nem era, é ou será outro fora do que é" (ibid., vv.36-7). Tanto a geração quanto a corrupção, portanto, não podem ser predicados desse ser que é "sem fim" (atéleston, ibid., v.4) e "sem princípio" (ánarkhon, ibid., v.27), sendo, em suma, "imóvel” (akineton, ibid., v.26). Mas, considerando-se a posição de Parmênides mais detalhadamente, pode-se observar que a extra-temporalidade do ser por ele defendida, entretanto, não parece ser absoluta - pelo menos segundo alguns intérpretes ${ }^{15}$-, pois ela se constitui pela afirmação ontológica do presente do verbo ser (estín) - do qual se afirma a existência - em contraposição à irrealidade ontológica de seus tempos passado (ênn) e futuro (éstai), dos quais a existência é negada. Parmênides, por conseguinte, necessita para pensar o ser eterno ao menos da dimensão presente do tempo. Em outras palavras: a eternidade, tal como ele parece conceber, não parece estar totalmente desvinculada da dimensão temporal. Um forte indicativo

15 Para uma análise minuciosa dessa questão em alguns intérpretes cf. D. O’Brien, “Temps et intemporalité chez Parménide”, Les Etudes Philosophiques, 3, 1980, p.257-272. 
a favor desta tese são os versos nove e dez do mesmo fragmento, onde Parmênides, refletindo acerca do ser, se pergunta: "que necessidade o teria impelido a nascer antes ou depois, se do nada iniciado?”. Aqui a sucessão temporal (o antes e o depois), como bem viu Mondolfo, não são condicionados pelo devir, antes são como que as próprias condiçôes dele. De modo que, ainda seguindo o intérprete italiano e desta vez citando suas próprias palavras: "o ser exclui, sem dúvida, o passado enquanto implica destruição e o futuro enquanto implica movimento, mas não exclui o antes e o depois da permanência igual e constante de sua realidade" 16 .

Melisso de Samos explicita a ideia de infinito implícita em Parmênides - "nada que tem princípio e fim é eterno ou infinito" (frag. 4) -, bem como a ideia de que aquilo que é infinito deve necessariamente ser uno: "se fosse (infinito), seria um; pois, se fossem dois, não poderiam ser infinitos, mas teriam limites um com o outro" (frag. 6). Com estes elementos, ele pode afirmar categoricamente o ser que "sempre era o que era e sempre será" (frag. 1) e que "uma vez, portanto, que não veio a ser, é, e sempre era, e sempre será e não tem princípio, nem fim, mas é infinito" (frag. 2). Ao contrário de Parmênides, que parece fundamentar a sua concepção do eterno por meio da afirmação ontológica do instante presente, Melisso parece alicerçar a sua própria noção mediante a afirmação da infinitude do ser. Não é pelo fato do "ser" existir verdadeiramen-

16 Mondolfo, p. 100. 
te apenas neste agora $(n \hat{y} n)$ que ele é dito eterno, mas sim por estender-se infinitamente em direção ao passado e ao futuro (o emprego de Melisso do advérbio aeí parece anular o sentido temporal das formas verbais a ele adjuntas).

Caberia mencionar ainda uma reflexão sobre o tempo que permaneceu marginal às ideias cíclicas do tempo desenvolvidas por diversos filósofos gregos. Esta posição é representada pelos atomistas, em especial por Leucipo e Demócrito. Estes pensadores acreditam que "nada se engendra ao acaso, mas tudo a partir de razão e por necessidade" (Leucipo, frag.2). Eles parecem postular, portanto, uma infinita cadeia causal dos eventos, tanto na direção pretérita quanto na futura, afastando-se, assim, da concepção cíclica da eternidade mais usual entre os filósofos gregos.

Em Platão e Aristóteles, como já dissemos, a cisão entre o tempo e a eternidade, iniciada por Parmênides, parece se completar. Comecemos a nossa breve análise, desses dois baluartes da filosofia ocidental, por Platão.

No Timeu, Platão separa claramente uma dimensão sujeita às mutações e ao devir de uma outra imutável e eterna. Acerca da "essência eterna" (aídion ousían) pode-se dizer, segundo Platão, "que ela foi, é e será, embora, de acordo com a razão verdadeira, somente o é lhe convém; o foi e o será, ao contrário, é adequado dizer da geração que procede no tempo: com efeito, ambos são movimentos (kinéseis)" (Timeu, 37E-38A). Ao afirmar o eterno por meio do presente do verbo ser, Platão recai no mesmo problema de Parmênides, ou seja, "a eterna presencialidade tende a converter-se 
em perene duração que implica, em si, uma referência tácita à sucessão temporal"17. Isto se evidencia pelo uso ambíguo do advérbio aeí ("sempre"), indicando, por um lado, a permanência dos seres eternos (Timeu, 27D: "o que é sempre, não tendo nascimento") e, por outro, a incessante geração dos entes sujeitos ao devir (Timeu, 27D: "o que sempre está em devir e nunca é"). Graças a esta estrutura analógica entre o "sempre existente" (aè̀ ón) e o "sempre deveniente" (aè ginómenon), porém, Platão pode formular a sua definição do tempo, hoje clássica, como "uma imagem eterna (aiónion eikóna), que procede segundo o número, da eternidade (aîônos) que permanece na unidade" (Timeu, 37D ${ }^{18}$. Nessa concepção mítica da produção do tempo por obra do Demiurgo, encontramos indubitavelmente manifesta uma das características principais da filosofia platônica, a saber, a da mediação que nela os números parecem estabelecer entre o Um e o múltiplo. Na definição do tempo acima referida, Platão faz questão de explicitar, por exemplo, que o tempo não é uma imagem qualquer da eternidade, mas sim que é a imagem da eternidade "que procede segundo o número". O número, por conseguinte, instaura a mediação entre "a eternidade que permanece na unidade" e a multiplicidade dos entes do mundo natural.

17 Mondolfo, pp. 107-108.

18 Para uma análise exaustiva dessa célebre definição de Platão cf. R. Brague, "Pour en finir avec 'le temps, image imobile de l'éternité (Platon, Timée, 37d)", in: R. Brague, Du temps chez Platon et Aristote. Quatre études, PUF, Paris, 1982, p.11-71. 
Aristóteles, por seu lado, investiga a essência do tempo e do instante especialmente nos capítulos dez a catorze do quarto livro da Física, obra na qual se dedica ao estudo dos entes naturais, ou seja, dos entes que possuem em si mesmos o princípio de seu movimento e repouso. O tempo, bem como o lugar e o vazio, são as condições (lógicas e ontológicas) possibilitadoras da existência e da possibilidade de se pensar o movimento e, consequentemente, o tempo. Este, segundo o Estagirita, deve ser sempre pensado em relação ao agora, pois sem o agora não haveria tempo (Phys. IV 11, 219b33-220a1). O tempo, contudo, não deve ser concebido como se fosse constituído de agoras; esses não são partes do tempo, mas apenas os limites do mesmo. De modo que são necessários ao menos dois agoras (Phys. IV 11, 220a14-16), identificados por uma alma capaz de numerá-los um como o anterior e o outro como o posterior, a fim de delimitar um intervalo de tempo. E será precisamente por meio desse intervalo, assumido como uma unidade que a alma humana poderá então quantificar o deslocamento cinético de um corpo móvel qualquer. É importante ressaltar que para Aristóteles a unidade deve ser sempre congênere àquilo por ela mensurado, daí ser fundamental medir o tempo por meio de uma unidade de tempo e não através dos agoras (Phys. IV 11, 223b13-14). Destas reflexões esquematicamente aludidas resulta então a clássica definição do tempo proposta pelo Estagirita como "número do movimento segundo o anteriorposterior” (Phys. IV 14, 219b1-2). 
Ao final da Física (no livro VIII) e na Metafisica (no livro $\Lambda$ ), Aristóteles defende, para fundamentar o movimento, a existência de um "Movente imóvel" que, entretanto - ao contrário do Demiurgo platônico apresentado no Timeu - permanece completamente imaculado por qualquer tipo de movimento, dado que ele não parece atuar como causa eficiente do mundo, mas precipuamente como causa final, e isso em virtude de sua própria existência. Em Aristóteles, portanto, completar-se-ia, segundo alguns exegetas, o processo de separação entre tempo e eternidade. Para o Estagirita, o movimento e, por conseguinte, o tempo existem apenas para os entes físicos corruptíveis. A eternidade, ao contrário, é uma prerrogativa, tanto dos entes físicos incorruptíveis quanto do "Movente imóvel" (Metaph., 1073a3-4). De fato, só este último pode ser dito em sentido estrito plenamente imóvel.

Após termos exposto de modo geral e muito esquemático as diferentes concepçōes do tempo defendidas pelos filósofos gregos, é oportuno relacioná-las com as ideias que os autores trágicos deixaram transparecer em suas obras acerca do fenômeno temporal tal como ele nos acomete em nossas vidas. Por meio dessa comparação podemos constatar que, apesar das divergências internas, os filósofos, principalmente Platão e Aristóteles, dando sequência à tradição eleática, procuraram estabelecer a distinção entre a dimensão temporal e a eterna. Com efeito, de acordo com Platão, acerca dos entes naturais só pode haver opinião (dóxa) propriamente dita; a verdadeira ciência (epistémę), ao contrário, deve ocupar-se apenas dos entes eternos. E 
mesmo Aristóteles, que procura estabelecer a cientificidade do estudo da natureza, não deixa de priorizar o movimento circular dentre todos os tipos de movimento, na medida em que nele o início e o fim se encontram reunidos. Eis a razão da supervalorização do movimento dos astros por ambos esses pensadores: esse movimento é concebido pelos dois como sendo um movimento circular e, portanto, como sendo um movimento perfeito.

Os três maiores poetas trágicos, ou seja, Ésquilo, Sófocles e Eurípides, por outro lado, procuravam sobretudo explicitar por meio de suas obras os efeitos deletérios e irreversíveis do tempo na vida dos homens. Em outras palavras: eles trabalhavam, ainda que sem estarem cônscios deste fato, com uma concepção que poderíamos caracterizar de linear do tempo.

Sem cairmos em um esquema simplista, acreditamos poder dizer que a ênfase de Platão e Aristóteles, por exemplo, recaía antes sobre o estudo da relação tempo/transcendência, enquanto os autores dramáticos, em suas tragédias, enfatizaram preferencialmente a relação tempo/imanência. Assim se, por um lado, os filósofos procuravam escapar, por meio da ciência verdadeira, aos efeitos destrutivos do tempo - sem, contudo, negar-lhe uma existência relativa (afastandose assim da negação radical do tempo proposta por Parmênides, ao menos tal como eles o leram e entenderam) - os trágicos, por outro lado, procuravam explicitar em seus dramas esses mesmos efeitos nos meandros tortuosos e finitos da vida humana. 
Por fim, resta-nos averiguar até que ponto as nossas concepçóes hodiernas do tempo são comparáveis, e em caso afirmativo em que medida o são, com as diferentes representaçóes do tempo até o final da Era Clássica. Como dissemos no início deste artigo, não devemos acreditar ingenuamente em uma univocidade plena entre os nossos conceitos e os de outra civilização ou época histórica. Todavia, tampouco devemos supor haver uma diferença radical e intransponível entre esses conceitos ou essas épocas históricas e o nosso modus vivendi hodierno. A fim de ilustrar esse paralelismo, vejamos alguns aspectos interessantes de nossa linguagem usual.

Uma particularidade do substantivo "tempo" no vernáculo, por exemplo, é que ele amalgama, dentre outros, três diferentes significados, a saber: 1) a sucessão dos anos, dias, horas, etc., 2) as condições meteorológicas e 3) a flexão indicativa do momento a que se refere o estado ou ação verbal. A justaposiçãa desses três estratos semânticos era, entretanto, completamente alheia aos gregos. Destes significados eles só conheciam o primeiro. Todavia, o nosso termo "tempo" preserva ainda um outro sentido que os gregos também atribuíam a khrónos, a saber, o de "ocasião ou momento oportuno" (a sentença "ainda é tempo de reconsiderar a sua decisão" possui, por exemplo, este significado). As locuções adverbiais "a tempo" e "em tempo" também expressam a mesma ideia. Assim, quem chegou a tempo ou em tempo, chegou no momento oportuno. O substantivo "contratempo" é particularmente interessante, pois parece sugerir que 
o tempo possui um curso natural que é obstaculizado por algum evento ou circunstância imprevisto. A locução adverbial "a contratempo" aponta na mesma direção e é um sinônimo de "fora de tempo" que, por sua vez, opõe-se simetricamente às locuções adverbiais "a tempo" e "em tempo".

Ao analisarmos mais cuidadosamente os substantivos "dia" e "hora" em nosso idioma percebemos que também eles encerram resquícios de uma concepção qualitativa do tempo. Isso é facilmente depreendido da análise de expressóes como "cada qual tem o seu dia", "seu dia chegará" ou "um dia é da caça, o outro do caçador". No caso do substantivo "hora” ocorre o mesmo ao usarmos, por exemplo, expressóes como: "antes da hora", "é chegada a hora”, "em boa/má hora” ou "fora de hora".

A análise das expressões acima referidas, relativas ao "tempo", ao "dia" e à "hora", parece, portanto, revelar certa analogia com a concepção temporal presente em Homero e em Hesíodo, na medida em que, tanto esses autores quanto essas expressóes do nosso idioma, parecem enfatizar o caráter eminentemente qualitativo do tempo. A esta concepção qualitativa subjaz a crença de que o tempo, o dia ou a hora não são meros meios abstratos e homogêneos no qual ocorrem os eventos de nosso mundo, mas sim que, eles mesmos, são forças ativas que influenciam decisivamente o desenrolar dos próprios acontecimentos, quer de modo favorável quer desfavorável. Eles são, em suma, expressões ou manifestações do destino pessoal. 
Deste modo, podemos constatar que, apesar das diferenças existentes entre as nossas concepções sobre o tempo e aquelas presentes no mundo grego podemos, ainda assim, detectar alguns significativos pontos de contato entre ambas por meio de alguns aspectos preservados, como acabamos de ver, no uso coloquial e cotidiano de nossa língua. 
(Página deixada propositadamente em branco) 


\section{BIBLIOGRAFIA}

Brague, R. Du temps chez Platon et Aristote, Paris, PUF, 1982.

Colli, G. La Sapienza Greca, 3vls., Milano: Adelphi, 1992.

Fränkel, H. "Die Zeitauffassung in der frühgriechischen Literatur”, in: H. Fränkel, Wege und Formen frühgriechischen Denkens, München: Beck, 1955.

Frère, J. "La dialectique du temps selon Platon et Aristote", in: Platon et Aristote. Dialectique et Métaphysique, Brussels: Ousia, 2004.

Lloyd, G.E.R. "O tempo no pensamento grego", in: As Culturas e o Tempo. Estudos reunidos pela UNESCO, Petrópolis: Vozes/Edusp, 1975.

Mondolfo, R. El Infinito en el Pensamiento de la Antigüedad Clássica, Buenos Aires: Ediciones Imán, 1952.

Onians, R.B. The Origins of European Thought about the Body, the Mind, the Soul, the World, Time and Fate, Cambridge: Cambridge University Press, 1988. 
Romilly, J. Le Temps dans la Tragédie Grecque, Paris: Vrin, 1971.

Vernant, J.-P. Mito \& Pensamento entre os Gregos, Rio de Janeiro: Paz e Terra, 1990. 


\section{O SÚBITO (EXAÍPHNES) EM PLATÃO}

Presente texto insere-se em uma pesquisa mais abrangente que pretendemos levar a cabo algum dia e que teria por objetivo estudar algumas das figuras do tempo que aparecem ao longo dos diálogos de Platão, a saber, aión, kairós e exaíphnes. Seguimos aqui algumas considerações de Jean-François Mattéi expostas em um breve, mas denso artigo intitulado precisamente "Les figures du temps chez Platon"19. Nesse texto, o autor opõe-se tanto a uma interpretação neoplatônica dos diálogos de Platão, quanto a uma abordagem anti-platônica dos mesmos (tal como a elaborada, por exemplo, por Nietzsche) na medida em que ambas atribuem ao pensamento de Platão uma preocupação quase que exclusiva com a transcendência e com

19 Cf. L. Couloubaritsis/ J.J. Wunenberger, Les Figures du Temps, Presses Universitaires de Strasbourg: Strasbourg, 1997. 
a eternidade, em detrimento da finitude e do tempo, valorizando esse procedimento quer de modo positivo (no caso da interpretação neoplatônica) quer de modo negativo (no caso de Nietzsche). Todavia, como Mattéi assinala enfaticamente: "A filosofia de Platão é uma filosofia do tempo e não da eternidade" ${ }^{20}$. Ele explica mais detalhadamente, a seguir, que isso ocorre porque a alma se conhece a si mesma no tempo, mas se relaciona mutuamente com os planos do sensível e do inteligível. Por isso, segundo o exegeta, essa discussão sobre o tempo em suas múltiplas faces e figuras aparece sempre nos diálogos platônicos no âmbito do confronto alma/mundo, como, por exemplo, na discussão sobre o nascimento do mundo, da reminiscência ou do julgamento derradeiro da alma. Além disso, Mattéi nos adverte para o fato de que essa discussão se apresenta antes como uma demonstração simbólica do que como uma demonstração racional e essa é a razão pela qual ele adota precisamente a denominação de figuras e não de conceitos do tempo. Em linhas gerais, devo observar que essa abordagem me parece rica e fecunda e que pretendo explorar mais detidamente neste breve texto apenas uma dessas figuras por ele propostas, qual seja, exaíphnes. Todavia, creio que uma análise mais detalhada dessa questão do tempo e das suas figuras na obra de Platão demandaria, além da investigação sobre as três figuras do tempo acima mencionadas, a inclusão de um mapeamento preciso dos usos que Platão

20 Ibid., p. 30. 
faz de ao menos dois outros termos não mencionados por Mattéi, a saber, khrónos e $n \hat{y} n$.

Antes, porém, de nos aprofundarmos na análise da ocorrência do termo exaîphnẹs em Platão ${ }^{21}$, será útil aludir ao fato, bastante frequente no que diz respeito a Platão, que essa palavra, no caso um advérbio temporal, não foi uma criação de nosso filósofo, pois desde Homero e Píndaro ela já era empregada com o significado de "subitamente, repentinamente". O que encontraremos em Platão, portanto, será como de costume $e^{22}$, a resignificação desse advérbio no interior de sua filosofia e é precisamente esse processo de reinscrição filosófica de um termo coloquial que tentaremos descrever em breves passos ao longo desse também breve texto.

Podemos dividir a ocorrência do advérbio exaíphnes na obra de Platão em dois tipos de uso: um uso trivial e um uso mais filosófico, ou seja, um uso que deno-

21 Sobre esse conceito recomendamos particularmente a leitura dos seguintes artigos: W. Beierwaltes, " $E \xi \alpha \iota \varphi \nu \eta \zeta$ oder: die Paradoxie des Augenblicks”, Philosophisches Jahrbuch, v.74, 1966/67, L. Brisson, "L'instant, Le temps, et l'éternité dans le Parménide, Dialogue, v.IX, 1970, n.3 e C. Link, "Der Augenblick. Das Problem des platonischen Zeitverständnisses”, in: Die Erfahrung der Zeit. Gedenkschrift für Georg Picht, Hrsg. C. Link, Klett-Cotta: Stuttgart, 1984.

22 Cf. o ainda atual opúsculo de Kurt Von Fritz, Philosophie und sprachlicher Ausdruck bei Demokrit, Plato und Aristoteles, Wissenschaftliche Buchgesellschaft: Darmstadt, 1966 (Durchgesehener reprographischer Nachdruck der Ausgabe New York, Leipzig, Paris, London 1938). 
ta uma apropriação explicitamente filosófica do conteúdo coloquial presente no advérbio temporal aqui em questão. Além disso, e talvez essa seja a ocorrência mais importante desse vocábulo nos diálogos, devemos mencionar a substantivização do mesmo que ocorre uma única vez na obra platônica, a saber, no diálogo Parmênides.

Em seguida, procuraremos ilustrar com algumas passagens dos diálogos platônicos o uso que Platão faz desse advérbio antes de entrarmos propriamente na análise do significado do mesmo, o que só ocorre, como veremos, no diálogo tardio Parmênides.

$\mathrm{O}$ advérbio exaíphnes aparece ao todo 34 vezes nos diálogos, segundo o léxico de Brandwood ${ }^{23}$, sendo que em poucas linhas do Parmênides ele é empregado quatro vezes, o que, por si só, já seria suficiente para nos chamar a atenção de modo especial para a importância desse diálogo para a compreensão desse termo. Entretanto, muitas das ocorrências do vocábulo em questão nos diálogos, como veremos, nada mais fazem do que refletir o uso coloquial de um advérbio temporal conhecido há muito pelos gregos. Outras passagens, contudo, assinalam que realmente estamos diante de uma apropriação filosófica do mesmo. Vejamos então alguns desses passos.

No Crátilo, por exemplo, quando Sócrates investiga juntamente com Hermógenes o problema da de-

23 Cf. L. Brandwood, A Word Index to Plato, W.S. Maney \& Son Limited: Leeds, 1976. 
nominação, este em um determinado momento do diálogo reponde àquele que "talvez não seja fácil ser convencido tão repentinamente" (Crat. 391 A: is $\underline{\text { os }}$ méntoi ou rhaídión estin hoútos exaiphnes peisthênai). Além disso, usando o vocábulo de modo mais convencional algumas páginas mais adiante no diálogo, mais precisamente quando Sócrates relata uma de suas, para os critérios de hoje, fantasiosas etimologias, ele alude ao fato que poderia parecer excessivo a alguém que o "escutasse repentinamente" (Crat. 396 B: akoúsanti exaiphnes), de acreditar que Zeus fosse filho de Kronos, mas levando em conta algumas outras etimologias que ele expõe a seguir, isso seria facilmente compreensível.

No Banquete, encontramos uma passagem exemplar para exprimir mais exatamente o que seria o sentido corriqueiro desse advérbio. Ao final dos discursos sobre éros proferidos pelos convivas, irrompe Alcebíades embriagado. Após começar a falar, ele descobre Sócrates que, na verdade, estava diante dele o tempo todo, mas de quem ele ainda não havia se apercebido. Então, após algumas exclamações expressivas de sua surpresa por esse imprevisto encontro, ele diz a Sócrates: "como de costume tu apareces repentinamente onde eu menos acreditaria que tu estivesses" (Symp. 213 C: hósper eiótheis exaiphnes anaphainesthai hópou egò ó $i$ men hékistá se ésesthai). Essa passagem é exemplar a fim de ilustrar o sentido trivial de exaiphnes, pois nela todo conteúdo de imprevisibilidade e instantaneidade inerentes ao vocábulo estão presentes. Trata-se, portanto, de uma aparição súbita, inesperada e imprevisível. 
Note-se, contudo, que essa aparição pode ocorrer em relação a algo ou alguém já presente, mas despercebido. Como no exemplo mencionado, Sócrates já estava lá diante de Alcebíades o tempo todo, apenas ainda não havia sido notado pelo mesmo. Foi esse ato de percepção de Alcebíades então que ocorreu de modo imprevisível e repentino e é precisamente isso que caracteriza o termo exaíphnes, ou seja, uma ocorrência súbita e inesperada.

Vejamos, a seguir, o que significa o uso mais propriamente filosófico desse termo. É fundamental observar que a carga semântica do vocábulo continua sendo a mesma, apenas o uso desse advérbio é que parece ser claramente circunscrito, no caso do uso filosófico, a um determinado âmbito e esse uso, como veremos, serve precisamente para demarcar a passagem de um plano ou nível de conhecimento para outro. Em outras palavras: temos um uso, por assim dizer, epistemológico de exaíphnes. Vejamos alguns exemplos.

Comecemos pelo próprio Banquete. Ao Platão descrever, no discurso de Diotima, a ascensão do amante em direção ao Belo em si, ele nos diz que este, após galgar várias etapas intermediárias, "subitamente contemplará um belo, maravilhoso por natureza” (Symp. $210 \mathrm{E}$ : exaiphnes katópsetai ti thaumastòn tèn phýsin kalón). Outro exemplo pode ser acrescentado ao considerarmos um passo da Carta VII onde Platão afirma que "os princípios primeiros da natureza" (344 D) não podem de modo algum ser ensinados "como os demais conhecimentos" (hôs álla mathémata), "mas, a partir de muita freqüentação e convivência com a 
coisa mesma, esta subitamente se gera na alma, como a luz que se acende de uma faísca e se alimenta de si mesma" (Epist. VII 341 C-D: all' ek pollês synousías gignoménes perì tò prâgma autò kaì tôu syzên exaíphnes, hoîon apò pyròs pẹdésantos exaphthèn phôs, en têi $i$ psykhệi genómenon autò heautò éde tréphei). Vemos, com clare$\mathrm{za}$, nesses dois passos que exaíphnes indica uma ruptura, um hiato no plano ou nível de conhecimento que ocorre repentina e inesperadamente. Note-se, entretanto, que isso só acontece após um longo percurso. Esse "salto epistemológico" é como que o resultado produzido subitamente depois de longa e paciente frequentação e exercitação. Mais duas passagens da República vem corroborar esse uso. O primeiro passo indica a mesma direção epistemológica, a saber, do sensível ao inteligível, que se depreende do passo do Banquete acima citado. O contexto é a libertação do prisioneiro da caverna. Esse processo é descrito como ocorrendo repentinamente. Assim, um prisioneiro seria libertado e forçado a se erguer "subitamente" (exaiphnes) e, em seguida, a volver o pescoço, a caminhar e a soerguer os olhos em direção à luz (cf. Rep. VII 515 C). A segunda passagem desse mesmo diálogo é especialmente importante, pois assinala que a direção em que se faz essa mudança de plano ou nível de conhecimento não é fundamental para caracterizálo, mas sim a instantaneidade do processo. De modo que, como podemos ler logo a seguir, se o homem libertado voltar a retomar seu lugar na caverna, isso ocorrerá mais uma vez "subitamente" (exaiphnes). Ele teria seus olhos cegados "subitamente" (exaiphnes) ao 
vir da claridade do Sol para a escuridão da caverna (cf. Rep. VII 516 E). Vê-se, portanto, que em todas essas ocorrências essa transição se dá sem continuidade, ela é como que um salto que supera inesperada e instantaneamente um plano ou nível de conhecimento em direção a outro. Do sensível ao inteligível ou do inteligível ao sensível, ou ainda, no caso da sétima carta, de um tipo de conhecimento ensinável para outro que só pode ser adquirido pela frequentação e convivência (se quisermos esclarecer anacronicamente esse passo, poderíamos dizer, nos termos de Kierkegaard, que um conhecimento de ordem ético-religioso não pode ser objeto de uma comunicação de saber, mas apenas de uma comunicação de poder, devendo, portanto, ser comunicado de modo indireto $\left.{ }^{24}\right)$.

Por fim, resta-nos a difícil, mas fundamental tarefa de nos referirmos ao Parmênides. Como já dissemos inicialmente, esse diálogo é o único lugar onde Platão substancializa o advérbio exaíphnes. Mas, mais importante que isso, essa é a única vez em que Platão define esse termo. Além disso, convém assinalar também que a ocorrência desse termo no interior do diálogo desempenha uma função análoga àquela expressa pelo conteúdo semântico do mesmo, ou seja, ele constitui o eixo de articulação das diversas hipóteses expostas ao longo da segunda parte do diálogo ao conectar expli-

24 Cf. S. Kierkegaard, La dialettica della comunicazione ética ed éticoreligiosa, in: Studi kierkegaardiani com um inédito di S. Kierkegaard, a cura di C. Fabro, Morcelliana: Brescia, 1957. 
citamente a primeira com a segunda hipótese (essa interpretação mais tradicional, que se apóia em exegeses neoplatônicas, é atualmente contestada por L. Brisson, mas, em minha opinião, o modelo interpretativo mais convencional ainda parece ser mais fecundo do que as novas considerações, de cunho mais analítico, do erudito e renomado pesquisador canadense de língua francesa). O que está por trás dessa densa estratégia conceitual de Platão, parece-me, é a ênfase que o mesmo concede à importância dos intermediários em sua filosofia. E o termo exaíphnes é por ele definido como sendo um intermediário, um metaxý, como nos esclarece algumas passagens de sua obra (cf. Parm. 156 D, 157 A). A natureza de um metaxý é precisamente a de ser um terceiro termo entre dois polos (cf. Parm. 155 E, Timeu 48 E, 49 A e 52 A), tal como no Parmênides, por exemplo, a terceira hipótese estabelece a mediação entre as duas primeiras.

O que diz então a definição de exaíphnes? Ela afirma que "o súbito parece significar algo como uma mudança a partir de uma coisa em direção a outra. Com efeito, não é do que está em repouso quando ainda em repouso que surge a mudança [para o movimento], nem do movimento enquanto ainda se move surge a mudança [para o repouso]. Mas o próprio súbito, essa estranha natureza, é um intermediário entre o movimento e o repouso, não sendo em tempo algum, e é para ele e a partir dele que o móvel muda para o repouso e o que está em repouso para o que se move" (Parm. 156 D-E: Tò gàr exaiphnes toiónde ti éoike semainen, hos ex ekeinou metabállon eis hekáteron. Ou 
gàr ék ge tồ hestánai hestôtos éti metabállei, oud' ek tês kinéseos kinouménes éti metabállei. Allá he exaíphnes haúte phýsis átopós tis enkáthetai metaxy tês kinéseós te kaì stáseọs, en khrónoi oudenì oûsa, kaì eis taúten dè kaì ek taútes tó te kinoúmenon metabállei epì tò hestòs epì tó kineîsthai). Vê-se, por conseguinte, que o súbito é um intermediário que ao não ser nenhum dos polos em oposição permite estabelecer a mediação entre os mesmos. Atente-se para o fato de que esse terceiro não é simplesmente a síntese entre, digamos, o tempo e a eternidade, mas sim o intermediário fora do lugar (átopos) e do tempo que possibilita a articulação entre ambos. Igualmente encontramos outro metaxý com essa mesma função no Timeu, a khóra. As relações entre esses termos infelizmente escapam ao âmbito do presente texto.

Gostaria de lembrar que o sentido trivial de exaiphnes ocorria, por exemplo, ao Alcebíades referirse ao modo como Sócrates costumava aparecer diante dele. E isso é particularmente interessante, pois em toda a Apologia Sócrates é caracterizado como átopos, estranho (mais literalmente: sem lugar) exatamente da mesma forma que o súbito é caracterizado no Parmênides, a saber, como átopos. Seria isso uma mera coincidência ou seria um indício de que a própria figura de Sócrates deveria ser entendida como mais um representante da classe dos intermediários? Se fosse assim, poderíamos compreender então o porquê da extrema dificuldade em conceituá-lo, bem como a razão de ser de sua ambiguidade constitutiva e de seu papel fundamental em diversos diálogos. Talvez o mais profícuo, mas segura- 
mente o mais difícil quando lemos Platão, seja analisar os intermediários e não nos apegarmos excessivamente a um dos polos do pretenso (e falso) dualismo platônico. Platão parece estar, na verdade, muito mais interessado nos metaxý do que em uma transcendência radical. Mas devido à dificuldade em conceituar ou definir o que não é nem uma coisa nem o seu oposto, não teria sido uma estratégia interessante e perspicaz de nosso autor recorrer aos mitos, dado que a linguagem simbólica permite a coabitação de opostos, sem incorrer em uma contradição lógica?

Por fim, gostaria apenas de assinalar um curioso ponto de convergência entre exaíphnes e a khóra que também é mencionado por Jean-François Mattéi: o sonho (cf. Parm. 164 D e Timeu 52 B). Investigar essa relação, entretanto, nos levaria mais longe, como já dissemos em relação à khrónos, do que podemos ir neste breve texto. 
(Página deixada propositadamente em branco) 


\section{BIBLIOGRAFIA RESUMIDA}

\section{BIBLIOGRAFIA PRIMÁRIA:}

Platonis Opera, recognovit brevique adnotatione critica instrvxit Ioannes Burnet, Tomes I-V. Oxford : Clarendon Press, 1900-1907.

\section{BIBLIOGRAFIA SECUNDÁRIA:}

W. Beierwaltes, " $\mathrm{E} \xi \alpha \iota \varphi \nu \eta \varsigma$ oder: die Paradoxie des Augenblicks”, Philosophisches Jahrbuch, v.74, 1966/67.

L. Brandwood, A Word Index to Plato, W.S. Maney \& Son Limited: Leeds, 1976.

L. Brisson, "L'instant, Le temps, et l'éternité dans le Parménide, Dialogue, v.IX, 1970, n.3.

L. Couloubaritsis/ J.J. Wunenberger, Les Figures du Temps, Presses Universitaires de Strasbourg: Strasbourg, 1997. 
C. Link, "Der Augenblick. Das Problem des platonischen Zeitverständnisses”, in: Die Erfahrung der Zeit. Gedenkschrift für Georg Picht, Hrsg. C. Link, Klett-Cotta: Stuttgart, 1984.

Kurt Von Fritz, Philosophie und sprachlicher Ausdruck bei Demokrit, Plato und Aristoteles, Wissenschaftliche Buchgesellschaft: Darmstadt, 1966 (Durchgesehener reprographischer Nachdruck der Ausgabe New York, Leipzig, Paris, London 1938). 


\title{
TEMPO E LIBERDADE
}

DO FINALISMO ARISTOTÉLICO AO

FATALISMO ESTÓICO

\begin{abstract}
Objetivo deste texto é o de estudar comparativamente as concepções peripatéticas e estóicas acerca do tempo e da causalidade, procurando analisar detalhadamente em que medida essas ideias divergentes acerca da estrutura física do mundo produziram diferentes resultados na reflexão lógica e ética desenvolvida por essas duas importantes escolas filosóficas do pensamento antigo. Cabe ressaltar que, por um lado, ao falarmos em uma concepção peripatética, pensamos não só em Aristóteles, mas também em seu mais famoso comentador da Antiguidade, Alexandre de Afrodísia (dado que este polemizou diretamente com os estóicos acerca de várias questóes, especialmente a respeito da doutrina estóica sobre o destino) e, por outro, que quando nos referimos ao estoicismo, pensamos principal e primordialmente no estoicismo helenístico e não no estoicismo da era imperial.
\end{abstract}


Este texto deverá nortear-se, pois, seguindo a divisão tripartite da filosofia proposta pelos estóicos, a saber, a que estabelece três partes constitutivas da filosofia, a saber, a física, a ética e a lógica. Esta divisão que, segundo o testemunho de Diógenes Laércio, prevaleceu desde o fundador da Stoa, Zenão, até um dos últimos representantes da vertente helenística da Escola, Posidônio (cf. SVF II, 37, 38), tinha uma intenção claramente didática, pois os estóicos, ao contrário de separá-las, trabalhavam justamente na inter-relação constitutiva e condicionante entre essas três partes da filosofia. Atentemos aqui para o fato de que, a diferença dos estóicos, em Aristóteles a lógica nunca foi propriamente considerada como sendo uma parte da filosofia, mas apenas como uma ferramenta propedêutica para a mesma. Este, como se sabe, foi o modo como Andrônico de Rodes a compreendeu, como se depreende da ordenação dos escritos aristotélicos que ele empreendeu, mas seguramente este não foi e não precisa ser o único modo de situar a lógica no interior do pensamento aristotélico ${ }^{25}$.

O cerne de nossa investigação será, portanto, o de analisar tanto em Aristóteles quanto nos estóicos: a) o tratamento concedido ao tempo e à causalidade no âmbito da física, b) o problema lógico de saber se é possível ou não fazer no presente uma asserção verdadeira ou falsa relativa a um acontecimento futuro não

25 Cf. L. Rossetti, Introduzione alla filosofia antica.Premesse filosofiche ed altri ferri del mestiere, Levante Editori: Bari, 1998. 
necessário e, por fim, c) a questão da legitimidade ou ilegitimidade de imputar aos homens a responsabilidade pelas suas ações. Essa tríplice problemática converge para a discussão acerca do destino (heimarméne), um tema que na filosofia pós-aristotélica tornou-se, como se sabe, central no debate filosófico.

Este texto originou-se primeiramente a partir de um estudo minucioso dos diversos sentidos do tempo em Aristóteles ${ }^{26}$, que nos permitiu perceber conexões normalmente pouco trabalhadas e/ou analisadas entre as concepções lógicas, físicas e éticas do Estagirita. Obviamente, estes nexos não indicam uma mera continuidade linear entre essas três esferas, antes eles assinalam apenas as analogias existentes entre elas, razão pela qual, embora o próprio Aristóteles jamais tenha empreendido uma análise dos múltiplos sentidos do tempo em sua obra, é possível e mesmo proveitoso estabelecer essa comparação. O que nos motivou, posteriormente, a estabelecer um confronto com o estoicismo foi o fato de que os principais representantes da era helenística dessa corrente filosófica, a saber, Zenão, Cleanto, Crisipo, Panécio e Posidônio, postulavam, ao contrário do que ocorria em Aristóteles, uma estreita continuidade entre esses distintos planos de análise. Algumas questóes a esse respeito se colocaram para nós: Como teria se dado essa passagem de uma teoria finalista e plurívoca em Aristóteles para uma doutrina

26 Cf. F. R. Puente, Os sentidos do tempo em Aristóteles, Loyola/Fapesp: São Paulo, 2001. 
determinista e unívoca nos estóicos? Por que a reflexão filosófica teria posto de lado uma determinada doutrina acerca da causalidade e afirmado uma outra? Com que consequências para a ética e para a lógica? Essas perguntas, dentre outras, nos motivaram a estudar os estóicos helênicos em busca de um maior entendimento sobre suas opções filosóficas. O presente texto visa, por conseguinte, propor uma análise comparativa das doutrinas estóicas com as de Aristóteles e dos peripatéticos, a fim de tentar compreender melhor as suas diferenças.

Caracterizemos, pois, mais apuradamente as posiçôes de Aristóteles e dos estóicos por meio de um confronto entre as suas respectivas teses.

Não é possível isolar, como já dissemos, as ideias físicas e, diríamos hoje, metafísicas de Aristóteles de suas inovações lógicas e de suas concepções éticas. A filosofia aristotélica postula haver uma divisão fundamental entre uma essência imóvel, por um lado, e essências móveis por outro. Este modelo dicotômico, contudo, parece ser, na verdade, um modelo tricotômico pelo fato de as essências móveis subdividirem-se, por sua vez, em corruptíveis e eternas, mas, de fato, a divisão mais própria do pensamento aristotélico parece ser aquela em que as essências são classificadas como imóveis e móveis (cf. Phys. II 6, $198 \mathrm{a}_{30-31}$ ), como sensíveis e imóvel (cf. Metaph. $\Lambda 1,1069 \mathrm{a}_{30-33}$ ), ou ainda, como físicas e imóvel (cf. Metaph. $\Lambda \quad 6,1071 \mathrm{~b}_{3-4}$ ). A essa divisão dual dos tipos de essência corresponde uma análoga divisão das partes da filosofia, a saber, a filosofia primeira (que depois de Andrônico de Rodes 
nós denominamos de metafísica) e a filosofia segunda (a física) (cf. Metaph. Г 2, $\left.1004 \mathrm{a}_{2-3}\right)^{27}$. A filosofia segunda, a diferença do projeto filosófico de Platão, busca ser efetivamente uma ciência do mundo físico, ainda que não tenha por objetivo encontrar um princípio de inteligibilidade geométrico ou matemático nos entes físicos (como ocorria no Timeu, embora esse fosse, como seu próprio autor nos adverte, apenas um relato mítico e não um discurso propriamente científico sobre a criação do mundo), mas sim analisá-los enquanto capazes de movimento e repouso. Por conseguinte, o paradigma utilizado pelo Estagirita para pensar os entes físicos, como se sabe, não é propriamente o matemático (embora uma análise matemática esteja presente na Física, como as investigações sobre o infinito e o contínuo mostram com clareza), como no Timeu, mas sim o artístico ou técnico, pois, segundo Aristóteles, se a arte imita a natureza e se o artesão ou o técnico deve conhecer tanto a matéria quanto a forma, então a meta do físico seria também a de conhecer ambos conceitos - matéria e forma (cf. Phys. II 2, $194 \mathrm{a}_{21-27}$ ). A compreensão do que é um ente físico, ou seja, de um ente que possui em si mesmo a causa de seu movimento e repouso, é adquirida então quando se está apto a entender a relação entre meio e fim existente entre a matéria e a forma. Todavia, há uma diferença entre a atitude do "artista/técnico" e a do "físico" ante

27 Cf. Ph. Merlan, From Platonism to Neoplatonism, Martinus Nijhoff: The Hague, 1975 (especialmente o terceiro capítulo). 
a natureza: o primeiro quer dominá-la e governá-la, já o segundo mantém uma postura mais especulativa, mais teórica face à natureza (cf. Phys. II 2, 194 b) . A filosofia de Aristóteles pode ser propriamente caracterizada como uma doutrina da forma (eîdos). Esta doutrina deve ser entendida, portanto, em contraposição à teoria das Ideias ou Formas (eídẹ) de Platão, o que não quer dizer pura e simplesmente que o Estagirita rejeite totalmente a posição platônica, mas antes que ele resignificou e renovou as teses filosóficas de seu mestre, conservando deste modo aquilo que, em sua opinião, devia ser conservado desta posição. Essa doutrina da forma se manifesta na filosofia aristotélica, como se sabe, em diversos planos de análise, por exemplo, nos planos lógico, semântico, psicológico, epistemológico e ontológico.

A posição dos estóicos é radicalmente diversa, dado que eles eliminam a distinção entre um mundo corruptível e um mundo eterno, afirmando enfaticamente a existência de um único mundo (cf. $S V F$ I, 97), a saber, o mundo sensível (cf. SVF II, 328). Além disso, eles também eliminam a diferença, central para Aristóteles, entre matéria e forma, isso porque para eles todos os entes são corpóreos. Dessa nova concepção cosmológica, com efeito, é natural que decorra uma análise do tempo muito diversa daquela que o Estagirita realizou acerca do mesmo. Não apenas isso, mas também toda a teoria da causalidade tem de ser reavaliada. A doutrina de Aristóteles acerca de um Movente Imóvel, pensado como sendo o princípio de todo o movimento, é posta de lado pelos estóicos ao 
eles identificarem essa causa primeira com o próprio movimento (cf. SVF II, 338 e 339). Os estóicos tampouco aceitam a existência de um quinto elemento, o éter, postulado por Aristóteles e essencial para se compreender em sua doutrina a razão dos corpos celestes supralunares, serem incorruptíveis por se constituírem desse elemento que se move circularmente e não retilineamente e não pelos quatro elementos formadores do mundo sublunar, isto é, a terra, a água, o ar e o fogo, que se movem retilineamente (cf. SVF II, 580).

Ante essa nova doutrina cosmológica, é claro que também a célebre definição do tempo concebida por Aristóteles é modificada. Todavia, antes de averiguarmos de que modo essa mudança se processa, cabe perguntar, de um ponto de vista mais geral, o porquê dessa transformação. Acreditamos que um dos principais motivos para isto seja a reavaliação de algumas ideias de Aristóteles por seu amigo e sucessor no Perípato, Teofrasto. Neste pensador, parece residir uma das chaves para se entender o surgimento das filosofias contrastantes que dominaram - antes do advento do que hoje denominamos de neoplatonismo - a filosofia helenística, a saber, o epicurismo e o estoicismo. $\mathrm{Na}$ Metafisica de Teofrasto, encontram-se algumas interessantes passagens que, por assim dizer, começam a pôr em questão gradativamente a doutrina de seu mestre, como, por exemplo, aquelas nas quais ocorre: a) um questionamento a respeito da pretensa imobilidade da causa primeira (parágrafo 16 (Usener)/ $7 b_{9}-8 a_{7}$ (van Raalte)), b) uma reivindicação de uma explicação unitária para o movimento de tudo o que 
existe, desde a causa primeira, passando pelos corpos celestes, até chegar às coisas da natureza (parágrafos. 27 e 28 (Usener) / 9 $b_{24}-10 a_{21}$ (van Raalte)) e, por fim, c) uma crítica à concepção finalista de Aristóteles, fundamentada na observação de inúmeros eventos e fatos da natureza (parágrafos 29 a 32(Usener)/ $10 a_{28}-11 a_{26}$ (van Raalte)).

Após esse breve parêntese, retornemos ao confronto que queremos estabelecer entre Aristóteles e os estóicos, mais particularmente ao confronto entre as diferentes definições do tempo por eles propostas.

O mais importante tratamento dado por Aristóteles ao problema do tempo encontra-se, como se sabe, no quarto livro da Física, especificamente nos capítulos dez a catorze desse livro. Aí é formulada a célebre definição do tempo como "número de um movimento segundo o anterior-posterior" (Phys. IV 11, $219 \mathrm{~b}_{1-2}$ ). A seguir, analisemos, em linhas gerais, cada um dos termos dessa definição confrontando-os com a definição do tempo tal como formulada por Crisipo.

Pode-se constatar, em primeiro lugar, no Estagirita o caráter predicativo por ele adjudicado ao tempo, pois o tempo é dito ser um número do movimento. Ou seja: o tempo é um predicado do movimento, mais precisamente, o seu número. Ao compararmos esta definição com a definição estóica, quer com a de Zenão (cf. $S V F$ I, 93), quer com a de Crisipo (cf. $S V F$ II, 510) nota-se uma diferença fundamental: o tempo nessas teorias não é mais dito ser um número (arithmós) do movimento, como em Aristóteles, mas sim um intervalo (diástẹma) do mesmo. O caráter predicativo do 
tempo permanece inalterado, não, porém, o sentido por ele expresso. Mas alguém poderia legitimamente se perguntar: afinal de contas qual seria a grande diferença em se dizer que o tempo é número ou intervalo do movimento? Implícitos, contudo, a essa aparente pequena diferença conceitual encontram-se duas concepçóes cosmológicas completamente diversas. Embora tanto Aristóteles quanto os estóicos neguem a presença do vazio no cosmo (os estóicos o aceitam, entretanto, como envoltório do cosmo, o que Aristóteles evidentemente também nega) - o primeiro para contrapor-se a Demócrito, os segundos para contraporem-se aos epicuristas -, afirmando assim o seu caráter contínuo, esta continuidade do cosmo, para Aristóteles, é apenas algo passivo, já, para os estóicos, ela apresenta um caráter ativo, pois essa continuidade cósmica é assegurada, segundo eles, pelo pneuma que em sua doutrina tudo unifica e coere. Se em Aristóteles o éter é precisamente um elemento diferente dos outros quatro por mover-se circularmente, o pneuma dos estóicos, ao contrário, imiscui-se com os quatro elementos penetrando-os e formando com eles uma mistura total que se contrapóe claramente à diferença radical que há de acordo com os epicuristas entre os átomos e o vazio. De modo que se para os estóicos as coisas são constituídas pelas diferentes proporçóes de mistura do pneuma com os elementos nelas encontradas, para os epicuristas as coisas são originadas pelas diferentes disposições e encontros dos átomos no vazio. Resta explicar ainda porque dissemos que o contínuo para o Estagirita possui um caráter pas- 
sivo. A definição positiva que Aristóteles nos oferece do contínuo é a de que "todo contínuo é divisível em partes sempre divisíveis" (Phys. VI 1, $231 \mathrm{~b}_{16}$ ). Atentese para o fato de que a ênfase desta definição está na divisibilidade potencial do contínuo e não no produto efetivo da sua divisão, mesmo porque um contínuo continuará sendo um contínuo independente do número de vezes em que ele tiver sido efetivamente dividido, pois, por definição, ele jamais poderá ser reduzido a elementos discretos que o constituiriam. $\mathrm{O}$ ato de dividir depende, portanto, de um intelecto capaz de executar esta operação, tal qual o ato de numerar um movimento também depende necessariamente de um intelecto capaz de numerar. É o intelecto humano, por conseguinte, que desempenha um papel ativo e não as estruturas contínuas presentes na natureza - grandeza, movimento e tempo -, que servem apenas como suporte material para as operaçôes do intelecto. A desconsideração do conceito de número por parte dos estóicos parece apontar para a desconsideração que eles tinham pela diversidade, central para Aristóteles, entre o intelecto e a matéria, ou, se quisermos dizê-lo em termos quantitativos, entre o discreto e o contínuo.

Um outro ponto em que se percebe uma aparente similaridade, camuflando, na verdade, uma diversidade radical é o que diz respeito ao tipo de movimento numerado pelo tempo. Para Aristóteles, a fim de evitar uma relativização indevida do tempo, este só pode ser número do movimento circular, uniforme e constante das esferas supralunares. Para Crisipo (cf. SVF II, 509) também o tempo deve ser intervalo do movimento 
do mundo. Mas, já vimos que a concepção de mundo professada por Aristóteles e pelos estóicos é totalmente distinta. Assim, para o Estagirita o movimento dos céus é eterno, para Crisipo, contudo, ele tem a duração de um ciclo cósmico. Essa diferença também se evidencia ao se comparar a frase de Crisipo que afirma todas as coisas se moverem e existirem no tempo (cf. SVF II, 509) ou uma afirmação análoga de Zenão (cf. SVF I, 93) com a asserção de Aristóteles, no tratado do tempo, de que apenas os entes sujeitos à geração e à corrupção se encontram no tempo, ou melhor, são envolvidos pelo mesmo, não os entes eternos (cf. Phys. IV 12, $\left.221 \mathrm{~b}_{28-30}\right)$.

A análise comparativa do tratado do tempo de Aristóteles e do testemunho que nos resta da posição de Crisipo acerca deste tema (cf. SVF II, 509) é muito proveitosa e demanda, na verdade, um estudo muito mais acurado do que o aqui exposto. Uma outra aparente coincidência entre os dois autores, mas que se mostra, contudo, enganosa é a que se expressa quando Crisipo afirma que o tempo pode ser analisado de dois modos: como totalidade e como parte. Isto porque, o próprio Aristóteles, no início do tratado do tempo adverte o leitor para o fato de que o tempo pode ser considerado de dois modos, a saber, como "o tempo infinito" e "como o tempo que a cada vez podemos apreender novamente" (Phys. $218 \mathrm{a}_{1-2}$ ). A consideração do caráter infinito do tempo, entretanto, só pode ser objeto de intelecção e não de sensação e até mesmo um intervalo de tempo qualquer só poderá, de fato, ser analisado, para Aristóteles, ao ser delimitado por dois 
agoras diversos entre si ao serem numerados segundo o critério de anterioridade e posterioridade. Toda essa atividade exclusiva do intelecto, única instância no homem capaz de conhecer o universal mediante um processo de subtração realizado a partir da exclusão de alguns dos dados obtidos pelos sentidos é desconhecida para os estóicos, dado que, para eles, só existe a sensação (ao menos um tipo de sensação) como fonte verdadeira do conhecimento acerca do que existe efetivamente. Além disso, segundo eles, só existem os entes corpóreos e materiais, embora eles também aceitem, como se sabe, a existência apenas linguística de certos conceitos, como o próprio tempo que é para eles apenas um lektón, ou seja, um dizível.

Retornemos, pois, à definição aristotélica a fim de nos perguntarmos então por um termo que não se encontra explícito nela, mas que é a chave para o correto entendimento da concepção aristotélica do tempo, a saber, o agora, pois nas palavras do próprio Aristóteles "é impossível que se pense ou que exista um tempo sem o agora" (Phys. VIII 1, $251 \mathrm{~b}_{19-20}$ ). Em sua famosa definição do tempo agora se encontra "disfarçado" no termo anterior-posterior, pois é precisamente pela numeração de dois agoras, diversos entre si pela sua ordem sucessiva, que podemos delimitar um intervalo de tempo. Ora, Aristóteles não se cansa de observar que o agora, tal como ele o entende na Física, não pode ser extenso, mas sim um limite inextenso que tem a dupla função de unir e separar dois intervalos de tempo. Postular um agora extenso significaria, como nos esclarece o Estagirita, incorrer em uma contradi- 
ção, pois significaria afirmar algo do passado no futuro e algo do futuro no passado, logo o agora tem de ser algo indivisível (cf. Phys. VI 3, $234 \mathrm{a}_{11-14}$ ). A definição estóica, entretanto, viola justamente essa ideia, central para Aristóteles, da existência de um agora indivisível. Com efeito, eles substituem a discussão sobre o agora pela discussão acerca do presente. E este não pode ser algo indivisível, dado que na natureza, segundo eles, só há corpos. Enquanto indivisível o presente é apenas algo dizível (lektón), como diria Crisipo, mas não algo que exista de fato. O presente que efetivamente existe parece então ser somente aquele que é apreendido por meio dos sentidos e que é necessariamente algo extenso. Seria por esta razão que Crisipo teria definido o tempo como um intervalo do movimento do mundo? Neste caso, o tempo presente só poderia existir ao ser delimitado pelas ações humanas, dado que para os estóicos só o que é corpóreo pode determinar o incorpóreo.

Vimos nesta breve comparação a grande diferença que há entre a concepção físico-cosmo-teológica de Aristóteles e o seu correlato na doutrina estóica ao focalizarmos as distintas concepções que ambas essas correntes do pensamento antigo possuíam acerca do tempo. Vejamos agora de que modo essas diferentes visões do mundo influenciaram a elaboração de diferentes noções de causalidade defendidas por nossos protagonistas.

O princípio primeiro para Aristóteles, como se sabe, é o Movente Imóvel. Já vimos como esse princípio começa a ser questionado por seu sucessor no Perípato, Teofrasto. Os estóicos assinalam então, na 
verdade, uma etapa ulterior dessa rejeição, pois para eles o Movente Imóvel só pode atuar como causa eficiente para dizê-lo em termos aristotélicos. Melhor ainda: para eles não é possível estabelecer uma diferença real entre causa eficiente e causa final, razão pela qual eles identificam o destino com a providência. Já aludimos também ao fato de que a compreensão dos eventos naturais para Aristóteles baseia-se na compreensão da experiência técnico/artística, o que é esperado, pois um dos princípios metodológicos fundamentais da filosofia aristotélica é o de que devemos partir sempre do que é mais conhecido para nós em direção ao que é mais conhecido em si e a experiência artística nos é obviamente mais conhecida do que o mundo físico. Por conseguinte, é precisamente pela observação da relação entre o artesão ou o técnico e a sua obra que a teoria das quatro causas ou, mais precisamente, dos quatro sentidos de causa de Aristóteles é concebida. Essas causas seriam: a causa eficiente (o artista), a causa formal (a ideia da obra na mente do artista), a causa material (a matéria com a qual o artista trabalha) e a causa final (o objetivo pelo qual o artista executa a obra).

Ora, o paradigma estóico para pensar a natureza não é esse modelo artístico, mas sim um modelo, por assim dizer, estritamente determinista, no qual os eventos anteriores implicam os posteriores. Para os estóicos nada que não seja corpóreo pode servir como causa (cf. SVF I, 89), logo eles deduzem que a causa primeira, ou seja, Deus deve necessariamente ser algo corpóreo. Em outras palavras: Deus é identificado ao próprio universo e ao céu (cf. SVF I, 163). Vê-se aqui, 
com clareza, a que distância nos encontramos do modelo aristotélico que concebia Deus como ato puro, pensamento de seu próprio pensamento e, portanto, radicalmente separado do mundo físico. Cabe mencionar um segundo aspecto essencial (o primeiro é a sucessividade determinista) da causalidade estóica, a saber, a contiguidade, dado que para eles um corpo deve necessariamente atuar diretamente sobre um outro corpo com o qual está em contato (cf. SVF II, 346) ou, ao menos, com o pneuma que é o meio corporal que unifica todos os corpos. Aqui se percebe claramente um desenvolvimento que leva às últimas consequências a tese central da física aristotélica que nega a existência do vazio para poder pensar a natureza.

A melhor comparação entre essas duas diferentes concepções de causalidade, a estóica e a aristotélica, nos é transmitida por Alexandre de Afrodísia nos capítulos 22 a 25 de sua obra Sobre o Destino. Para Crisipo, por exemplo, segundo nos relata Alexandre, o mundo era uma trama única de eventos causais, da qual nada poderia escapar, ou seja, todos os fatos do universo deveriam guardar entre si uma relação de implicação condicionante, nenhum fato poderia escapar a essa cadeia causal inquebrantável, pois caso isto ocorresse, então o mundo se fragmentaria, não podendo mais ser governado por "uma só ordem e economia" (cf. SVF II, 945). Conquanto os estóicos diferenciem a causa produtiva (parektikón) - no duplo sentido de ter produzido ou de poder produzir algo - em diversas submodalidades, a saber, as causas preparatórias ou incoativas (prokatarktiká), as causas autodeterminantes (autotele- 
is) ou coessenciais (synektiká), as causas coadjuvantes (synergá) e as condições necessárias (tà ouk áneu) (cf. SVF II, 344-346) (causa preparatória ou incoativa é aquela que oferece as condições para que algo ocorra, causa autodeterminante ou essencial é aquela que por si mesma produz um efeito, causa coadjuvante é aquela que indica a coordenação e a cooperação com uma outra causa, só assim sendo capaz de produzir um efeito e, por fim, as condições necessárias que não são propriamente causas, por não serem corpóreas, mas sem as quais não se poderia pensar a causalidade, tal como o tempo (cf. SVF II, 346, 351 e 353)), eles, na verdade, postulam uma única causa, o agente, como nos diz Sêneca (cf. SVF II, 346a) e este agente outro não é do que o próprio Destino, a Natureza ou Deus, termos que para Crisipo, como para outros estóicos, se identificam (cf. SVF II, 945) 28 .

Ora, Alexandre, diante dessa cadeia causal inexorável, afirma que, contrariamente ao que os estóicos supõem, nem tudo que existe agora produzirá necessariamente alguma outra coisa. Em outras palavras, nem todo antecedente é necessariamente causa de um consequente, como ele nos explica por meio de exemplos triviais e cotidianos. Em suma: o que existe agora não causará necessariamente um efeito futuro. Segundo Alexandre, a relação causal, mais especificamente a relação da causalidade eficiente, não pode ser obtida

28 Sobre a doutrina estóica da causalidade ver o excelente livro de J.-J. Duhot, La conception stoïcienne de la causalité. 
do antecedente para o consequente, mas apenas deste para aquele. Ou seja: a explicação causal deve ser dada a partir do dado presente, que é, na verdade, o consequente (cf. Sobre o Destino, 24). Procedendo desta forma, segundo Alexandre, nenhum evento será sem causa (o que os estóicos aprovariam), mas nenhum evento será determinado pelo destino (o que os estóicos rejeitariam), isso porque, embora todo fenômeno tenha um antecedente, nem sempre esse antecedente é a sua causa própria, às vezes o fenômeno pode ter sido produzido apenas por uma causa concomitante, ou seja, por uma convergência casual de duas cadeias causais próprias que produziram um evento novo e inesperado. Eis então a razão de Aristóteles afirmar que no mundo sublunar os eventos não ocorrem necessariamente, mas apenas no mais das vezes. Alexandre explica igualmente que nem toda sucessão pode ser pensada em termos causais, dado que seria totalmente absurdo atribuir a causa do caminhar ao pôr-se de pé ou a causa do dia à noite, antes os eventos anteriores e posteriores devem ser pensados muitas vezes como tendo uma causa comum, como nos exemplos, por ele enumerados, a saber, a causa tanto do caminhar quanto do pôr-se de pé é o resultado do ato deliberativo de um indivíduo, e a causa do dia e da noite, como de outros eventos cíclicos da natureza, reside na revolução dos corpos celestes. Por fim, Alexandre rejeita também a doutrina de Crisipo sobre a infinitude inicial e final do universo (cf. SVF II, 945), porque, segundo o Estagirita, é impossível pensar em uma cadeia causal infinita, pois o pensamento necessita sempre alicerçar-se 
em um princípio estável, função esta que na filosofia aristotélica é desempenhada pelo Movente Imóvel (cf. Metaph. $994 \mathrm{a}_{16} \mathrm{e} \mathrm{b}_{20}$ ).

Em síntese, a diferença que Alexandre estabelece entre a filosofia de Aristóteles e a dos estóicos no tocante à causalidade, consiste em que se para o Estagirita ela deve ser pensada a posteriori em função da contingência, para os estóicos ela pode ser pensada a priori, pois há o destino. Essa diferente visão do mundo físico, portanto, influirá decisivamente na elaboração da lógica aristotélica e estóica (particularmente elaborada por Crisipo). Vejamos de que modo isso ocorre.

Em primeiro lugar, é preciso assinalar uma diferença básica entre o silogismo aristotélico e o crisipeano. O primeiro é definido como sendo um tipo de discurso no qual, estabelecidas certas premissas, segue-se necessariamente uma conclusão (cf. An. pr. I, $24 \mathrm{~b}_{19-20}$ ). Esse caráter necessário da conclusão, justamente com o conhecimento do por que, isto é, da causa de um fenômeno qualquer são os atributos constitutivos da noção de ciência (epistémê) tal como entendida por Aristóteles. Ora, sabe-se hoje que o método silogístico é pensado a partir da geometria de Eudoxo, razão pela qual o Estagirita jamais poderia tê-lo utilizado no que concerne à ciência da natureza, pelo fato de que ele mesmo criticava enfaticamente o projeto platônico desenvolvido no Timeu - e que ele não interpretava como sendo um mero relato mítico - de reduzir a natureza à geometria. Logo, não é de causar espanto o fato de que a maior parte das obras de Aristóteles não seja escrita more geométrico, isto é, segundo uma estru- 
tura estritamente silogística, dado que a quase totalidade de seus escritos referem-se à natureza do mundo sublunar que, na sua doutrina, como se sabe, é totalmente avessa a um necessitarismo rigoroso. $\mathrm{O}$ caráter dedutivo do silogismo permite que ele seja aplicado somente aos eventos necessários da natureza supralunar (a predição de um eclipse, por exemplo). Este tipo de silogismo, contudo, não pode ser aplicado aos fenômenos da natureza sublunar, dado eles não serem necessários, mas contingentes, de onde há presença do acaso e do espontâneo nesse âmbito. O silogismo para ser aplicado à física sublunar tem de ser pensado a partir do evento posterior (cf. An. post. $95 \mathrm{a}_{28}$ ). No domínio da natureza, portanto, deve-se partir do efeito e retroagir em direção à causa, na medida em que nem todo evento antecedente na natureza produzirá necessariamente um efeito, mas tudo na natureza possui uma causa, seja ela própria ou concomitante (ou seja: produzida por uma concatenação casual ou fortuita de duas séries causais). Outra característica central do silogismo aristotélico é que ele nunca se utiliza de termos particulares, mas sempre universais, por isso as constantes lógicas de seu silogismo são os quatro tipos de predicação: referentes a todos (A), a nenhum (E), a alguns (I) e não a todos $(\mathrm{O})$.

Ao compararmos esse tipo de silogismo com o silogismo elaborado por Crisipo percebemos a enorme distância que os separa, distância esta oriunda de duas concepçôes físico-cosmo-teológicas totalmente diversas. A inclusão da lógica, por parte dos estóicos, como uma das três partes da filosofia, já inovava em relação a 
Aristóteles que parecia considerar essa disciplina apenas como propedêutica, ao menos foi assim que Andrônico a entendeu e a posteridade o seguiu quase que cegamente. Além disso, outra diferença fundamental consiste no fato de que para Crisipo o silogismo se estruturava somente com dois termos e não com três termos (como em Aristóteles) e a mediação não era estabelecida a partir de um termo com função atributiva, mas sim em função do posicionamento que os dois termos tinham na conexão da proposição. Por exemplo: "se é dia, há luz - mas é dia - logo há luz". A segunda proposição retoma a primeira parte da proposição hipotética inicial, já a conclusão retoma a parte final desta primeira proposição (cf. SVF II, 242). Crisipo propunha mais quatro variantes desse tipo de silogismo, todos considerados por ele como conclusivos, mas não como verdadeiros, dado que para que um silogismo fosse considerado como verdadeiro, para Crisipo, os seus termos precisariam existir de fato, como no caso do exemplo acima, caso se verificasse a sua realidade (cf. SVF II, 239).

A lógica estóica, portanto, a diferença da de Aristóteles, fundamentava-se nos eventos concretos e nos fatos particulares, que eram concebidos como corpóreos e materiais. Disso resulta outra diferença entre as duas lógicas, a saber: a silogística aristotélica baseava-se em um princípio demonstrativo intelectual, enquanto que os estóicos concebiam a demonstração como um procedimento empírico, pois fundamentado nos dados sensoriais. O silogismo demonstrativo, para Crisipo, alicerçava-se mais precisamente no sinal (semê̂on). 
É importante observar, que nem todo silogismo hipotético, nem mesmo aquele que parte de uma premissa verdadeira e termina com outra premissa verdadeira (como no exemplo acima mencionado da luz e do dia) opera por meio de um sinal, isto é, o fato de haver luz não é algo que revele a essência do dia, mas é algo que se percebe por si mesmo, logo esse é um silogismo verdadeiro, mas não demonstrativo. $\mathrm{O}$ sinal, portanto, deve revelar o consequente, como no seguinte exemplo: "se uma mulher produz leite, isto quer dizer que ela deu à luz". Uma característica essencial do sinal, para Crisipo, é que ele existe no presente e indica necessariamente algo presente e não algo passado ou futuro (cf. SVF II, 221).

Constatadas as diferenças entre Aristóteles e os estóicos no que se refere ao modo de compreender o mundo físico em geral e mais particularmente ao modo de compreender o tempo, a causalidade e o silogismo, é óbvio que só poderíamos encontrar uma diversidade similar no que tange as suas concepçōes sobre a lógica modal. Para Aristóteles as modalidades estão em estrita relação com os tipos de essência, de modo que necessários, em sentido estrito, são apenas os entes eternos e imperecíveis, bem como possíveis e contingentes apenas os entes temporais e sujeitos à geração e à corrupção. Pode-se dizer desses entes contingentes que eles procuram imitar por meio de seu ciclo de geração e corrupção o movimento circular e constante dos corpos celestes e a relação que eles mantêm com os céus seja uma relação de emulação (cf. De gen. et corrup. $336 \mathrm{~b}_{34}-337$ a, e Metaph. $\Theta 8,1050 \mathrm{~b}_{28-29}$ ). 
Os corpos celestes são eternos em sentido próprio por possuírem uma identidade numérica, enquanto os organismos do mundo físico sublunar são eternos apenas em sentido impróprio pelo fato de, por sua sucessão ininterrupta, produzirem uma pseudo-eternidade, ou seja, uma eternidade específica e não numérica (cf. De gen. et corrup. $338 \mathrm{~b}_{11-17}$; De an. $415 \mathrm{~b}_{3-7}$ e De gen . an. $\left.731 \mathrm{~b}_{22}-732 \mathrm{a}_{1}\right)$. $\mathrm{O}$ caráter necessário desses entes não apresenta, por conseguinte, o mesmo tipo de necessidade presente nos entes eternos, considerados em sentido estrito. Essa necessidade dos entes propriamente eternos é absoluta, enquanto que a necessidade daqueles entes perecíveis é denominada hipotética (cf. De gen. et corrup. $337 \mathrm{~b}_{20-29}$ ), pois depende de certas condiçōes.

É no interior desse quadro mais geral acerca da modalidade que devemos inserir a famosa problemática do futuro contingente como desenvolvida por Aristóteles no célebre capítulo nove do De interpretatione. Todo o problema desse capítulo gira em torno da questão de saber se é possível ou não emitir um juízo verdadeiro ou falso sobre uma hipotética batalha naval que deveria ocorrer no futuro. Ora, se Aristóteles aceita o caráter necessário do que existe no presente, isso não quer dizer que não haja diferença entre a necessidade, digamos, do movimento do Sol e do movimento de um homem que passeia de sua casa até a ágora. Ambos os eventos enquanto estão ocorrendo são necessários, mas a necessidade do segundo não é absoluta, mas apenas hipotética. Ou seja: é necessário que o Sol se mova circularmente ao redor da Terra e isso ocorre independentemente de qualquer determinação tempo- 
ral, pois o Sol é um organismo composto de matéria incorruptível, o éter, que se move circularmente e cujo movimento desconhece início ou fim, dado que, para Aristóteles, o cosmo é eterno. Já no caso do indivíduo que saiu de casa em direção a ágora, isso poderia não ter ocorrido, ou ele poderia ter saído de casa com a intenção de ir a ágora e por um motivo qualquer não ter caminhado mais do que dois ou três passos e se detido. Enfim, não há nenhuma necessidade que o que existe agora, no caso de ser algo sujeito à geração e à corrupção, tenha existido no passado ou que venha a existir no futuro. Logo, segundo Aristóteles, não é possível emitir antecipadamente um juízo verdadeiro ou falso sobre um acontecimento contingente futuro. Admitir essa possibilidade seria, para ele, violar a própria contingência dos fenômenos naturais que ocorrem apenas no mais das vezes, mas não sempre.

Ao nos situarmos na perspectiva estóica, o entendimento da lógica modal é radicalmente diverso. É preciso mencionar, ainda que somente en passant, o famoso "argumento do dominador", que está por trás da solução aristotélica, exposta no parágrafo acima, acerca dos modos lógicos, a saber, o necessário, o possível, o contingente e o impossível. Ora, o problema lógico que Diodoro legou a seus pósteros era o de conciliar as seguintes três asserções: a) toda proposição relativa ao passado é necessária; b) o impossível não segue logicamente do possível e c) é possível o que não é atualmente verdadeiro e não o será. Diante desse desafio, os megáricos e os estóicos tentaram dar diferentes respostas. Assim, a resposta do megárico Diadoro 
Crono aceita as duas primeiras sentenças e rejeita a última, a resposta de Cleanto aceita as duas últimas e refuta a primeira e, por fim, a solução de Crisipo é a de aceitar a primeira e a última e de refutar a segunda. Percebe-se nessas soluções um caminho que parte do necessitarismo absoluto de Diodoro, que nega a própria noção de possibilidade, para uma refutação do caráter necessitarista do passado em Cleanto e que culmina em uma refutação, por parte de Crisipo, não do caráter irreversível do passado, mas sim da negação da noção de possível em Diodoro. Para isso, Crisipo tinha de afirmar a validade da passagem do que é possível para o que não é possível, em outras palavras, o que ele queria era salvar a noção mesma de possível. Mas a noção de possível em Crisipo e em Aristóteles são obviamente diversas. Em Aristóteles o possível indica, de modo geral, que um evento pode ou não ocorrer no futuro, enquanto em Crisipo o possível não assinala uma possibilidade real de que algo possa efetivamente ocorrer no futuro, diversamente de como havia sido estabelecido pela Providência, mas apenas que esta coisa pode ser pensada como possível, mesmo que jamais ocorra.

A consequência prática dessa postura necessitarista, mais ou menos mitigada, foi o enorme interesse que os estóicos tiveram pelas práticas divinatórias. Estas seriam como que a comprovação experimental de que há um nexo causal universal que determina direta ou indiretamente todas as coisas (cf. SVF II, 939). Nunca é demais explicar que os estóicos não acreditavam pura e simplesmente que a observação do vôo dos pássaros, 
por exemplo, seria a causa que determinaria um acontecimento futuro, digamos o sucesso de uma colheita, mas sim que a providência concatenou eventos aparentemente sem nenhuma relação entre si, de modo que entre o vôo dos pássaros e o acontecimento futuro que se quer conhecer haja uma mesma cadeia causal, o que permitirá, por meio de uma atenta observação do tipo de vôo realizado pelos pássaros, predizer se haverá ou não uma boa colheita. A preocupação principal de Crisipo, acerca desse problema das práticas divinatórias, era a de mitigar um necessitarismo de cunho astrológico (de origem caldáica), de forma a não abdicar da responsabilidade moral do homem. Assim, como Cícero nos relata na sua obra De fato, Crisipo propunha substituir uma asserção condicional característica da prática astrológica, como, por exemplo, "se alguém tiver nascido ao início da canícula, ele não morrerá no mar" por uma conjuntiva negativa do tipo: "não ocorre que alguém nasça no início da canícula e que morra no mar". O que significa essa transformação de uma condicional em uma conjuntiva? Para Cícero, apenas um jogo de palavras (De fato, VII, 14 e VIII, 15; cf. os comentários de Hamelin). Entretanto, tudo parece indicar que o problema para o qual Crisipo queria apontar era para o fato de que as prediçôes parecem não satisfazer o critério de verdade das asserçôes condicionais, isso porque nestas o antecedente não é logicamente incompatível com o contraditório do consequente, mas essa incompatibilidade é apenas empírica. No caso das conjuntivas, o antecedente não é mais passado e, portanto, não é necessário, ou seja, 
não ocorre uma implicação, em sentido estrito, do antecedente para o consequente. A sentença condicional dos astrólogos exprime que é necessário que se A ocorrer, B não ocorrerá, enquanto a conjuntiva negativa de Crisipo exprime apenas que não é possível que ocorra A e que ocorra B. A intenção de Crisipo, em suma, é, como já dissemos, a de salvar o possível, sem, contudo, abolir o Destino.

Vimos até aqui como todas as diferenças existentes entre Aristóteles e os estóicos, quais sejam, as diferenças entre as suas concepções de tempo, de causalidade e de lógica convergem para a noção de destino, ou poderíamos também dizer, considerando as coisas a partir de outra perspectiva, como todos esses problemas derivam da discussão acerca do destino. Concluamos, pois, este breve texto discutindo em linhas gerais a noção de destino em Aristóteles e nos estóicos.

Em Aristóteles, a referência ao destino é raríssima. Do nosso conhecimento há apenas duas passagens significativas para o nosso estudo, uma referindo-se ao conceito homérico de destino, moîra, e a outra se referindo ao conceito criado pelos filósofos para designar o destino, heimarméne. $\mathrm{O}$ passo que se refere ao termo já utilizado por Homero para designar o destino aparece no primeiro livro da Ética a Nicômacos, quando Aristóteles se pergunta se a felicidade é algo apreendido (posição dos sofistas) ou adquirido por exercícios (posição de Antístenes), ou ainda, se é algo adquirido por um quinhão divino (katá tina theían moîran) (posição de Platão, cf. Menon, 99 e) ou pela fortuna (dià týkhen) (posição tradicional) (E.N. I, 10, $1099 \mathrm{~b}_{9-11}$ ). 
O que está em debate nesse capítulo, portanto, é saber se a felicidade possui causas intrínsecas ou extrínsecas ao homem e a resposta de Aristóteles é a de que o homem é ele mesmo o princípio de sua felicidade. A segunda e para nós mais importante passagem sobre a problemática do destino ocorre na Física. O Estagirita se pergunta no passo em questão se não existiriam gerações violentas (genéseis bíaoi) e não impostas pelo destino (oukh heimarménai), as quais seriam contrárias àquelas que ocorrem conforme a natureza (katà phýsin) (cf. Phys. V 6, $230 \mathrm{a}_{31-32}$ ). A contraposição é clara: existem acontecimentos naturais e violentos. Os primeiros têm a sua causa em si mesmo, os segundos não. Mais importante para nós: Aristóteles associa as gerações violentas à não imposição pelo destino dessas gerações e as contrapõem às gerações naturais, logo, os acontecimentos naturais são aqueles que são impostos pelo destino. Em suma: o destino é um outro nome para a ordem natural das coisas. Mas, como já vimos anteriormente, os processos naturais para Aristóteles não ocorrem necessariamente, mas apenas no mais das vezes e isso é assim porque há processos naturais que ocorrem devido ao acaso (autómaton) ou, nos entes capazes de deliberação, devido à fortuna (týkhe $)$. É precisamente por esta razão que, na perspectiva aristotélica, deve-se proceder na busca das causas dos fenômenos naturais do consequente para o antecedente, pois, embora todo evento tenha uma causa, essa causa pode não ser a sua própria, mas sim uma causa concorrente ou concomitante (symbebękós) e essa se caracteriza por permanecer sempre indeterminada (sobre toda essa problemática cf. Phys. II, 4-6). 
Ao passarmos à concepção estóica do Destino, vemos claramente a mesma associação do Destino com a Natureza (cf. SVF I, 176 (Zenão) e SVF II, 913 (Crisipo)). O problema, como já vimos, é que a concepção da natureza para os estóicos é totalmente diversa da de Aristóteles. Ao abolirem a distinção aristotélica entre um mundo necessário e um mundo sujeito às contingências, os estóicos podiam facilmente postular uma única cadeia causal que determinaria todos os eventos existentes, de modo que até mesmo as decisões e escolhas dos homens já estariam previstas pelo Destino-Providência (cf. SVF II, 998). Cabe observar aqui que, embora Crisipo não elimine pura e simplesmente a deliberação humana, mas a tente incluir num Destino-Providência que já previra de antemão essa intervenção humana (cf. SVF II, 1000), os opositores dos estóicos foram movidos, em seus libelos contra esses pensadores, principalmente pelas implicações políticas da doutrina estóica (é o caso, por exemplo, de duas das mais importantes obras remanescentes desse debate, a saber, o De fato de Cícero e o Sobre o Destino de Alexandre de Afrodísia). Temia-se primordialmente que essa concepção estóica do destino pudesse levar os homens à indiferença moral e política e, mais grave ainda, à própria inutilidade das leis e da justiça, pois como imputar responsabilidade moral a um ato qualquer de um indivíduo, caso ele mesmo não seja, em última instância, o responsável por esse ato?

Ao final deste texto, é lícito mencionar a possibilidade de uma futura expansão destas ideias em duas novas etapas. A primeira delas ocupar-se-ia com as 
críticas e as reflexões sobre o destino e a providência por parte da tradição platônica e neoplatônica. Aqui caberia investigar o tratado Sobre o Destino do PseudoPlutarco, bem como as discussões de Plotino (Enéadas III, 1-3) e de Proclo (os três pequenos tratados, conservados apenas na sua versão latina, e conhecidos como Tria Opuscula) acerca desse tema. A etapa ulterior ocupar-se-ia, então, da recepção cristã desse debate, quer na sua vertente grega, quer na sua vertente latina. Da cristandade grega, caberia citar especialmente Orígenes, Gregório de Nissa e João Crisóstomo, pois todos eles redigiram tratados sobre o destino. Da latina pensamos especialmente em Agostinho (De civ. dei V, 1-9), Tertuliano e Boécio (De cons. phil. IV, prosa 6) que também discutiram sobre o Destino e a Providência. De modo geral, pode-se dizer que toda essa reflexão sobre o Destino e a Providência desenvolvida pelos neoplatônicos e pelos cristãos visava diferenciar o Destino da Providência, identificada pelos estóicos, a partir de uma nova reelaboração de uma cisão constitutiva entre dois planos da realidade: o do absoluto e o do relativo, ou se quisermos dizê-lo com os termos cristãos, o de Deus e o das criaturas. A Providência diz respeito ao $\mathrm{Um}$, como diriam os neoplatônicos, ou a Deus, como diriam os cristãos, enquanto o destino se refere ao nosso mundo. Desta forma, tenta-se conservar a Providência divina e salvaguardar o livre arbítrio dos homens, mas a análise desse problema já seria assunto para um outro texto. 
(Página deixada propositadamente em branco) 


\section{BIBLIOGRAFIA RESUMIDA}

\section{EDIÇÃO COMPLETA}

Aristotelis, Opera ex recensione I. Bekker, Academia Regia Borussica, Berlim, 1831-1870; Editio altera quam curavit O.Gigon, 4 vols., W. de Gruyter, Berlim, 1960-1961.

\section{SELEÇÃO DE FRAGMENTOS}

H. von Arnim, Stoicorum Veterum Fragmenta, Lipsia 19031905; ed. anast. Stuttgardie, 1964 (4 vols.)

M. Isnardi Parente, Gli Soici. Opere e Testimonianze, 2 vols., UTET, Torino, 1989.

\section{EDIÇÕES DE OBRAS AVULSAS DE ARISTÓTELES}

Aristotelis, Categoriae et Liber de Interpretatione, ed. L.MinioPaluello, Oxford University Press, Oxford, 1986 (1946¹). 
Aristotle's Physics, A revised text with introduction and commentary by W.D.Ross, Clarendon Press, Oxford, 1955 (1936'1).

Aristotle, On Coming-to-be and Passing-away (De generatione et corruptione), A revised text with introduction and commentary by H.H.Joachin, Georg Olms, Hildesheim/ New York, $1970\left(1922^{1}\right)$.

\section{LITERATURA SECUNDÁRIA SOBRE OS ESTÓICOS}

Duhot, Jean-Joël. La conception stoicïenne de la causalité, Vrin, Paris, 1989.

Goldschmidt, Victor. Le Système Stö̈cien et l'Idée de Temps, Vrin, Paris, 1977.

Mates, Benson. Stoic Logic, University of California Press, Berkeley/Los Angeles, 1953.

Pohlenz, Max. La Stoa, 2 vols., La Nuova Italia, Firenze, 1978.

Rist, J.M. Stoic Philosophy, Cambridge University Press, Cambridge/New York/Melbourne, 1969.

Sambursky, S. Physics of the Stoics, Princeton University Press, Princeton/New Jersey, 1987 (1959'1).

\section{LITERATURA SECUNDÁRIA SOBRE ARISTÓTELES}

Aubenque, Pierre. La prudence chez Aristote, Vrin, Paris, 1963.

Donini, Pier Luigi. Ethos. Aristotele e il determinismo, Edizioni dell'Orso, Torino, 1989. 
Lukasiewicz, J. Über den Satz von Widerspruchs bei Aristoteles, Olms, Hildesheim, 1993.

Solmsen, F. Aristotle's System of the Physical World. A Comparison with his Predecessors, Cornell University Press, Ithaca, 1960.

Viano, C.A. La lógica di Aristotele, Taylor, Torino, 1955.

Wieland, Wolfgang. Die aristotelische Physik. Untersuchungen über die Grundlagen der Naturwissenschaft und die sachlichen Bedingungen der Prinzipienforschung bei Aristoteles, Vandenhoek und Ruprecht, Göttingen, 1970².

\section{TRATADOS ANTIGOS SOBRE O DESTINO}

Alessandro di Afrodisia. Sul Destino, Introduzione, traduzione e note di A.Magris, Ponte alle Grazie, Firenze, 1995.

Cicerone. Il Fato, Introduzione, traduzione e note di F.Antonini, testo latino a fronte, BUR, Milano, 1994.

Hamelin, Octave. Sur le De fato, publié et annoté par M.Conche, Éditions de Mégare, Limoges, 1978.

\section{OBRAS DE TEOFRASTO}

Teofrasto. Algunas cuestiones de metafisica, Introducción, traducción y notas de M.Candel, Edición bilingüe, Anthropos, Madrid, 1991.

Teofrasto. Sobre las Sensasiones, Edición, introducción, traducción y notas de J.S. Dueso, Anthropos, Madrid, 1989.

Teophrastus. De sensibus, ed. G.M.Stratton, Bonset/Schippers, Amsterdam, $1964\left(1917^{1}\right)$. 
Teophrastus. Metaphysics with introduction, translation and commentary by Marlein van Raalte, Brill, Leiden/New York/Köln, 1993. 


\section{TEMPO E AÇÃO EM ARISTÓTELES}

presente texto tem por objetivo mostrar, em primeiro lugar, a íntima conexão entre o fim (télos) e o princípio (arkhế) na explicação do movimento dos animais, considerado em sentido lato, tanto no plano psico-fisiológico da locomoção quanto no plano ético-político da ação. Em ambos os casos o fim e o princípio, considerados literal ou metaforicamente, coincidem e é precisamente a partir desse lugar de articulação, igualmente entendido literal ou metaforicamente, do princípio e do fim que a locomoção eficaz ou a ação responsável se produzem.

Em segundo lugar, procuraremos mostrar a importância de Aristóteles salvaguardar a diferenciação modal entre passado, presente e futuro no âmbito ético, ao contrário da sua tentativa de superação desses termos, por meio da noção quantitativa de anteriorposterior no célebre tratado que escreveu sobre o tempo no quarto livro da Física (Phys. IV 10 - 14). 
Isso ocorre, pois o assim chamado silogismo prático se fundamenta e estrutura precisamente a partir dessa diferenciação modal do tempo.

Com este intuito, nos utilizaremos basicamente dos seguintes textos de Aristóteles: o importante opúsculo De motu animalium e os capítulos nove, dez e onze do terceiro livro do De anima que tratam especificamente das causas da locomoção e da ação humanas.

A necessidade de analisar esses dois textos conjuntamente advém do fato que os densos e sucintos capítulos do De anima acima referidos muitas vezes não fazem mais do que aludir esquematicamente a alguns importantes tópicos acerca do movimento dos animais que só receberão um pleno desdobramento teórico no âmbito do breve, mas essencial tratado conhecido pelo título latino De motu animalium.

A grande inovação de Aristóteles nos textos que investigamos no âmbito deste texto foi a de cunhar um termo único para dar conta de explicar o processo que leva todos os animais, inclusive o homem, a moverem-se em direção a algo como resposta a um estímulo que eles receberam por meio de sua faculdade discriminante (kritikón), seja uma percepção (aisthesis), uma imagem (phántasma) ou um pensamento (diánoia), e que podem se reportar à inteligência (noûs). Esse termo é órexis (tendência), desconhecido antes de Aristóteles e criado por ele precisamente para explicar a causa comum do movimento dos animais (a tendência, como ele explica, compreende o querer (boúleusis), o impulso (thymós) e o desejo (epithymía); cf. De motu animalium $700 \mathrm{~b}_{22}$ ). Ora, como o Estagirita mostra 
no nono capítulo do terceiro livro do De anima, nenhuma das faculdades por ele anteriormente estudadas nesse texto - a nutritiva (threptikón), a sensitiva (aisthetikón) ou a racional (logistikón) - poderia por si só dar conta de esclarecer a razão pela qual os animais se movem. Tampouco a inteligência ou a tendência, se consideradas isoladamente, o poderiam fazer, pois há homens que atuam à revelia da razão e outros que agem em conformidade com ela, caso respectivamente dos incontinentes e dos continentes. A única solução encontrada por Aristóteles é a de postular ambos esses itens - o intelecto $e$ a tendência - como princípios do movimento tópico dos animais, fazendo, contudo, a ressalva de que a faculdade intelectual aqui em questão é de ordem prática e não teorética, ou seja, é aquela que "raciocina em vista de algo" (ho héneka tòn logizómenos). A tendência, por sua vez, também é por ele caracterizada como "o em vista de" (tò hoù héneka). Em suma: ambas essas instâncias constituem então a faculdade apetitiva (orektikón) que é a responsável pelo movimento local dos animais.

Uma sentença do décimo capítulo do terceiro livro do De anima nos possibilita ingressar mais especificamente no nosso tema. Aristóteles afirma que "para onde a tendência se dirige, isso mesmo é o início do intelecto prático e o último termo $<$ do raciocínio prático> é o início da ação" (De an. III 10, $433 \mathrm{a}_{15-17}$ :

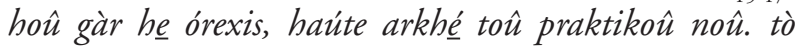
d'éskhaton arkhè tếs práxeós). E, para onde a tendência se dirige? Evidentemente para o bem, seja ele o bem verdadeiro (tò agathón) ou o bem aparente (tò phai- 
nómenon agathón), mas, cabe esclarecer que esse bem não é um bem considerado universalmente, ou seja, não é ao Bem que se aspira, como ocorreria no caso de Platão (cf. EN I onde Aristóteles critica essa doutrina de seu mestre), de acordo com o Estagirita, mas tão somente a um bem prático (tò praktòn agathón), isto é, àquele bem que pode ser de outro modo, logo, que não é necessário.

A seguir, Aristóteles recorre a um modelo, que ele já havia exposto no oitavo livro da Física (cf. Phys. VIII 5, 256 b $_{14-16}$ ), a fim de esclarecer esse ponto. Ele afirma que para entender o movimento é preciso analisar todos os itens que o constituem, a saber, o que move, o que é movido e, por fim, aquilo por meio de quê algo se move. O que move, por sua vez, pode mover de dois modos: pode mover sem ser movido e pode mover sendo movido. No nosso caso, o movente imóvel é precisamente o objeto da tendência (orektón), ou seja, o bem prático (tò praktón agathón), enquanto o movente móvel é a própria faculdade apetitiva (orektikón). O que é movido, por sua vez, é o animal (tò zoón). Por fim, o instrumento com o qual a tendência move deve ser algo corpóreo (somatikón). O que exatamente seria este algo corpóreo não fica claro no âmbito desse texto, entretanto, Aristóteles afirma que isso se encontra "onde princípio e fim são o mesmo, a saber, nas articulações" (De an. III 10, $433 \mathrm{~b}_{22}$ : hópou arkhẹ kai teleutè tò autó, hoîon ho ginglymós). O final desse capítulo conclui com algumas observações extremamente sucintas e por isso mesmo pouco esclarecedoras acerca dessa identidade de fim e princípio nas articulações. 
Uma maior compreensão desses capítulos do De anima pode ser obtida por meio do estudo do opúsculo De motu animalium. O interessante em ambos esses textos é que eles misturam, por assim dizer, diversos planos ou registros de análise, como, por exemplo, a explicação fisiológica e a explanação finalística do movimento dos animais. É interessante observar que, do ponto de vista biográfico, ambos esses textos estão provavelmente dentre os últimos que foram escritos por Aristóteles. O De motu animalium é ainda mais atípico, pois também acrescenta consideraçôes cosmológicas (nos capítulos três e quatro) a todo esse já complexo emaranhado de explicaçōes biológicas e éticas que tentam elucidar a causa comum (koinè aitía) da locomoção dos animais. Nesse sentido, essa obra parece assinalar uma nova etapa no pensamento do Estagirita, uma etapa na qual a célebre proibição de analisar gêneros distintos contida nos Analíticos (cf. An. post. $84 \mathrm{~b}_{14-18}$ e $75 \mathrm{a}_{37 \mathrm{~s}}$ ) parece ter sido abolida a favor de uma investigação mais pluridirecional na qual os dados obtidos em uma ciência podem iluminar os eventos de uma outra (cf. os elucidativos comentários de Nussbaum a esse opúsculo aristotélico).

Os dois primeiros capítulos desse opúsculo mostram detalhadamente de que forma as articulações (kampaî) são essenciais para o movimento dos animais. Para entender plenamente essa explicação fisiológica, contudo, é preciso lembrar-se que, de acordo com o segundo livro da Física, a definição de um ente natural é dada pelo fato de que ele "possui em si mesmo princípio de movimento e repouso" (Phys. II 1, 
$192 \mathrm{~b}_{13-14}$ : en heautô arkhèn ékhei kinéseos kaì stáseos). Ora, o que o primeiro capítulo do De motu animalium explica é que o animal necessita ter em si mesmo um princípio móvel e um imóvel e que por essa razão os animais possuem articulações. Nas articulações os dois princípios se unem em um mesmo lugar, pois em cada movimento articulado que executamos, uma parte fica em repouso, enquanto a outra se move. A condição de mobilidade de uma é a imobilidade da outra. Assim, quando movemos o antebraço o cotovelo permanece imóvel, mas ao movermos todo o braço é o ombro que fica em repouso. Igualmente, quando movemos parte da perna o joelho permanece imóvel, mas ao movermos a perna inteira é a anca a ficar em repouso (uma análise geométrica detalhada do processo do caminhar pode ser lida no capítulo nono do opúsculo De incessu animalium). Por isso, parece-nos, a passagem final do capítulo dez do terceiro livro do De anima afirma que a articulação é formada de duas partes: uma côncava e imóvel e que dá início ao movimento e outra convexa e móvel. Embora distintas conceitualmente essas partes são inseparáveis do ponto de vista da grandeza, pois as suas superfícies coincidem (cf. De an. $433 \mathrm{~b}_{22-25}$ ). Além da necessidade de algo imóvel (eremoûn ti) dentro de si, os animais necessitam também de algo imóvel fora de si, a fim de que possam se mover, seja na terra, na água ou no ar. Isso porque para que os animais se movam é preciso que o meio no qual se encontrem ofereça-lhes resistência (antéreisis), do contrário seria impossível haver movimento. Por essa razão, por exemplo, não é possível que um animal caminhe sobre 
a areia movediça (cf. De motu animalium, 2 e De incessu animalium, 3).

Note-se que as considerações relativas ao movimento do cosmo não são descabidas, pois na filosofia aristotélica o cosmo juntamente com as plantas, os animais e os elementos simples são os únicos entes móveis que efetivamente existem. Não nos esqueçamos que, como o Estagirita repete em inúmeros textos, os corpos celestes também são seres animados, ou seja, seres que agem e vivem (cf. De caelo, $292 \mathrm{a}_{18-21}$; até mesmo Deus, cabe recordar, é pensado por Aristóteles como tendo vida e, portanto, como sendo um vivente, na verdade, como sendo o ser vivo por antonomásia, cuja vida é eterna e nobilíssima, cf. Metaph. 7, $\left.1072 \mathrm{~b}_{28-29}\right)$.

Igualmente, é ao pequeno tratado sobre o movimento dos animais que devemos recorrer para compreender o que é aquele algo corpóreo aludido no $D e$ anima e que causaria o movimento dos animais. $\mathrm{O}$ décimo capítulo dessa breve obra nos elucida que esse algo corpóreo é o pneuma inato (pnêิma sýmphyton) que se localiza, como Aristóteles nos diz alhures, ao redor do coração na região dos pulmões (cf. De motu an. $703 \mathrm{a}_{13 \mathrm{ss}}$ e sobre uma detalhada análise do coração ver De part. an. $\left.665 \mathrm{~b}_{6}-667 \mathrm{~b}_{14}\right)$. É o coração, portanto, que é propriamente a causa motriz do animal, pois é dele que partem os movimentos de expansão e contração, correspondentes às duas funções do movimento, quais sejam, a de puxar e a de empurrar, e que, graças ao pneuma, propagar-se-ão por todo organismo. Por isso, Aristóteles chega até mesmo a considerar 
o coração, em outra obra, como se fosse um ser vivo (isto é: um animal) localizado no interior dos animais em que se encontra (cf. De part. an. 666 b $_{13-16}$ ). O pneuma seria assim, segundo o Estagirita, o meio ideal para a propagação do movimento, pois ele não sofre nenhuma alteração ao se contrair e expandir (cf. De motu an. $703 \mathrm{a}_{19-24}$ ). Resumindo: o coração, sendo a sede da vida é também a sede de todas as sensaçôes e de todos os movimentos (cf. De part. an. $665 \mathrm{a}_{10-11}$ ) e o pneuma inato é o difusor ideal desse movimento para todo o organismo.

A essa altura alguns leitores já podem estar se perguntando: onde afinal se discute a relação entre télos e arkhé no meio desse emaranhado de conceitos? Bem, uma boa resposta seria dizer que essa relação entre princípio e fim já está implicitamente presente em todos esses planos de análise, se observados atentamente. Iniciemos com o mais óbvio, o plano fisiológico. Aqui as articulações desempenham claramente o papel de motores isolados, onde princípio e fim coincidem. Ora, esses motores só podem proceder de modo circular, razão pela qual o próprio Estagirita recorre a essa figura geométrica para explicar o que se passa nas articulaçôes no décimo capítulo do terceiro livro do De anima. Não nos esqueçamos, contudo, que o único movimento perfeito para grande parte dos antigos pensadores gregos era o movimento circular, pois somente nele o início e o fim coincidem (cf. Phys. VII 3, $246 \mathrm{a}_{15-16}$ : hótan málista génêtai kýklos kaì hótan béltistos; "quando <o movimento> se torna o mais circular, isto é, quando se torna o melhor"). Ora, o pneuma 
inato é um propagador ideal do movimento, na medida em que não está sujeito a nenhum outro movimento a não ser o movimento local, tal como nos corpos celestes que, conquanto só se movam circularmente, são responsáveis por todos os outros movimentos que acontecem na esfera sublunar. Em outros termos: tanto na Física quanto no De motu animalium constata-se a superioridade do movimento tópico circular sobre os demais tipos de movimento.

Mas, seria lícito ainda outra pergunta: seria mesmo o coração a causa última do movimento dos animais? Teríamos de responder negativamente, pois o coração constitui, juntamente com o pneuma e as articulaçôes somente a condição fisiológica necessária para a ocorrência do movimento e não a sua causa efetiva. Esta só pode se produzir, na perspectiva aristotélica, em função de sua causa final. Do mesmo modo que o cosmo não possui um contato físico com o Movente Imóvel, mas apenas aspira a esse como um fim, assim também o animal apenas tende para o bem, real ou aparente, a que aspira. Obviamente, o coração, por um lado, e o pneuma e as articulaçóes, por outro, constituem como que os analogados fisiológicos do cosmo e de Deus. Ou ainda, seguindo o modelo descrito na Física e readaptado ao De anima, eles são os instrumentos corpóreos por meio dos quais o animal é movido.

Todavia, no contexto de uma explicação finalística, como poderíamos ilustrar a ideia de que o télos funciona como arkhẹ . Ora, a citação do De anima que fizemos mais acima o comprova à exaustão. O fim aspirado pelo homem é o princípio da sua ação. Eis 
aqui enunciado mais uma vez, ainda que apenas implicitamente, o caráter circular da teleologia aristotélica. O bem a que aspiramos é o que nos incita a agir. Ele constitui a premissa maior do silogismo prático. A essa premissa deve-se apor uma premissa menor que diz respeito à possibilidade efetiva de realizarmos esse bem. Dessas duas premissas segue-se a ação que é o análogo, no âmbito do silogismo prático, à conclusão, no âmbito do silogismo teórico.

$\mathrm{Na}$ dimensão prática, a noção de fim perde, contudo, o seu caráter estritamente circular. Nela o télos corresponde ao skopós. Ou seja: o fim aspirado, ao não ser algo perfeito e eterno, mas apenas relativo e temporal, não pode ser pensado circularmente, ainda que a estrutura mesma do movimento o seja (isto é: o fim é, na verdade, o princípio do movimento). De modo análogo, como nos explica Aristóteles em outro texto, a eternidade dos animais ocorre somente no plano da espécie, mas não no plano do indivíduo (cf. De gen. et corrup. $\left.337 \mathrm{~b}_{5-7}\right)$. Em outras palavras: no domínio da espécie temos sempre um movimento circular (um homem gera um homem) ou, ao menos, um movimento que visa emular a circularidade dos corpos celestes, logo um movimento télico, isto é, completo, enquanto no domínio dos indivíduos temos um movimento atélico, isto é, incompleto e, portanto, linear. Isto quer dizer: um movimento sujeito a interrupçóes que nada mais são do que a sua geração e a sua corrupção (um homem gera, na verdade, outro homem, pois enquanto indivíduo ele é mortal, embora a espécie à qual pertença não o seja). 
Por fim, mas não em último lugar, Aristóteles nos esclarece que a existência de tendências contrárias só "ocorre nos que possuem percepção temporal" (De an. $433 \mathrm{~b}_{6-7}$ : ginetai d'en tô̂s khrónou aisthesin ékhousin), isso porque neles o intelecto manda resistir em vista do futuro e o desejo incita a atuar imediatamente. Ora, não fosse por essa capacidade de perceber o futuro, o homem não poderia resistir a um prazer imediato e esse é propriamente o caso dos indivíduos caracterizados como incontinentes, ou seja, dos indivíduos que são comandados por seu desejo e não por sua razão. Cabe ressaltar, entretanto, que estritamente falando não há percepção do tempo para Aristóteles. O que ocorre, de fato, é a percepção de diferentes posições ou estados de um ente móvel e simultaneamente a essa, a numeração desses dois momentos por meio do intelecto. Só assim podemos nos aperceber do tempo, caso contrário, não nos pareceria ter transcorrido tempo algum (cf. Phys. IV 11, $219 \mathrm{a}_{30-31}$ onde Aristóteles ilustra a sua tese por meio de um relato sobre uns indivíduos que ao terem adormecido tornaram-se incapazes de se aperceber da passagem do tempo).

Além disso, a percepção é sempre acompanhada de prazer e dor que se manifestam no plano fisiológico pelo aquecimento e resfriamento do organismo como um todo ou, ao menos, de parte dele, mas, na verdade, não é necessária uma sensação a fim de produzir alterações fisiológicas em um organismo, na medida em que uma simples imagem da coisa ou um pensamento sobre ela são suficientes para produzi-las. Essa é a razão porque experimentamos tremores ou nos sentimos 
excitados com a simples imagem ou ideia de algo que realmente nos amedronte ou excite como Aristóteles nos explica alhures (cf. De motu animalium $701 \mathrm{~b}_{16-22}$ ). Ora, isso significa que respondemos fisiologicamente tanto às recordações (mnệmai) quanto às expectativas (elpides) que temos sobre as coisas, o que só pode ocorrer, contudo, ao levarmos em consideração os diferentes modos do tempo - passado, presente e futuro (cf. De motu animalium $702 \mathrm{a}_{5-7}$ ). Por essa razão, no segundo livro da Retórica, Aristóteles procura definir as diferentes emoções que nós sentimos em relação à dimensão temporal que lhes é inerente. Assim, por exemplo, o medo (phóbos) e a confiança (thársos) só podem ser compreendidos em sua relação com o futuro (cf. Rhet. $1382 \mathrm{a}_{21-22}$ sobre o medo e Rhet. 1383 $\mathrm{a}_{16-19}$ sobre a confiança).

É interessante observar, por fim, como essa preocupação de salvaguardar os modos do tempo - o passado, o presente e o futuro - inexiste no tratado do tempo (Phys. IV, 10-14), onde, ao contrário, o Estagirita tenta eliminar essas diferenciações temporais triviais e cotidianas (passado, presente e futuro) e substituí-las pelos conceitos definidos quantitativamente de anterior-posterior e de um agora inextenso. No âmbito da ação humana, ou seja, no âmbito daquilo que pode ser de outro modo, é impossível, contudo, desconsiderar esses conceitos temporais qualitativos, pois eles se fundamentam na própria concepção modal implícita à diferenciação entre os tipos de substância postuladas por Aristóteles e, por essa razão, eles reaparecem sempre que ele se proponha a explicar a estrutura mesma 
da ação e da decisão humanas. Isso ocorre tanto na Ética Nicomaquéia quanto nos textos por nós aqui investigados e que se propóem, dentre outras coisas, a analisar o silogismo prático como o modelo segundo o qual toda ação humana ocorre.

Aristóteles, por conseguinte, diferencia claramente os fins e os meios de uma ação. O fim é o bem almejado e este é objeto do querer (boúlesis), os meios, entretanto, são objeto de decisão (proaíresis) e esta ocorre em um momento determinado e, caso decidamos corretamente em vista do fim, então teremos decidido no momento oportuno (kairós). Logo, é apenas graças à nossa consciência temporal que podemos deliberar corretamente, pois, caso não fôssemos capazes de deliberar sobre os fins, que se situam no futuro, seríamos incapazes de nos libertar do apelo do prazer imediato. Ou seja: a razão leva em consideração o futuro, onde se encontra o bem a que aspira, mas o desejo considera apenas o prazer iminente. Desse modo, o querer, que é a apetência racional, deve refrear o desejo, que é a apetência irracional, com o intuito de que este não se iluda com o iminente, mas tenha sempre diante de si o fim verdadeiro a que deve aspirar e que se encontra no futuro. Tampouco o passado, no caso do silogismo prático, interessa particularmente, porque, segundo Aristóteles, só pode haver deliberação ou decisão sobre o que é ou será possível, e o passado, ao contrário disso, possui um caráter necessitarista, avesso, portanto, a toda possibilidade (cf. EN $1139 \mathrm{~b}_{5-9}$ ). O passado parece então predominar no âmbito da ação apenas no caso em que predomina o impulso (thymós) gover- 
na a ação, pois, neste caso, o indivíduo não age nem quando nele predomina o desejo, ou seja, por causa do prazer iminente, nem como quando nele predomina a deliberação, isto é, em razão do bem futuro, mas apenas em função de um ultraje ou desprezo sofridos no passado. Assim, se o indivíduo que age em função de seu desejo não parece seguir nenhum silogismo, o impulsivo, por outro lado, parece de algum modo ouvir a razão, mas a ouve mal, pois esta, na verdade, não se ocupa do passado. O impulsivo age então como se seguisse um silogismo que afirmasse que devemos vingar as ofensas e injustiças de que fomos vítimas no passado, mas esta não é uma ação executada segundo um autêntico silogismo prático.

Vê-se, portanto, que para o Estagirita uma correta distinção dos modos temporais - passado, presente e futuro - é essencial no plano da ação, ainda que eles possam e, na verdade, devam ser desconsiderados para se empreender uma correta análise física do tempo, tal como aquela levada a cabo por Aristóteles no quarto livro de sua Física. 


\section{BIBLIOGRAFIA}

Aristoteles. Über die Seele, Mit Einleitung, Übersetzung (nach W.Theiler) und Kommentar herausgegeben von Horst Seidl. Griechischer Text in der Edition von W. Biehl u. O. Apelt, Felix Meiner Verlag, Hamburg, 1995.

Aristotle. De anima, With translation, introduction and notes by R.D. Hicks, Adolf M. Hakkert Publisher, Amsterdam, 1965.

Aristotle. De motu animalium, Text with translation, commentary, and interpretative essays by Martha C. Nussbaum, Princeton University Press, Princeton, 1985.

Aristotle. Parts of Animals. Movement of Animals. Progression of Animals, Translated by A.L. Peck and E.S. Forster, Harvard University Press, Cambridge (Mass)/ London, Loeb Classical Library, 1993.

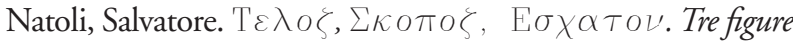
della storicità, Il Centauro, 5, maggio-agosto, 1982. 
Nussbaum, Martha. "The 'common explanation' of animal motion", in: Zweifelhaftes in Corpus Aristotelicum, Hrsg. P. Moraux u. J. Wiesner, Walter de Gruyter, Berlin, 1983.

Puente, Fernando. Os Sentidos do Tempo em Aristóteles, São Paulo, Loyola, 2001.

Verbeke, G. L'évolution de la doctrine du pneuma du Stoücisme à Saint Augustin, Louvain/Paris, 1945. 


\title{
OBSERVAÇÕES SOBRE O TEMPO NAS MEDITAÇÕES DE MARCO AURÉLIO
}

\begin{abstract}
uito embora Marco Aurélio não tenha nos lega1 do um tratado do tempo do porte das reflexôes mais densas acerca desse tema na Antiguidade (tais como as contribuiçóes de Aristóteles, Plotino e Agostinho), a onipresença da temática temporal perpassa todos os doze livros de suas Meditaçôes, com exceção obviamente do primeiro livro, de caráter eminentemente biográfico. Um outro dado interessante a ser ressaltado é que, em relação à concepção do tempo, a doutrina estóica não sofreu demasiadas alterações ao longo dos séculos, pois quando comparamos os esparsos fragmentos sobre esse tema que foram conservados do período helenístico com as diversas passagens que tratam desse assunto na obra de Marco Aurélio em pleno Império Romano, constatamos obviamente pequenas diferenças, mas podemos averiguar sobretudo uma profunda semelhança temática e doutrinal.
\end{abstract}


Um fragmento conservado por Estobeu (SVF II, 509) atribui a Crisipo algumas interessantes reflexôes acerca do tempo. Seguindo em parte a tradição aristotélica, mas evidentemente distanciando-se igualmente da mesma, Crisipo relaciona o tempo ao movimento definindo-o como o intervalo (diástéma) que acompanha o movimento do cosmo e afirmando que todos os entes se movem e existem de acordo com o tempo, asserçõos estas que, como se vê, estão em explícita oposição ao tratado do tempo do Estagirita no qual ele afirmava que o tempo é o número do movimento e que devido ao fato de apenas alguns entes se moverem, por conseguinte, apenas destes entes poder-se-ia dizer com exatidão que eles existem no tempo. Além disso, Crisipo afirma a infinitude das extremidades do tempo, a saber, do passado (parelelýthota) e do futuro (méllonta), opondo-os em bloco ao presente (enistatos khrónos), concebido, portanto, tal como nos confirma um passo em Diógenes Laércio (cf. Vida dos Filósofos Ilustres, VII, 141) como limitado. Constata-se então uma aporia (ao menos na visão de alguns intérpretes como, p.ex., Goldschmidt) em relação ao estatuto por ele conferido ao presente, pois Crisipo afirma, por um lado, que nenhum tempo é inteiramente presente, dado que ao ser um contínuo qualquer parte do mesmo pode ser dividida infinitamente, mas, por outro lado, que um tempo pode ser dito presente de acordo com a sua extensão. Ou seja: é como se ele negasse e, ao mesmo tempo, afirmasse a existência do presente. Todavia, apesar de ressaltar esse caráter problemático do presente, de acordo com ele, só o presente parece 
"existir" (hypárkhein), enquanto passado e futuro apenas parecem "subsistir" (hyphestánai). A questão é a de saber de que modo devemos interpretar e traduzir esses verbos e aqui há uma radical divergência entre as exegeses, propostas por Goldschmidt e por Hadot, à qual retornaremos mais adiante. Para Crisipo, só os atributos atuais parecem existir propriamente, não os potenciais. Ele nos oferece um exemplo: só existe o caminhar enquanto eu caminho, mas ao estar deitado ou sentado o caminhar inexiste para mim. Temos também aqui uma clara oposição ao modelo ontológicopredicativo aristotélico no qual o modo potencial é um modo válido de ser para um atributo.

Uma vez mencionada, em linhas gerais - e sem se deter em uma análise mais minuciosa - a posição de Crisipo, será possível comprovar, a seguir, em vários aspectos a semelhança de sua concepção com a de Marco Aurélio. É evidente, contudo, que essas semelhanças não significam uma identidade simples, pois mesmo dentre os estóicos da era imperial, filosófica e culturalmente tão mais próximos entre si, pode-se constatar uma diversidade de ênfase em relação ao problema do tempo. Assim, segundo Hadot, Marco Aurélio pode ser diferenciado de Epicteto pela constante insistência de sua parte para que os exercícios filosóficos, por ele propostos ao longo de seus livros, sejam realizados no presente (cf. Hadot, p.148). Deste modo, a disciplina do assentimento, por exemplo, deve focar a sua atenção na representação presente, a disciplina do desejo no evento presente e a disciplina do impulso na ação presente. Devemos, pois, circunscrevermo-nos ao pre- 
sente, porque, contrariamente a este, o passado e o futuro não dependem de nós. Eles devem, portanto, ser-nos indiferentes na medida em que nós só vivemos e agimos no presente em nossas vidas.

Ao realizar um levantamento de todas as passagens significativas para o nosso tema ao longo dos onze livros das Meditações de Marco Aurélio, constatamos que elas podem ser classificadas em dois grandes grupos temáticos estreitamente conectados: um que assinala a efemeridade da vida humana e o outro que reflete sobre a atenção que nós devemos conceder ao presente.

Vários dos pensamentos do célebre imperador estóico podem ser subsumidos no tópico "efemeridade da vida". Alguns deles tematizam isso diretamente, como, por exemplo, o IV, 48: “em geral, considera sempre as coisas humanas como efêmeras e de pouco valor" ou o VII, 1: "nada é novo, tudo é habitual e de pouca duração (oligokhrónia)". Essa duração escassa é também o objeto de reflexão de outra máxima: "A pouca duração (tò oligochrónion) é comum a todas as coisas, mas tu a todas foges e as busque como se fossem eternas (hós aiónia esómena)" (X, 34). Về-se, portanto, que a causa dos males humanos reside, segundo ele, em que os homens não aceitam essa efemeridade e transitoriedade de todas as coisas. Os homens agem, enfim, como se as coisas fossem eternas.

Poucos, contudo, são os pensamentos de Marco Aurélio voltados mais especificadamente para elucidar a questão teórica acerca do estatuto ontológico do tempo. Como, por exemplo, diferenciar khrónos e aión que aparecem contrapostos nas citaçóes acima? Em al- 
gumas de suas reflexôes, o aión é associado a um rio: "O tempo (ho aión) é um rio, o das coisas que devêm, um fluxo impetuoso" (IV, 43). Um outro pensamento, o VI, 15, esclarece um pouco melhor a noção de aión ao dizer que "fluxos e transformaçōes renovam o cosmo continuamente, como o movimento incessante do tempo (he tồ khrónou adiáleiptos phorà) produz sempre de novo o tempo infinito (tòn ápeiron aióna)". Ou seja: aión, que nós traduziríamos em um contexto platônico por eternidade, é constituído, para Marco Aurélio, pelo movimento incessante do tempo. Em outras palavras: ele é tão somente o tempo pensado em sua infinitude e não, por assim dizer, "o outro" do tempo, por isso é melhor traduzi-lo, no âmbito das Meditaçôes, por tempo infinito e não por eternidade. Conquanto não nos seja possível analisar, no âmbito deste texto, outro pensamento do nosso imperador filósofo, cabe mencioná-lo aqui, pois ele explicita essa íntima transitoriedade de todas as coisas por ele professada ao empregar a metáfora do rio não para falar do tempo, mas sim para falar da própria substância (ousía) que ele afirma ser "como um rio em contínuo fluir" (V, 23).

No seio dessa infinita transitoriedade resta-nos somente, segundo nosso imperador filósofo, ter sempre em mente a seguinte máxima: "recorda da substância total, da qual participas escassamente e também do tempo infinito total (tôิ sýmpantos aiônnos), do qual te foi designado um intervalo (diástẹma) breve e ínfimo" (V, 24; cf. também II, 4). Programaticamente, a atitude que deveríamos adotar diante da vida pode ser ilus- 
trada por meio de nossas reflexões acerca dos seguintes tópicos por ele mencionados sinteticamente no pensamento XII, 7: "a brevidade da vida, a imensidão do tempo infinito antes e depois de nós, a debilidade de toda a matéria”.

A constatação da brevidade da vida de cada um é assunto de inúmeras passagens das Meditações de Marco Aurélio (cf. II, 6; IV, 6; VI, 30, V, 24 e XI, 18 (6)) que tratam da efemeridade radical que acomete a todos nós e da celeridade com que deixaremos de estar vivos. Diante disso, segundo ele, resta-nos apenas a tarefa de agir como se devêssemos deixar a vida imediatamente (cf. II, 11), ou mesmo, ante o fato de que em breve estaremos mortos (cf. VIII, 2), agir como se já estivéssemos mortos (cf. VII, 56). De que modo, entretanto, pode-se alcançar tal grau de desprendimento? Por meio da meditação acerca da história universal e de alguns de seus exemplos, é a resposta de nosso imperador estóico. Várias das reflexões de Marco Aurélio relatam também sobre a efemeridade e transitoriedade de vários "mundos", por exemplo, o de Vespasiano e o de Trajano (cf. IV, 32) ou sobre a fugacidade da vida de homens ilustres como Pitágoras, Sócrates, Eudoxo e Arquimedes (cf. VI, 47). Esses exemplos visam sempre, na economia do brevíssimo texto de Marco Aurélio, enfatizar a ausência de novidade nos acontecimentos que ocorrem em nossas vidas. De acordo com ele, tudo se repete eternamente, tal como se repetiram os dramas nas cortes de Adriano, Antonino, Felipe e Alexandre; mudaram apenas os atores, como nosso imperador filósofo nos esclarece, mas as cenas e 
enredos foram, na verdade, sempre os mesmos (cf. X, 27). Em suma: logo tudo estará destruído e as próprias testemunhas dessa destruição, por sua vez, brevemente também estarão destruídas (cf. IX, 33). No mesmo sentido, ele afirma que enquanto muitos mortos não são nem por pouco tempo lembrados, outros são convertidos em lendas, mas estas próprias lendas também são ao fim e a cabo esquecidas (cf. VIII, 25). Nesse incessante devir em que vivemos, portanto, morrem, não só os médicos, que salvam os enfermos da morte, os astrólogos, que predizem os óbitos, os filósofos, que discutem sobre a imortalidade da alma e os tiranos, que têm poder sobre a vida e a morte de tantos, mas também as próprias cidades desaparecem para sempre da face da terra como Pompéia e Herculano, dentre inúmeras outras (cf. IV, 48).

É frequente o emprego da metáfora do ponto em Marco Aurélio para expressar a nossa pequenez e insignificância. Assim, a própria terra é comparada a um mero ponto em alguns pensamentos (cf. IV, 3 e VIII, 21) e, do mesmo modo, ele afirma, em outra de suas reflexões, que "o tempo da vida humana é um ponto" (II, 17), e que a própria vida humana é apenas uma fração do tempo infinito e imenso (cf. XII, 32), enfim, diante do tempo infinito o tempo humano não é quase nada, ou, como ele diz em outra de suas reflexóes, o tempo da vida humana é apenas "a torção de uma broca” (X, 17). Hadot comenta com muita pertinácia que Marco Aurélio com esses exemplos não visa afirmar que o presente seja realmente inexistente, caso contrário, ele incorreria em uma contradição ao afir- 
mar em outros pensamentos a existência do presente, mas apenas quer sinalizar que relativamente a essas grandezas quase incomensuráveis o presente é um quase nada. Essa seria a mesma aporia que, segundo alguns (p.ex. Goldschmidt), Crisipo incorre ao negar e, ao mesmo tempo, afirmar o presente. Para Hadot, no caso de Crisipo, trata-se tão somente de contrapor o presente ao passado e ao futuro, não de modo radical, como se o primeiro existisse e os outros não (que é, na verdade, o modo como Goldschmidt interpreta essa passagem), mas apenas enfatizando uma diferença temporal implícita nos verbos hypárkhein e hyphestánai, dado que ambos para Hadot significam "existir" (enquanto Goldschmidt propõe "existir" e "subsistir" como tradução para esses verbos). O primeiro verbo, para Hadot, possuiria um valor incoativo e durativo, o segundo, um valor definitivo. Isto é: o presente é aquilo que depende de nós enquanto nós o vivemos; passado e futuro não dependem de nós, pois já estão determinados. Claro que aqui é necessário pressupor, de acordo com a doutrina estóica, que o futuro está tão determinado quanto o passado, pois o destino por ela postulado desconhece um e outro. Por fim, para Hadot, Marco Aurélio, em consonância com Crisipo, não estaria incorrendo em nenhuma contradição, antes estaria defendendo em suas Meditações apenas um único sentido do presente, a saber, o de um tempo incoativo e durativo no qual podemos e devemos agir (cf. Hadot, pp. 153-4).

É a contemplação da infinitude do passado e do futuro, por conseguinte, que nos faz constatar a nossa 
insignificância como nos testemunham inúmeros de seus pensamentos (cf. IV, 3; IV, 50, IX, 32 eXI, 1). Essas consideraçôes visam evidenciar a ausência de novidade em todo esse processo de transformação universal, de modo que tanto faz, segundo Marco Aurélio, viver muito ou pouco, pois se bem observado e meditado, tudo é igual, e nada há ou haverá de novo. $\mathrm{O}$ que devemos fazer então é exercitar nosso olhar sobre o mundo de modo a obedecer ao imperativo que nosso imperador filósofo nos oferece: "Atento a cada coisa, pensa que ela já está se dissolvendo e que já se encontra em transformação, como, por exemplo, em decomposição ou dispersão, ou de que modo cada uma nasceu como que para morrer" (X, 18). A prática desse método deveria nos levar então ao estado que ele descreve em outra meditação: "Assim verás continuamente que as coisas humanas são fumo e nada, sobretudo se te lembrares conjuntamente que uma vez que algo mudou, não estará mais no tempo infinito (en tôi apeíroi khrónoi). Por que, pois, esta tensão? Por que não te contentas em passar esse breve instante de modo conveniente (kosmíos)? De que matéria e de que hipótese foges? Que é tudo isso senão exercícios da razão (gymnásmata lógou) que viu com precisão de naturalista as coisas que ocorrem na vida? Persiste então, até que tenhas assimilado tudo isso, como um estômago forte tudo assimila, como um fogo ardente produz fogo e luz do que quer que lhe atirem" (X, 31).

A assimilação dessa observação deveria nos conduzir então não a um conformismo, mas sim a uma ação piedosa e justa, pois como o próprio Marco Aurélio 
nos adverte: "A vida é breve. O único fruto da vida sobre a terra é uma disposição piedosa e a prática do bem comum" (VI, 30). Ou em outro pensamento: "Assim, uma só coisa é digna de valor: passar a vida com verdade e justiça e benévolo com os mentirosos e injustos" (VI, 47). Ou ainda, enfatizando a necessidade dessas duas atividades: "agir justamente nas açôes que agora executa e amar o que agora lhe foi designado" (X, 11). Depreende-se dessas passagens que o que Marco Aurélio quer dizer com disposição piedosa ou amar o que acontece, nada mais é do que o exercício da disciplina do desejo, ou seja, devemos nos exercitar na aceitação voluntária do que nos acomete e que a prática do bem comum nada mais é do que o exercício da disciplina da ação que nos leva a agir em função da comunidade humana, isto é: a agir com verdade e justiça.

É exatamente visando essa possibilidade de ação no presente que são escritos vários pensamentos de Marco Aurélio que nós agrupamos em outro grande bloco temático, como dissemos acima, e que poderia ter por título "a atenção ao presente". Como ele mesmo afirma, o melhor momento para filosofar é precisamente aquele em que agora nos encontramos (cf. XI, 7). Sendo assim, o que devemos observar, então, é o ritmo correto da natureza do qual não podemos nos apartar sob pena de perdermos nossa serenidade, pois, em suas palavras: "quando a coação das circunstâncias te deixar como que perturbado (diatarakhthênai), retorna depressa a ti mesmo e não sai do ritmo além do necessário, pois serás tanto mais senhor da harmonia ao regressar continuamente a ela" (VI, 11). A contem- 
plação dessa harmonia e desse ritmo universais, por conseguinte, deveriam nos conduzir paulatinamente a agir e pensar de acordo com eles.

$\mathrm{Se}$, com o intuito de constatar a efemeridade de nossa vida, a contemplação da infinitude do passado e do futuro era necessária, a atitude a adotar para que possamos atentar somente para o presente é a de desprezo e desconsideração pelo passado e pelo futuro. Isso ocorre porque só podemos propriamente deixar de viver o presente, não o passado ou o futuro (cf. II, 14), pois é apenas no presente que vivemos efetivamente (cf. III, 10). Sendo assim, a reta ação é a de circunscrever-se ao presente (cf. VII, 29) dispondo bem do mesmo (cf. VI, 2), a fim de aproveitá-lo de modo razoável e justo (cf. IV, 26). Em outras palavras: não devemos agir como se fôssemos viver dez mil anos (cf. IV, 17), mas sim executar a todo o momento (hora) cada ação como se fosse a última (cf. II, 5). E devemos compreender, como nos explica Marco Aurélio, que não é o passado que nos aflige mas sempre o presente (cf. VIII, 36). Tampouco devemos temer o futuro (cf. II, 2) ou nos perturbar com ele (cf. VII, 8), pois é preciso que cuidemos de viver apenas o que estamos atualmente vivendo, a saber, o presente (cf. XII, 3).

Deste modo, sem nos preocuparmos em querer saber quantos anos ainda viveremos (cf. VI, 49), nosso dever é o de saber que, como nos enuncia Marco Aurélio, "a natureza nos concederá o momento oportuno (kairón) e o limite" (XII, 23). Mas, diante disso, poder-se-ia perguntar: como saber se o que a natureza nos traz agora é realmente oportuno? A resposta de 
Marco Aurélio é bastante precisa, como o breve pensamento X, 20 ilustra: "a cada um convém o que a natureza universal traz, e isso convém quando ela o traz". Donde se segue que tudo que ocorre no bom momento (eúkairon) é um bem (cf. XII, 35), mas dado que tudo ocorre quando a natureza quer, então tudo o que nos ocorre é um bem, pois tudo o que nos acomete, ocorre em um bom momento.

Vimos que as disciplinas do desejo e a da ação estão presentes de modo explícito nas Meditações. Mas, e a disciplina do assentimento? Ela estaria ausente dessas reflexões relativas ao tempo? Não. Até mesmo a disciplina do assentimento está presente nessas considerações, ainda que de modo menos explícito. Recordemo-nos de que Marco Aurélio afirma explicitamente no pensamento VII, 29: "Suprime a representação... circunscreve o tempo presente (perígrapson tò enestòs tôิ khrónou)". Essa supressão da representação diz respeito exatamente à disciplina do assentimento, que nesse caso se refere a limitar-se tão só àquilo que depende de nós. E a única coisa que depende de nós, como vimos, é o presente, pois passado e futuro já estão determinados. Sendo assim, fica fácil compreender a intenção por trás dos exemplos nos quais Marco Aurélio chama a nossa atenção para o fato de não desejarmos que as coisas durem eternamente (cf. X, 34) ou que vivamos dez mil anos (cf. IV, 17). Ou seja: a disciplina do assentimento está diretamente associada à diferenciação entre o que depende e o que não depende de nós, e reside exatamente nisso a distinção entre o presente, que depende de nós, e o passado e 
o futuro, que não dependem. A intenção de Marco Aurélio com esses exemplos é, na verdade, a de nos oferecer uma correta representação do tempo, ou seja, uma phantasìa kataleptiké referente ao fenômeno temporal. Isso só é possível por meio de uma adequada descrição física do mundo e, no nosso caso em particular, de uma detalhada análise do caráter temporal do mesmo, em outros termos, da constatação de sua radical efemeridade, fragilidade e brevidade.

Vemos, portanto, que todas as disciplinas, a do assentimento, a do desejo e a da ação, que compõem a trama conceitual das Meditaçóes estão presentes nesses pensamentos e reflexões acerca do tempo, evidenciando-nos assim que a análise magistral de Hadot, oferecida por ele em sua obra consagrada a Marco Aurélio, La citadelle intérieure, nos oferece de fato uma profícua e incontornável chave de leitura que nos permite adentrar com segurança, por vários caminhos e veredas, nos recônditos mais íntimos dessa cidadela interior esculpida com tanto cuidado e esmero por nosso imperador filósofo e que, apesar de sua quase pessimística crença acerca da efemeridade de todas as coisas, permanece solidamente inalterada até os nossos dias como um testemunho autêntico de sua argúcia e bom senso filosóficos. 
(Página deixada propositadamente em branco) 


\section{BIBLIOGRAFIA}

\section{FONTE PRIMÁRIA}

H. von Arnim, Stoicorum Veterum Fragmenta, Lipsia 1903-1905; ed. anast. Stuttgardie, 1964 (4 vols.).

Marco Aurélio. Pensieri, a cura di Maristella Ceva, Milano: Mondadori, 1989.

Marco Aurélio. Meditaciones, trad. Bartolomé Segura Ramos, Madrid: Alianza, 1985.

Marco Aurélio. Meditaçôes, trad. Jaime Bruna, São Paulo: Cultrix, 1964.

\section{BIBLIOGRAFIA SECUNDÁRIA}

Bréhier, E. La théorie des incorporels dans l'ancien stoicisme, Paris: Vrin, 1997. 
Goldschmidt, V. Le système stoicien et l'idée de temps, Paris: Vrin, 1977.

Hadot, P. La citadelle intérieure. Introduction aux Pensées deMarc Aurèle, Paris: Fayard, 1997. 


\title{
O TEMPO E A ALMA
}

\author{
UM ESTUDO COMPARATIVO ENTRE \\ ARISTÓTELES E PLOTINO
}

s dois textos mais importantes sobre o tempo que
a Antiguidade, no âmbito da Filosofia Grega nos
legou (prescindimos aqui, portanto, da fundamental
análise de Agostinho sobre o tempo e a alma contida
no Livro XI das Confissões), são o tratado do tempo
de Aristóteles (Phys. IV 10-14) e o tratado sobre a
eternidade e o tempo de Plotino (En. III 7, 1-13). É
óbvio, porém, que para ter um pleno entendimento
desse último texto, é preciso inscrevê-lo na tradição
que remonta a Parmênides e mais diretamente a Pla-
tão. Plotino analisa o tratado do tempo de Aristóteles
(especialmente em En. III 7,9 ), mas o rejeita. O Es-
tagirita, bem como Epicuro e Zenão, todos eles, se-
gundo Plotino, fracassaram ao tentar explicar o tem-
po, pois nunca investigaram a sua essência enquanto
tal, analisando-o apenas em sua relação com outros
itens, tais como: o movimento (kinesis), o número
(arithmós), a consequêncialidade (parakoloúthenema), a 
extensão (diástẹma), etc. Plotino quer mais, ele aspira explicar a própria essência do tempo, ou seja, ele pretende mostrar o que o tempo é considerado em si mesmo e não o que ele é em relação a outra coisa. Para isso, entretanto, é necessário, segundo ele, perguntar o porquê do tempo ter sido gerado e conhecer de onde ele provém. Só então será possível, em sua opinião, ter uma plena compreensão do tempo.

Desses dois textos fundamentais para o entendimento do conceito do tempo, investigaremos mais minuciosamente apenas a relação, neles discuti$\mathrm{da}$, entre a alma e o tempo. Obviamente, as enormes diferenças existentes entre as filosofias de Aristóteles e Plotino nos obrigarão primeiramente a analisar, em linhas gerais, as suas respectivas posições relativas a esse vínculo entre a alma e o tempo separadamente e só posteriormente a esboçar uma comparação entre elas.

\section{O TEMPO E A ALMA EM ARISTÓTELES}

A relação da alma com o tempo só é mencionada por Aristóteles no último capítulo do tratado do tempo, a saber, em Phys. IV 14, $223 \mathrm{a}_{16-29}$. É interessante observar que nessa curta passagem o Estagirita não se pergunta se existe (ei estín) ou não uma relação entre a alma e o tempo, mas apenas, pressuposta a sua existência, como (pos) ela deve ser entendida. Nos capítulos anteriores do tratado do tempo, ele já havia feito duas mençóes explícitas à alma, a primeira em $218 \mathrm{~b}_{31}$ e a segunda em $219 \mathrm{a}_{27}$. Averiguemos, pois, o contexto em que ocorrem essas referências explícitas à alma e 
em que medida elas se relacionam à passagem supracitada do capítulo catorze.

A primeira referência à alma ocorre logo após o relato sobre os indivíduos que teriam adormecido no interior de um templo consagrado a alguns heróis locais na Sardenha e que, ao despertarem, não tinham consciência alguma do tempo que havia transcorrido, pois eles uniam o agora em que adormeceram ao agora em que despertaram, privando-se, por conseguinte, da percepção do intervalo do tempo determinado por esses dois agoras, na realidade, diversos entre si, mas que eles ilusoriamente supunham ser idênticos. Desse relato, Aristóteles extrai duas possíveis consequências teóricas: a) se o agora não fosse diverso de um outro agora, sendo sempre o mesmo, então não existiria o tempo e b) se, por algum motivo, essa diversidade dos agoras permanecesse oculta para nós, então não pareceria existir um tempo intermediário entre esses dois agoras. Note-se a diferença dessas duas consequências: a primeira, caso se verificasse, negaria a própria existência do tempo (hipótese ontológica), já a segunda nega apenas o nosso conhecimento do transcurso de um intervalo de tempo (hipótese epistemológica). Esse é o caso dos dormentes da Sardenha e o caso que interessa Aristóteles, dado que a hipótese mais forte, aquela da não existência do tempo implicaria também a não existência do movimento, na medida em que o movimento, para o Estagirita, só pode ocorrer no tempo (cf. Phys. $235 \mathrm{a}_{11 \text { ss. }}$ ). Por essa razão, essa hipótese lhe parece totalmente absurda, porquanto para ele a existência de entes em movimento é por si mesmo 
evidente, não carecendo de demonstração alguma. Donde Aristóteles concluir que a convicção de que não existe tempo ocorra quando nós não distinguimos mudança alguma (interna ou externa) e então "a alma parece permanecer no mesmo e indivisível <estado>" (Phys. IV 11, $218 \mathrm{~b}_{31 \mathrm{~s}}$ : en henì kaì adiarétoi phainetai he psykhè ménein). Ao contrário, quando percebemos e determinamos os agoras, segundo a sua anterioridade ou posterioridade, então dizemos que transcorreu um intervalo de tempo.

A ocorrência do termo alma em $219 \mathrm{a}_{27}$ está em estreita relação com o passo anterior e constitui, por assim dizer, a sua explicação. Aristóteles afirma que a nossa percepção do tempo ocorre "quando nós pensarmos os extremos diversos do meio e a alma dizer serem dois os agoras, um o anterior, outro o posterior, então dizemos isto ser tempo" (Phys. IV 11, $219 \mathrm{a}_{26-29}$ : hótan gàr hétera tà ákra tôิ mésou noésomen, kaì dýo eípei he psykhè tà $n$ n, tò mèn próteron tò d'hýsteron, tóte kaì toûtó phamen eînai khrónon). A condição necessária para a percepção do tempo é a constatação da existência de dois agoras diversos entre si, bem como diferentes do que os separa, a saber, um intervalo de tempo. A diversidade dos agoras, por sua vez, se estabelece de acordo com a sua anterioridade ou posterioridade. Cumpridas essas condiçôes, podemos legitimamente falar de tempo. Atente-se para o termo "dois", pois ao analisarmos, a seguir, a passagem mais importante e extensa concernente à relação entre a alma e o tempo, essa referência explícita a um número adquirirá a sua plena significação. 
O texto mais importante para nós é, por conseguinte, o $223 \mathrm{a}_{16-29}$. Nele o Estagirita se preocupa em investigar como (poss) o tempo se relaciona com a alma. Consoante o que já havíamos observado anteriormente, essa relação é pressuposta por Aristóteles, restando a ele apenas a tarefa de saber como ela se articula. A pergunta que preside as suas considerações aqui é a de saber se haveria ou não o tempo, caso não existisse a alma. A articulação entre a alma e o tempo faz-se então, segundo nosso autor, por meio do número. Recordemo-nos de que ao final do capítulo onze do tratado do tempo, que juntamente com o capítulo dez forma um bloco argumentativo homogêneo e coeso, Aristóteles já havia enunciado a sua definição do tempo como "número de um movimento segundo o anterior-posterior" (Phys. IV 11, $219 \mathrm{~b}_{1-2}$ : arithmòs kinéseọs katà tò próteron kaì hýsteron). O conceito de número é, por conseguinte, essencial para se entender o tempo. Nesse passo da Física, que estamos analisando aqui, o Estagirita nos esclarece apenas que um número pode ser numerado (arithmoúmenon) ou numerável (arithmetón) e que a única faculdade naturalmente (pephỳken) capaz de numerar é a alma, mais precisamente o intelecto da alma (psykhess nous). Note-se que o que está em jogo nesse passo não é a alma em sua totalidade, mas apenas a sua função intelectiva. Essa íntima associação entre o intelecto e o número pode se depreender de uma passagem pouco investigada do De anima que afirma o intelecto ser um (heîs) e contínuo (synekhés), assim como o pensamento (nóésis) e as coisas pensadas (tà noémata), e que estas últimas 
formam uma unidade por meio da sucessão, tal como o número e não como a grandeza (cf. De an. $407 \mathrm{a}_{6-9}$ ). Há, portanto, um íntimo paralelismo entre a sucessão de pensamentos e a sucessão numérica. Ambas essas sucessões são discretas e não contínuas. Estamos aqui no âmago mesmo da física aristotélica, pois a própria possibilidade de conhecimento do mundo físico fundamenta-se, para ele, nessa associação entre as quantidades discretas e as contínuas, sendo que ambas são irredutíveis entre si.

Vejamos mais detidamente como tudo isso se articula conceitualmente nesse importante passo que estamos analisando. Aristóteles afirma que na ausência de um ente capaz de numerar não poderia haver nem algo numerável nem mesmo números (cf. Phys. IV 14, $\left.223 \mathrm{a}_{22-24}\right)$. Duas linhas depois, ele reitera essa opinião ao afirmar que "é impossível haver tempo não existindo alma” (Phys. IV 14, $223 \mathrm{a}_{26}$ : adýnaton eînai khrónon psykhês mè oúsess). A questão que se põe para nós, portanto, como já havia se colocado para inúmeros exegetas do passado, é a de saber em que medida o tempo depende da alma. Historicamente os intérpretes tenderam quer a desprezar essa relação do tempo com a alma (posição realista) quer a sobrevalorizá-la (posição idealista) ou, por fim, o que nos parece uma interpretação mais adequada, a tentar ver nela uma dependência parcial do tempo em relação à alma (posição moderadamente realista ou fenomenológica).

Sigamos os passos de Aristóteles nessa sucinta, mas densa passagem. Ele afirma, primeiramente, que o número pode ser ou o número efetivamente nume- 
rado ou o número que pode ser numerado, ou seja, o numerável. Como ocorre com frequência ao nos confrontarmos com dificuldades no pensamento do Estagirita, é ao binômio ato/potência que devemos tentar dirimir essas dificuldades. Mas, se o tempo é o número do movimento, estaria também este em dependência com a alma? Evidentemente que não, pois o movimento, mais precisamente ainda, os entes móveis, existem independentemente de serem ou não numerados. O movimento é, portanto, como que uma espécie de substrato do tempo - o que Aristóteles procura exprimir com a locução grega que ele constrói hò pote ón -, mas não o tempo em seu ser (tò eînai). Por isso, o Estagirita afirma, ao final do passo aqui em questão, que o anterior-posterior existe no movimento, mas o tempo é esse anterior-posterior apenas na medida em que ele é numerável (cf. Phys. IV 14, $223 \mathrm{a}_{28-29}$ ). Em outras palavras: o anterior-posterior de uma série cinética qualquer ainda não é propriamente o tempo, mas é apenas o seu quase substrato. Digo quase substrato porque o movimento ele mesmo não é um ente, não é uma substância, mas sim uma afecção que ocorre com alguns tipos de substância. O ser do tempo só se manifesta, entretanto, quando esse anterior-posterior de uma série cinética é efetivamente numerado pelo intelecto humano ou, ao menos, na sua relação de poder ser numerado, ou seja, quando o anterior-posterior é analisado em sua intrínseca potencialidade de receber um atributo numérico por parte do intelecto humano.

Em outras passagens do tratado do tempo Aristóteles ilustra com alguns exemplos o seu conceito de 
número. Quando determinamos por meio de um número, digamos o "dez", dois diferentes agrupamentos de seres vivos, por exemplo, um rebanho de ovelhas e uma matilha de cães, o dez que usamos para numerar esses conjuntos de entes é o mesmo, mas os elementos que constituem esses conjuntos obviamente são diferentes, pois uns são ovelhas e os outros, cães. Sucede algo análogo ao se numerarem distintos movimentos: o número deles, digamos o "três", é o mesmo, mas os movimentos, por exemplo, um movimento local de um animal e um processo de germinação de uma planta são obviamente distintos. Todavia, a pergunta que nos surge imediatamente no espírito é: Três o quê? Três horas, três dias, três semanas ou três meses? Bem, esse é um outro problema que Aristóteles percebe e soluciona no tratado do tempo, mas que no âmbito deste nosso texto não pode ser senão mencionado. É o problema da "objetividade" do tempo, como nós diríamos desde a Modernidade, ou da koinonía do tempo, como diriam os gregos da época de Aristóteles. Esse aspecto comum ou objetivo do tempo, portanto, só pode ser adquirido se o tempo for ele mesmo mensurado por um movimento, mas esse movimento deve ser sem interrupção, logo, homogêneo e de velocidade constante; caso contrário, ele não garantiria um padrão de medida comum ou objetivo. Esse movimento padrão, como se sabe, é para Aristóteles o movimento circular das esferas celestes ao redor da Terra. O movimento do Sol ao redor da Terra constitui, segundo as concepçôes cosmológicas vigentes à época, o ano, já o das estrelas fixas, o dia. São esses padrões comuns 
ou objetivos de medida que são a seguir numerados conforme o número de vezes que eles se aplicam a um dado movimento. Assim poderemos dizer, sem o perigo de incorrer em uma arbitrariedade inconsequente, que um dado movimento demorou "três dias" ou "três anos”. Note-se que, não por acaso, essa problemática da mensuração "objetiva" do tempo pelo movimento circular dos corpos celestes ao redor da Terra só encontra a sua solução no último capítulo do tratado do tempo (cf. Phys. IV 14, $223 \mathrm{~b}_{12}-224 \mathrm{a}_{2}$ ), capítulo, este, que, como estamos vendo, também apresenta as ideias mais explícitas de Aristóteles acerca da relação entre o tempo e a alma. É como se Aristóteles quisesse, por um lado, enfatizar a singular relação entre o intelecto humano e o tempo, mas, por outro, fizesse questão de assinalar a "objetividade", ou seja, a não arbitrariedade do tempo em relação aos homens.

O tempo, por conseguinte, parece ser constituído para Aristóteles por uma sutil inter-relação entre o movimento e a função intelectiva da alma. O primeiro é a condição necessária, mas não suficiente para que o tempo se manifeste em seu ser próprio. A fim de que isso ocorra, faz-se mister analisar a relação - potencial ou atual - do intelecto humano com um dado movimento, pois o intelecto, segundo o Estagirita, é a única instância no homem capaz de numerar um movimento. A capacidade de numerar parece ser um atributo próprio do homem e alguém poderia querer defini-lo - ainda que para o Estagirita essa não fosse propriamente uma definição, pois prescindiria do gênero, no caso, homem, que, segundo ele, deve ser o 
primeiro termo de uma definição - como "o que sabe numerar" (cf. Top. $142 \mathrm{~b}_{25-26}$ : tò epistámenon arithmeîn). A tensão que subjaz a essa inter-relação parece ser a mesma que se encontra entre o contínuo (o movimento) e o discreto (o número), pois o ser do tempo é uma complexa mistura entre a continuidade da grandeza percorrida pelo ente em movimento e a sucessão discreta dos números que expressa e determina o quantum do movimento ocorrido. Segue-se daí a caracterização do tempo por Aristóteles como sendo um contínuo sucessivo, dado ele não ser simplesmente um movimento (que é um contínuo) ou um número (que é sucessivo), mas sim o número de um movimento (que é então uma sucessão contínua). Em outras palavras: o conceito de tempo de Aristóteles parece ser a expressão mesma, no plano quantitativo, da díade lógico-ontológica ato/potência, pois a atividade intelectual de numerar um movimento parece corresponder logicamente à potencialidade ontológica que esse movimento tem de receber um atributo numérico.

\section{O TEMPO E A ALMA EM PLOTINO}

Antes de analisar a relação do tempo com a alma em Plotino, cabe fazer uma observação sobre a diferença fundamental entre o texto de Plotino e o de Aristóteles. $\mathrm{O}$ tratado de Plotino não estuda o tempo isoladamente, antes ele parte do pressuposto de que este só é plenamente compreensível a partir da eternidade (aión). Daí o título do seu tratado, atribuído, na verdade, por Porfírio ser: sobre a eternidade e o tem- 
po. A sua aproximação à questão do tempo é, por assim dizer, genética e não meramente descritiva, como ele julgava ser a de Aristóteles. Plotino quer saber, antes de tudo, de onde provém o tempo. E essa resposta, para ele, já havia sido dada por Platão no Timeu ao formular a definição do tempo como "imagem do eterno que procede segundo o número" (Tim. $37 \mathrm{D}_{6-7}$ : kat' arithmòn ioûsan aiónion eikóna).

É importante observar que essa definição de Platão foi interpretada de modo diverso pelos pensadores cronológica e teoricamente mais próximos de Platão, como Aristóteles e os seguidores imediatos de Platão na Academia e pelos neoplatônicos que viveram alguns séculos depois. Os primeiros pensavam, segundo mostra a exegese - que nos parece bastante interessante - de R. Brague, que essa definição referia-se mais propriamente ao céu e não ao tempo (cf. p.ex. Phys. 218 $a_{32}-219 b_{1}$ ), enquanto os segundos, seguindo uma tradição exegética que remonta a Albino (séc. II d.C.), Aécio (séc. II d.C.) e Diógenes Laércio (séc. III d.C.), perpetuaram a ideia de que "imagem do eterno" corresponderia à definição do tempo e não à do céu que, de acordo com R. Brague, seria a autêntica definição platônica, como pode ser depreendido do passo supracitado da Física de Aristóteles, bem como das opinióes de outros seguidores imediatos de Platão. Não é nosso objetivo aqui, entretanto, estendermo-nos nas razóes da origem dessa leitura equívoca de Platão, pois sobre isso o leitor interessado poderá consultar o minucioso ensaio de R. Brague, mas apenas constatar a sua presença (literal ou não) recorrente no texto de Plotino 
que estamos investigando (cf. p.ex. En. III, 7, 1, 19; III, 7, 11, 20 e III, 7, 13, 24).

Essa interpretação do tempo como "imagem móvel do eterno" é essencial para Plotino, porquanto o seu tratado, diversamente do de Aristóteles, não se ocupa só do tempo, como já dissemos, mas começa analisando a eternidade (cf. En. III, 7, 2-6). Essa ordem de discussão desses dois itens não é arbitrária, pois reflete, para Plotino, a própria ordem "ontológica” existente entre essas duas realidades, a saber, entre a eternidade e o tempo. A eternidade é o fundamento do tempo ou, dizendo de modo diverso, o tempo nasce da própria eternidade e isso é assim para Plotino, porque a Alma (terceira hipóstase) é gerada pelo Intelecto (segunda hipóstase). $\mathrm{Na}$ verdade, o mais adequado no caso do pensamento de Plotino é falar de ordem henológica (derivada de "um", em grego hén) e não ontológica (derivada de "ente", em grego ón) como fizemos pouco acima. Isso porque é a partir do Um (primeira hipóstase) que tudo se origina e é para Ele (o Um) que tudo converge ao aspirar retornar à sua Origem (esse movimento de retorno à Origem Plotino denomina epistrophé).

Na parte do tratado que se ocupa do tempo (cf. En. III, 7, 7-13), aparecem referências explícitas à relação entre o tempo e a alma em quatro capítulos, a saber, nos capítulos nove, onze, doze e treze. Detenhamonos então, respeitando o propósito inicialmente declarado deste texto, apenas na análise dessas passagens.

A primeira delas já comprova a distância que há entre a posição de Plotino e a de Aristóteles. O nono capítulo é precisamente o lugar onde Plotino analisa e 
critica a já célebre definição do tempo formulada pelo Estagirita como "número de um movimento segundo o anterior-posterior”. Retornando à pergunta do próprio Aristóteles acerca da possibilidade de haver tempo sem a alma intelectiva capaz de numerá-lo, Plotino se questiona ironicamente por que não haveria de existir tempo antes que houvesse a alma capaz de mensurá-lo e deduz que isso só poderia ser assim "a menos que alguém dissesse sua origem ter-se originado da alma" (En. III, 7, 9, 78-79: ei mé tis tèn génesin autôे parà psykhês légoi ginesthai). O termo "alma" deve ser entendido aqui como se referindo à alma individual e não à Alma do Mundo ou à Alma enquanto hipóstase. Plotino não vê qualquer necessidade de que preexista uma alma individual a fim de que ocorra a mensuração do tempo, pois, para ele, o tempo tem a mesma medida independentemente de que alguém o mensure ou não. Ele acredita que se poderia dizer corretamente acerca da alma que ela se utiliza da grandeza para medir, mas finaliza esse passo se perguntando atônito, o que isso teria a ver com o conceito de tempo (cf. En. III, 7, 9, 78-84).

No capítulo onze encontramos uma passagem fundamental para o nosso estudo. Nesse capítulo, onde Plotino começa a dar a sua própria resposta ao enigma do tempo, ele nos explica como ele concebe essa relação entre a alma e o tempo. Para poder compreender essa relação, contudo, é necessário entender a relação que ele postula haver entre o Um, o Intelecto e a Alma. Expliquemos então, ainda que sucintamente, essa relação. 
O Um, também denominado o Bem (cf. En. II, $9,1,5)$, fonte e origem de toda vida e de todo pensamento (cf. En. III, 8, 9, 38) situa-se para Plotino além de qualquer possibilidade de ser pensado, pois o pensamento, segundo ele, já implica na divisão entre pensante e pensado (cf. En. V, 6, 4, 1-5). Logo, o Um é diferente do Movente Imóvel de Aristóteles, pois do Um tampouco se pode dizer propriamente que Ele pense a si mesmo, o que, como se sabe, é o modo tradicional de Aristóteles caracterizar o Movente Imóvel (cf. En. VI, 9, 6, 49). Nada, pois, pode ser dito positivamente acerca do Um, apenas podemos afirmar, de modo negativo, que Ele é diverso de todas as outras coisas. Mesmo se dissermos que Ele é o Um e o Bem já é para Plotino dizer demais (cf. En. V, 3, 11, 24 e V, 5, 6, 34). Seus atributos positivos (que são mencionados, p.ex., em $E n$. VI, 8) devem ser concebidos então sempre como metáforas, pois que, em última instância, Ele é inefável e inexprimível (cf. En. V, 5, 6, 24 e En. VI, 8, 8, 6).

O Intelecto, que se origina do Um, é a segunda hipóstase do sistema de Plotino. O Intelecto plotiniano é idêntico ao Movente Imóvel de Aristóteles, porquanto ele é pensamento de seu próprio pensamento; este é o seu sentido mais próprio (cf. En. V, 3, 13, 14; uma menção explícita a Aristóteles se encontra em En. $\mathrm{V}, 1,9,8)$. Já há, portanto, nesse ato de pensar a si mesmo, de acordo com Plotino, a presença de uma dualidade (por um lado o que pensa, por outro o que é pensado). Ao Intelecto Plotino atribui as cinco categorias expostas por Platão no Sofista (cf. Soph. 254 D - 255A), a saber: essência (ousia), movimento (kinesis), 
repouso (stásis), o mesmo (tautón) e o outro (tháteron) (cf. En. III, 7, 3, 7-11). Atente-se para o fato de que Plotino desloca o conceito de movimento para um plano, o do Intelecto, no qual Aristóteles só postula haver ato puro e não movimento, pois para o Estagirita o movimento é algo imperfeito e inacabado, mais precisamente é a atualidade de uma potência enquanto potência (cf. Phys. III 1-3). Dado que o Intelecto é eterno, mas precisamente, devido ao fato de ele ser a própria eternidade (cf. En.V, 1, 4, 17-18), sendo que nele tudo "é" e que nada propriamente "foi" ou "será" (cf. En. III, 7, 3, 23-26 e VI, 1, 4, 21-26), é preciso excluir dele qualquer relação com o tempo, pois ele se situa fora de qualquer tempo, na medida em que este se expande, mas a eternidade permanece sempre idêntica a si mesma. Plotino ilustra essa relação do tempo com a eternidade por meio da relação geométrica existente entre a circunferência e o seu centro imóvel, dado que a linha do círculo parece estender-se infinitamente, mas, na verdade, ela depende do ponto imóvel ao redor do qual ela gira sem cessar (cf. En. VI, 5, 11, 14-21). A eternidade, portanto, é a vida do Intelecto, que é homogênea, plena e absolutamente inextensa (cf. En. III, 7, 3, 36-38).

Resta-nos falar da Alma, produzida pelo Intelecto, que é a terceira hipóstase do sistema plotiniano. A Alma, para Plotino, pode ser considerada de três modos: como hipóstase propriamente dita, como Alma do Mundo e, por fim, como alma individual. As almas individuais, entretanto, não devem ser entendidas como sendo partes da Alma do Mundo (cf. 
En. IV, 3, 1-2), pois elas, na verdade, são quase idênticas a essa, dado que ambas originam-se igualmente da Alma hipóstase, possuindo entre si, portanto, uma relação fraternal. Há, na realidade, apenas a Alma como princípio organizador da vida do organismo, seja esse organismo um organismo individual, seja ele o mundo em sua totalidade. No primeiro caso, denominamos esse princípio de alma individual, no segundo, de Alma do Mundo. Isso quer dizer que todas as almas individuais também são essa única Alma. A Alma é, pois, "um e múltiplo" (En. IV, 1, 2, 52: hén kaì pollá). Note-se, contudo, que, embora a Alma do Mundo seja a mesma em todos os indivíduos, estes não são idênticos entre si. A diversidade deles não pode ser assegurada pela composição da Alma com a matéria, pois há almas individualizadas mesmo antes de elas se encarnarem (e a matéria não é fonte de individuação). Tampouco a diferença entre elas pode ser dar no âmbito estritamente das formas, pois as almas não são as formas (que se encontram no Intelecto). A única possibilidade é a de elas se diferenciarem pelos lógoi que são as manifestações das formas nas almas. Os corpos individuais, isto é, os compostos de alma e corpo, são distintos entre si, mas a alma que neles habita não. A Alma do Mundo multiplica-se então nas almas individuais permanecendo uma só (cf. En. IV, 9, 5). Para concluir: a Alma hipóstase manifesta-se tanto na unidade (como a Alma do Mundo), quanto na pluralidade (como as almas individuais), mas, considerada em si mesma, transcende ambas essas determinaçóes ao ser simultaneamente una e múltipla (cf. En. IV, 3, 8, 2-3). 
Após esta descrição sumarizada das três hipóstases, resta dizer ainda, que entre elas não há uma precedência temporal, mas somente causal (cf. En. VI, 1, 6, 19-22). O Um não é, por conseguinte, o princípio temporal das outras duas hipóstases, mas apenas o seu princípio causal. Da mesma forma, o Intelecto não antecede temporalmente a Alma, pois, como já vimos, ele próprio está situado fora do tempo (logo não teria sentido algum em falar aqui de anterioridade temporal). O Intelecto alicerça-se, pois, na contemplação eterna do Um ou do Bem e essa contemplação é pensamento do seu próprio pensamento, ou seja, ao se pensar a si mesmo o Um perde a sua unidade prístina produzindo então a segunda hipóstase, isto é, Ele gera o Intelecto, mas isso ocorre sem que Ele deixe de ser o Um. A "passagem" de uma hipóstase para outra no sistema de Plotino é muito difícil de ser compreendida, pois a hipóstase originária não deixa de ser ela mesma, mesmo após a "produção" da hipóstase dela derivada. Assim, o Um continua sendo Um mesmo após o Intelecto ter sido gerado. De modo análogo, a Alma que se formará a partir do Intelecto, não fará com que esse deixe de ser o que ele é. A Alma, enquanto terceira e última hipóstase, possui um caráter essencialmente mediador, pois é ela que deve intermediar a relação das hipóstases com a matéria, bem como do mundo sensível, constituído por essa união da Alma com a matéria, com o Princípio (o Bem) do qual deriva e para o qual deve convergir a fim de experimentar a verdadeira felicidade. A essência mesma da Alma, por conseguinte, é estar situada entre o Um como princí- 
pio (processo produtor) e o Um como fim (processo soteriológico) (cf. En. VI, 2, 11, 24-27).

A "passagem" de cada uma das hipóstases para a outra e destas para o mundo sensível poderia então ser sinteticamente expressa pela seguinte fórmula emprestada do Parmênides de Platão (cf. En. V, 1, 8, 24-28): o Um gera o "um-múltiplo" (o Intelecto) que gera o "um e múltiplo" (a Alma) que, por sua vez, gera o múltiplo (o mundo sensível) ao entrar em contato com a matéria. Um passo muito esclarecedor das Enéadas também nos ajuda a visualizar melhor a relação dessas hipóstases entre si ao comparar o Bem (ou o Um) com o centro de uma circunferência, o Intelecto com o círculo imóvel que circunda esse centro e, por fim, a Alma com o círculo posto em movimento por meio do desejo e que gira sem cessar ao redor desse centro. Enquanto o Intelecto possui o Bem imediatamente (euthýs) a Alma deseja (ephietai) o que está lá (epékeina) (cf. En. IV, 4, 16, 23-27). O problema desse exemplo, bem como de qualquer exemplo, é que as metáforas nele utilizadas são sempre imprecisas para exprimir o pensamento. Assim, na verdade, o Um não é imóvel, pois como Plotino nos esclarece alhures, Ele é a própria potência do movimento e do repouso, situando-se, portanto, para além desses conceitos. $\mathrm{O}$ Intelecto, por sua vez, não é imóvel, pois ele move-se em relação ao Um (cf. En. III, 9, 7), mais precisamente, ele é "um movimento em direção ao Bem" (En. V, 6, 5, 8-10: kinesis pròs agathón). Ora, esse é o primeiro movimento que produz o pensamento (cf. En. VI, 6, 6, 31-33) criando, portanto, a partir do Um (hén) o 
Intelecto (hèn-pollá) (cf. En. V, 3, 15, 11). Vê-se então que o movimento e a alteridade nascem juntos, como diz Plotino (cf. En. II, 4, 5, 29-34), pois esse primeiro movimento instaura a primeira dualidade, a saber, aquela entre pensante e pensado. Quando essa busca pela alteridade se radicaliza, nasce então a Alma, pois ela é produzida pelo desejo do que está além dela, ou seja, ao perder o contato imediato com a contemplação do Bem, característica do Intelecto, a Alma, conquanto sempre permaneça em dependência para com o Um, busca na matéria a sua completude. A matéria, tal qual o Um, é "sem forma" (aneideón) (cf. En. II, 5, 4, 12 (sobre a matéria) e VI, 7, 33, 21 (sobre o Um)) e "sem limite" (ápeiron) (cf. En. II, 4, 15, 10 (sobre a matéria) e VI, 7, 32, 15 (sobre o Um)), de modo que se a Alma, tencionada que está entre o Um e o múltiplo (por isso ela é dita hén kaì pollá "una $e$ múltipla”) não se decidir pelo Um, ela se dispersará na pluralidade ilimitada da matéria. Logo, a Alma nunca deixará de estar circundando o Um, mas a diferença toda reside na direção para a qual ela se volta. Se ela, ansiando pela diversidade, olhar para fora do círculo, então ela se dissipará na multiplicidade. Todavia, se ela se esforçar para contemplar o centro de onde se originou, o Bem, lá ela encontrará a unidade que a apaziguará e a fará feliz. Mas, sendo por natureza a mediadora entre o Um e o múltiplo (ela é literalmente o "e" mediador que interliga o Um ao múltiplo), ela passará sucessivamente de um modo de contemplar ao outro. Assim, de uma visão exocêntrica que a levará à dispersão, ela poderá passar a uma visão endocêntrica 
que a fará encontrar o seu fim (télos) e o seu repouso (anápaula) e, deste modo, ela poderá, como diz uma bela imagem de Plotino, dançar "uma dança divinamente inspirada" (khoreían éntheon) ao redor do Um (cf. En. VI, 9, 8, 36-45).

Após esta breve exposição sobre as hipóstases em Plotino, bem como sobre a relação que elas estabelecem entre si, podemos finalmente voltar ao nosso tema e agora, com muito maior facilidade, compreender a relação do tempo com a alma. Retornemos, pois, à passagem do capítulo onze do tratado sobre a eternidade e o tempo que trata do vínculo entre a Alma e o tempo.

Como dizíamos então, essa é a passagem mais fundamental para nós, pois é nela que Plotino discorre mais extensamente sobre a relação da Alma com o tempo. Ele nos diz, primeiramente, que a origem do tempo deve ser buscada na eternidade, caracterizada como a vida do Intelecto, sinônimo de vida calma, coesa, infinita, completamente estável e voltada ao Um. Nessa fase, portanto, não há ainda vestígio do tempo. Como então ele será gerado? Não podendo recorrer às Musas para narrar a genealogia do tempo, dado que elas ainda não teriam nascido, pois, segundo uma tradição grega, ao serem filhas de Zeus e de Mnemosyne as Musas nascem no tempo, Plotino dá voz ao próprio tempo (ainda que num discurso indireto) para que ele mesmo narre o modo como se manifestou (ekphaneís) e originou (genómenos). E o tempo diz então, segundo Plotino, que no início, antes que gerasse o anterior (tò próteron) e que necessitasse do posterior (toû hystérou), ele 
repousava consigo mesmo no Ser do Intelecto, ou seja, na eternidade. Isto porque o tempo ainda não havia se manifestado, mas permanecia naquele Ser, i.é, na eternidade, igualmente em estado de quietude. Então, uma natureza inquieta (polyprágmonos, literalmente: que faz muitas coisas), desejosa de comandar a si mesma e de pertencer a si mesma, "decidiu buscar mais do que o presente e moveu a si mesma e moveu também ele <i.e. o tempo>" (En. III, 7, 11, 16-17: tò pléon tôิ paróntos zêteîn heloménes ekinéthe mèn auté, ekinéthe dè kaì autós). Esse relato mostra, com clareza, que é esse movimento da Alma, que busca algo além do que ela já possui, que cria o tempo. Não por acaso, quando Plotino trata do movimento, ele afirma que "também o tempo é a cada vez diverso, porque é o próprio movimento que o produz" (En. VI, 3, 22, 43-44: hóthen kaì ho khrónos héteron aei, dióti kinesis autòn poieî). Obviamente, o movimento (kinesis) a que Plotino se refere aqui é o movimento hipostático que se manifesta no plano do Intelecto na atividade de pensar (noeîn) (cf. En. VI, 7, 35, 2) e no plano da Alma pelo desejo (éphesis) (cf. En. III, 9, 9, 4).

Depois desse relato, onde o tempo é quase personalizado, Plotino passa a discorrer mais analiticamente sobre a gênese do tempo. Ele esclarece então que essa natureza inquieta (oukh hésykhos), a Alma, que habitava o Intelecto, desejosa de outras coisas além daquelas que lhe eram presentes, originou o cosmo sensível, segundo o modelo do cosmo inteligível, movido por um movimento diverso daquele que move o cosmo inteligível, mas que o imita (mimései) e que aspira a 
ser a sua imagem (eikóna). "Primeiramente", portanto, a Alma se temporalizou (ekhrónosen) produzindo no lugar da eternidade o tempo (cabe ressaltar que todos os termos com conotação temporal devem ser entendidos aqui metaforicamente, pois evidentemente o "processo" de criação do tempo não ocorre no tempo, por isso todos esses termos aparecem aqui entre aspas). "Depois" impôs ao mundo criado servir o tempo, na medida em que tudo fora criado no tempo e todos os processos do mundo foram circunscritos ao tempo. Note-se que, para Plotino, o cosmo sensível em sua totalidade encontra-se na Alma, pois como ele diz, não há outro lugar (tópos) para o cosmo senão a Alma e nela o cosmo se move no tempo. O ato seminal da Alma é, com efeito, a sua temporalização e é somente a partir desse "processo" que ela cria o cosmo sensível. Ao contrário do atuar simultâneo do Intelecto, a Alma produz uma coisa depois da outra, gerando assim a sucessão (tò ephexệs) e, ao invés de pensar sem mediação, como ocorria no plano do Intelecto, ela, em seu anelo pelo diverso, passa a pensar discursivamente, ou seja, na sucessão, de modo que agora se gera efetivamente a diferença temporal do passado e do futuro. A Alma parece então possuir dois estados: um "quando" se encontra no Intelecto de modo potencial e o outro "quando" o desejo a faz buscar fora de si aquilo pelo que anseia. O tempo sucessivo do cosmo sensível é a própria expressão deste "segundo momento" da Alma, por isso Plotino o define como sendo "vida da Alma em movimento de transição de um modo de vida para outro" (En. III, 7, 11, 44: psykhêes en kinései metaba- 
tikệi ex állou eis állon bion zoèn). Todavia, isso não quer dizer que no "primeiro estado" da Alma não houvesse tempo, mas sim apenas que naquele estado o tempo, tal qual a própria Alma, só existia em potência e não em ato.

O tempo, portanto, só pode ser entendido, segundo Plotino, ao ser relacionado com a eternidade, pois esta é a denominação da vida do Intelecto, vida da qual a Alma separou-se ao se temporalizar para viver a sua própria vida, denominada, como acabamos de ver, tempo. Por essa razão, o resto do capítulo onze tratará especificamente desse vínculo emulativo que a Alma possui em relação ao Intelecto. Assim, tal como o cosmo sensível é a imagem do inteligível, também a vida da Alma procura emular a vida do Intelecto. Logo, se a eternidade é a caracterização da vida no estado de quietude, uniformidade e identidade consigo mesma, o tempo será analogamente uma vida no estado de inquietude, diversidade e alteridade. A correspondência entre os atributos da eternidade e os do tempo deve ser perfeita, de modo que a cada atributo da eternidade corresponderá um atributo análogo do tempo.

O primeiro predicado da eternidade é a sua unidade (henós) e a esse predicado o tempo se refere ao ser uma imagem (eídolon) da unidade, a saber, "a unidade na continuidade" (tò en synekheíai hén); a segunda propriedade da eternidade é a sua "infinitude atual e completa" (apeírou éde kaì hólou) que o tempo imita ao ser "uma tendência ao infinito relacionada ao que será eternamente sucessivo" (tò eis ápeiron pròs tò ephexês aeî) e, por fim, a terceira e última característica da eternidade é ser uma "totalidade concentrada" 
(athróou hólou), característica essa emulada pelo tempo ao este ser "uma totalidade que se formará por partes e que será sempre futura” (tò katà méros esómenon kaì aè̀ esómenon hólon).

Plotino conclui esse capítulo enfatizando que o tempo não pode ser concebido fora da Alma, tal como a eternidade tampouco pode ser concebida fora do Intelecto. O tempo, por conseguinte, não é, para ele, uma consequência (parakoloúthema) da Alma, nem algo posterior (hýsteron) a esta, mas antes o tempo deve ser visto (enorómenon), ínsito (enónta) e conjugado (synónta) a esta, tal como a eternidade também deve ser vista no Intelecto, ínsita e conjugada a este. Em outras palavras, o tempo e a Alma não devem ser analisados separadamente, pois eles são eventos co-originários. Se há Alma, já há vida (potencial ou atual) da Alma que é tempo. Em suma: um não pode ser sem o outro.

O capítulo doze alude apenas à hipótese de que o cosmo sensível com a sua diversidade, bem como a distinção do anterior e do posterior e do passado e do futuro deixariam de existir caso a Alma não tivesse saído da unidade em que se encontrava com o Intelecto. Todavia, nos adverte Plotino, se o cosmo se imobilizasse, mas se a Alma continuasse em atividade, seria possível mensurar essa quietude da Alma. O tempo, como se vê, independe do movimento do cosmo, na medida em que ele depende diretamente da atividade da Alma. O cosmo, contudo, depende diretamente do tempo, pois ele é criado no tempo e todos os seus processos ocorrem no âmbito temporal, como vimos acima. Isso não quer dizer, entretanto, que o tempo 
"preceda" o cosmo cronologicamente, dado que eles são coetâneos, mas apenas que o cosmo é o produto da atividade da Alma que é denominada tempo. Ou seja: o tempo possui uma precedência causal e não temporal sobre o cosmo, pois o cosmo foi criado no tempo, enquanto o tempo se manifesta no cosmo. Por essa razão, Plotino explica que o tempo não é engendrado (gennêtheis) pelas revoluçóes dos corpos celestes, mas esse é apenas e tão-somente o modo por meio do qual ele se manifesta (delotheis) (cf. En. III, 7, 12, 51-52). Lembremo-nos, contudo, que "antes" de haver cosmo, o tempo já existia (potencialmente) na Alma que, por sua vez, já se encontrava em potência no Intelecto (cf. En. III, 7, 12, 8-25).

Por fim, Plotino voltará a tematizar explicitamente a relação da Alma com o tempo no último capítulo do seu tratado, a saber, no capítulo treze. Nesse capítulo, ele, mais uma vez, critica a posição que lhe parece absurda, defendida por aqueles que relacionaram o tempo apenas ao movimento inanimado. Isto porque neste movimento se pode diferenciar o anterior e o posterior, mas não o relacionaram ao movimento que verdadeiramente lhe origina e do qual o movimento inanimado é apenas uma imagem. Esse "movimento" animado para Plotino é naturalmente o "movimento" hipostático da Alma que produz o tempo e o cosmo e que, por ser um "movimento" espontâneo (autourgós, literalmente: auto-produtor) dá origem também ao anterior e ao posterior (cf. En. III, 7, 13, 30-40). Cabe observar, contudo, que o anterior e o posterior no âmbito do Intelecto não se relacionam segundo uma 
ordem temporal, mas apenas segundo a ordem (táxei) (cf. En. IV, 4, 1, 27-29).

Após reiterar, mais uma vez, a prioridade (causal, não temporal) da Alma sobre o tempo e o cosmo, Plotino nos fornece uma nova informação acerca da relação entre a Alma e o tempo. Ele afirma que o fundamento da ubiquidade (pantakhô̂) do tempo reside na ubiquidade da Alma, entendida aqui tanto como Alma do Mundo quanto como alma individual. $\mathrm{Ou}$ seja: assim como não pode haver nenhuma parte do mundo desprovida de vínculo com a Alma do Mundo, assim também não pode haver nenhuma parte do nosso corpo desprovida de vínculo com a nossa alma (cf. En. IV, 3, 3, 24; IV, 3, 9, 43-45 e VI, 4, 1, 25-26).

A seguir, Plotino procura ilustrar que se o movimento do cosmo deve ser compreendido à luz do movimento da Alma do Mundo, da mesma forma um movimento qualquer realizado por um homem deve ser entendido à luz do movimento de sua alma. Em outros termos: o quanto um determinado homem caminha fundamenta-se no respectivo movimento de sua alma que ocorre em intervalos iguais (cf. En. III, 7, 13, 53-62). O movimento da Alma, entretanto, não pode ser fundamentado em nenhum outro, dado ele ser um movimento auto-produtor.

Finalizando o seu tratado sobre a eternidade e o tempo Plotino se pergunta se o tempo também estaria em nós. A sua resposta é afirmativa, pois se o tempo está na Alma como a sua vida, e se as almas individuais são, apesar da diversidade que possuem entre si e com a Alma do Mundo, o tempo, por conseguinte, 
além de estar na Alma do Mundo se encontra também nas nossas almas. Por essa razão, do mesmo modo que não existem muitas almas, mas uma única que se manifesta na pluralidade, assim também não existem muitos tempos, mas apenas um único tempo que se manifesta em cada alma como a sua própria vida. Assim, a unidade do tempo se fundamenta na unidade da Alma (cf. En. III, 5, 4, 12), bem como a continuidade do tempo se fundamenta na continuidade da Alma (cf. En. IV, 3, 2, 35). Mas, na verdade, nem a Alma do Mundo, nem as almas individuais estão integralmente no tempo, mas somente as nossas ações e afecções são propriamente temporais, pois o tempo, que é a vida da Alma (tanto da Alma do Mundo, quanto das almas individuais), não pode ser confundido com o que se encontra no tempo, a saber, o cosmo, dado esse ser inferior ao tempo (cf. En. IV, 4, 15).

\section{CONCLUSÃO}

Após analisar isoladamente as posiçôes teóricas de Aristóteles e Plotino concernentes à relação entre a alma e o tempo, cabe-nos, por fim, estabelecer uma comparação mais direta entre esses autores a fim de mostrar, por trás da aparente semelhança que os une, a grande diferença que os separa.

Como vimos, a primeira semelhança é que ambos tratam explicitamente da relação entre psykhé e khrónos. Todavia, como mostramos anteriormente, a própria referência ao termo psykhé nos respectivos tratados do tempo de Aristóteles e Plotino é comple- 
tamente diversa. Para o Estagirita, psykhé refere-se à alma individual, mais precisamente, a sua referência é ao intelecto da alma individual, ou seja, à alma intelectiva de um indivíduo. Já para Plotino psykhé se refere à Alma enquanto hipóstase. Ambos os filósofos, entretanto, ainda que cada um a seu modo, estão longe de defender uma posição que nós poderíamos hoje denominar de psicologista ou subjetivista acerca da natureza do tempo, como ocorrerá posteriormente em alguns pensadores modernos. Nem mesmo de Agostinho poder-se-ia emitir tal juízo, pois não é possível entender suas profundas reflexóes sobre o tempo, contidas principalmente em suas célebres Confissōes, sem inserilas em seu contexto ontológico e teológico original.

No caso de Aristóteles, isso não é desse modo, pois ele não postula que o tempo seja algo que já exista a priori no intelecto humano, como Kant defenderá mais tarde, ao afirmar que o tempo existe a priori enquanto intuição pura, mas assevera apenas que o tempo só se manifesta propriamente quando o intelecto humano, o único capaz de numerar, numera efetivamente dois agoras, distintos entre si, que correspondem às duas etapas - inicial e final - do movimento ou da transformação de um ente móvel. O movimento ou a mudança de um ente físico, contudo, vale a pena lembrar, independe absolutamente do intelecto humano, mas ele ainda não é o tempo ele mesmo e sim apenas o seu quase substrato, por isso na ausência deste quase substrato - o movimento - não haveria propriamente o tempo. É certo que esse movimento não precisa ser necessariamente um movimento exterior, pois basta a 
percepção de um movimento interno para que a possibilidade de numerá-lo e, com isso, a possibilidade de se falar propriamente de tempo se manifeste (cf. Phys. IV 11, $\left.219 \mathrm{a}_{4-6}\right)$. Por outro lado, a capacidade de numerar presente no intelecto humano tampouco constitui por si só o tempo em sentido estrito, pois o tempo, para o Estagirita, não é apenas o número enquanto tal, mas o número de um movimento, qualquer que ele seja. Em outras palavras: o tempo surge somente da união entre uma capacidade epistemológica do intelecto humano e a realidade ontológica dos entes móveis que este intelecto procura conhecer. Note-se, no entanto, que numerar o tempo não quer dizer simplesmente percebê-lo. Com efeito, Aristóteles se refere sempre à percepção de dois agoras, correlatos a duas etapas de um movimento, interno ou externo, e não propriamente a uma percepção do tempo (cf. Phys. IV $10,218 \mathrm{~b}_{31}, 11,219 \mathrm{a}_{24-25}$ e 11, $219 \mathrm{a}_{33}-\mathrm{b}_{1}$ ). Apenas em uma única passagem do seu tratado ele se refere explicitamente à percepção do tempo (cf. Phys. IV 10, $219 \mathrm{a}_{3-4}$ ), ao falar da simultaneidade (háma) com que nós percebemos o movimento e o tempo. Nessa passagem, contudo, ele não nos parece falar stricto sensu de uma percepção do tempo, mas apenas discorrer de modo genérico acerca de um complexo processo de percepção das etapas de um movimento que podem ser numeradas pelo intelecto humano. Isso porque não pode haver percepção do tempo propriamente dita ao ser este um universal e não algo particular. E, para o Estagirita, movimento e percepção são sempre relativos a um particular. Ao contrário, o tempo como 
universal só se manifesta propriamente então quando nós numeramos distintas fases de um movimento determinado. É exclusivamente por causa dessa universalidade do tempo que ele pode ser o mesmo para diferentes movimentos, e é por essa razão também que só o homem é capaz de conhecer o tempo (os animais podem perceber o anterior e o posterior de um dado movimento, mas não são capazes de numerá-lo, pois são incapazes de possuírem um conhecimento universal) (cf. Metaph. A 1, $980 \mathrm{~b}_{27-28}$ ).

No caso de Plotino, tampouco é lícito falar em psicologização ou subjetivização do tempo, pois ele nem mesmo está se referindo à alma individual, mas sim à terceira hipóstase de sua doutrina que ele denomina Alma. Ora, nessa doutrina só seria válido falar então propriamente de henologização do tempo, caso se queira usar um rótulo qualquer, pois, para Plotino, tudo deriva do Um e para Ele converge, inclusive o tempo. $\mathrm{Na}$ verdade, o tempo é para ele o ato seminal da Alma por meio do qual ela, iludida pelo reflexo do intelecto por ela mesma criado, se temporaliza a fim de alcançar essas imagens que ela plasma na matéria. É esse seu desejo de algo futuro que a faz sair de seu estado latente no interior do Intelecto e a faz buscar incessantemente aquilo que acredita não possuir ainda. $\mathrm{O}$ tempo, dentro desse quadro, é como que um mal necessário, pois sem ele o mundo não teria sido produzido. Digo "como que" um mal necessário, pois para Plotino, ao contrário dos gnósticos que combateu arduamente, o mundo, e consequentemente o tempo que o origina, não é um mal em si mesmo, mas será um mal tão 
somente se nos recusarmos a ver nele uma mera cópia do Intelecto e, por conseguinte, se nos perdermos na multiplicidade indefinida inerente à matéria. Todo o problema para Plotino reside, pois, como já dissemos, na direção para a qual voltamos o nosso olhar. Se contemplarmos o nosso interior, lá encontraremos o Intelecto e o Um, contudo, se olharmos para fora de nós, ou seja, se nos lançarmos em uma busca exocêntrica, jamais encontraremos a paz e a felicidade, mas apenas a multiplicidade dispersante da matéria ilimitada.

Pode-se falar, contudo, no caso de Plotino de uma descosmologização do tempo ao compararmos as suas análises de Platão no Timeu e de Aristóteles na Física. Com efeito, o que ocorre é que na sua investigação Plotino quer negar qualquer vínculo entre o movimento e a alma, vínculo este estabelecido, de um modo ou de outro, por todos os pensadores que o precederam. O que ele realmente faz, entretanto, não é eliminar a relação entre movimento e tempo, dado que a sua própria definição do tempo como vida da Alma, oculta a clara relação, por ele mesmo estabelecida alhures, entre movimento e vida (cf. En. VI, 3, 22, 15-19), mas sim reinterpretar o sentido do termo movimento. Ou seja: o movimento que, segundo ele, está associado ao tempo, não é um movimento físico qualquer, nem mesmo o movimento das esferas celestes, mas sim o movimento hipostático da Alma. Para Plotino o tempo não pode ser algo do movimento, isto é, um atributo do mesmo, como queria Aristóteles, dado que para ele o movimento, bem como o próprio cosmo, é que estão na Alma. Note-se bem: o 
movimento que se encontra na Alma é o físico, não o movimento hipostático da própria Alma que é aquele que, na verdade, produz o tempo e o cosmo. O tempo, portanto, é, segundo a sua doutrina, produzido pelo movimento hipostático da Alma, ou seja, o tempo é a própria vida da Alma, caracterizada pelo fato de esta aspirar a algo para além do que já possui. Nessa concepção, por conseguinte, os astros, diferentemente do que ocorria no cosmo aristotélico, podem apenas se manifestar, mas não produzir o tempo, pois este é, enquanto vida da Alma, a causa efetiva da criação do cosmo sensível. Diante dessa nova concepção do mundo físico - em comparação com a de Aristóteles - o movimento não se diferencia mais da atividade pelo fato de ser necessariamente temporal e esta não, como na filosofia aristotélica, mas ambos - movimento e atividade - são igualmente atemporais, com a óbvia exceção do movimento extenso (cf. En. VI, 1, 16, 15 ss. e a posição contrária de Aristóteles que afirma o caráter intrinsecamente temporal de todo e qualquer tipo de movimento em Phys. $232 \mathrm{~b}_{20 \text { ss }}$ e $235 \mathrm{a}_{10-17}$ ). Tampouco causa surpresa que o tempo, para Plotino, não seja caracterizado como uma quantidade (cf. En. VI, 1, 5, 14-19) - ao contrário do que pensava o Estagirita (que subscrevia o tempo à categoria da quantidade tanto em suas Categorias quanto no Livro Delta da Metafisica) -, dado ele ser mais precisamente um modo de vida, qual seja, a vida da Alma e esta, por sua vez, possui uma natureza essencialmente não quantitativa (áposon) (cf. En. IV, 7, 5, 51). Evidentemente, também o conceito de eternidade (aión) é pensado de 
modo completamente distinto por Aristóteles e por Plotino. Enquanto para o Estagirita a eternidade é pensada em conjunção com o tempo (cf. De caelo 279 $\mathrm{a}_{26 s \mathrm{~s}}$ e $283 \mathrm{~b}_{9_{\mathrm{ss}}}$ ), para Plotino ela é o modelo (a vida do Intelecto) segundo o qual o tempo (a vida da Alma) é produzido. Em suma: se para Aristóteles o tempo é algo que não pode existir além do céu (cf. De caelo 279 $\mathrm{a}_{12}$ ), para Plotino, bem como para Platão - ao menos segundo Plotino o interpretava - o tempo não é uma realidade meramente física, mas sim metafísica, a saber, a imagem da eternidade - na leitura que Plotino faz de Platão - ou a vida da Alma como imagem da vida do Intelecto, segundo a concepção própria de Plotino.

Um fato que denota esse pouco interesse de Plotino pelo aspecto cosmológico e quantitativo presente no tratamento dado por Platão (no Timeu) e Aristóteles ao tempo é que quando ele se refere ao que interpreta como sendo a definição platônica do tempo, "imagem móvel da eternidade", ele sempre omite dessa definição a referência explícita feita por Platão à ordenação numérica que essa imagem obedece (cf. En. III, 7, 11, 20; III, 7, 12, 27 e III, 7, 13, 24). Ora, essa ausência de tematização do problema do número no âmbito da análise sobre o tempo é plenamente compreensível ao sabermos que para Plotino, por um lado, o tempo, não é uma quantidade, e que, por outro, o número, é concebido de forma totalmente não quantitativa, pois, segundo ele, a própria Alma - avessa à quantidade, como vimos acima - é número porque é uma essência (cf. En. V, 1, 5, 9 e VI, 6, 16, 45) e não um corpo ou uma grandeza como ele parece atribuir, 
ainda que erroneamente, a Aristóteles (cf. En. VI, 6, 16, 44 e para a definição aristotélica de alma cf. De an. $412 \mathrm{a}_{16-27}$ onde o Estagirita explica claramente que a alma não é simplesmente idêntica ao corpo, mas é, na verdade, a forma desse corpo).

O número, no caso do tratado do tempo de Aristóteles, está intrinsecamente relacionado com o agora, pois, na realidade, o que é propriamente numerado são os agoras que correspondem às etapas, anterior e posterior, por nós percebidas em um movimento ou mudança qualquer, por isso o Estagirita diz explicitamente que "o agora é o anterior-posterior enquanto numerável” (Phys. IV 11, $219 \mathrm{~b}_{25}$ : hêi i d'arithmêtòn tò próteron kaì hýsteron, tò $n \hat{y} n$ éstin). Vê-se, portanto, que para Aristóteles, embora não pertença formalmente à sua definição do tempo, o agora (nŷn) é absolutamente indispensável para se entender a natureza do tempo (cf. Phys. VIII 1, $251 \mathrm{~b}_{19-20}$ ). Isso é assim, porque, segundo ele, é precisamente por meio do agora que o tempo é divisível e contínuo (cf. Phys. IV 11, $220 \mathrm{a}_{4-5}$ ).

É digno de atenção, por conseguinte, que um conceito - o agora - tão fundamental para Aristóteles seja completamente ignorado na análise de Plotino sobre o tempo. Nem mesmo quando ele investiga especificamente a posição do Estagirita sobre o tempo ele se refere ao conceito de agora. Provavelmente, isso ocorre porque Plotino quer eliminar a noção numérica (na sua acepção quantitativa) da sua análise acerca do tempo (por isso, como mostramos mais acima, até mesmo quando se refere ao Timeu ele elimina a referência explícita de Platão à dimensão numérica), mas também 
porque ele não precisa, ao contrário de Aristóteles, do conceito de agora para poder estabelecer a continuidade do tempo, dado que esta, no seu pensamento, é estabelecida pela própria Alma (o tempo é contínuo, como vimos, porque a Alma que o produz está em todo lugar).

Cabe finalizar esta conclusão dizendo que, conquanto a análise do tempo como uma realidade propriamente psíquica e pessoal só apareça na Modernidade, dado que nem mesmo a célebre reflexão de Agostinho nas Confissóes pode ser interpretada desse modo, a investigação sobre o tempo em Plotino parece iniciar, ainda que não intencionalmente, uma tendência crescente à interiorização do tempo. Isso ocorre à revelia do próprio Plotino, pois para ele, embora a produção do tempo de modo algum esteja associada à alma individual, mas sim à Alma enquanto hipóstase, os termos que ele se utiliza para se referir aos movimentos hipostáticos - quer do Intelecto, o pensamento, quer da Alma, o desejo - são termos intrinsecamente relacionados à dimensão psíquica dos homens. Mais ainda: a sua concepção do movimento como vida, vida essa que pode ser qualificada como pertencente ao Intelecto, no caso da eternidade, ou à Alma, no caso do tempo, também é um conceito retirado da experiência cotidiana dos homens.

A utilização desses termos (pensamento, desejo e vida), portanto, parece ter influenciado - por meio da mediação dos Padres gregos, em especial de Basílio de Cesaréia, e latinos, particularmente Ambrósio de Milão - Agostinho em sua originalíssima análise sobre 
o tempo, mas essa é outra etapa da história da noção de tempo que no âmbito deste texto não nos é permitido abordar. 


\section{BIBLIOGRAFIA}

\section{A. FONTES:}

\section{ARISTÓTELES:}

Aristotle's Physics, a Revised Text with Introduction and Commentary by W.D.Ross, Clarendon Press, Oxford, 1955. Aristotle's Physics. Books III and IV, Translated with Introduction and Notes by E.Hussey, Clarendon Press, Oxford, 1985. Aristoteles' Physik, Übersetzt, mit einer Einleitung und mit Anmerkungen herausgegeben von H.G.Zekl, GriechischDeutsch, Felix Meiner, Hamburg, 1987 und 1988.

Aristote, Traité du Temps, Introduction, Traduction et Commentaire, Éditions Kimé, Paris, 1994.

Aristóteles, Física. Libros III-IV, Traducción, Introducción y Comentario por A.G.Vigo,

Editorial Biblos, Buenos Aires, 1995. 


\section{PLOTINO:}

Plotinus, The Enneads, Ed. A.H.Armstrong, CambridgeMass. (Loeb Classical Library), vols. I - VII, 1966- 1968.

Plotino, Enneadi, Traduzione con testo greco a fronte, Introduzione, Note e Bibliografia di G.Faggin, Rusconi, Milano, 1992.

Plotino, Enéadas III-IV, Introducción, Traducción y Notas de J.Igal, Gredos, Madrid, 1985.

Plotin, Über Ewigkeit und Zeit (Enneade III 7), Übersetzt, Eingeleitet und Kommentiert

von W.Beierwaltes, Vittorio Klostermann, Frankfurt am Main, $1981^{3}$.

Plotino, L'Eternità e il Tempo (Enneade III 7), Traduzione e Commento di F.Ferrari e

M.Vegetti, Egea, Milano, 1991.

\section{B. ESTUDOS ESPECÍFICOS SOBRE O TEMPO:}

\section{ARISTÓTELES:}

Cavagnaro-Stuijt, E. - Aristotele e il Tempo. Analisi di Physica IV 10-14, Leeuwarden, 1995.

Conen, P. Die Zeittheorie des Aristoteles, C.H.Beck, München, 1964.

Dubois, J. Le Temps et l'Instant selon Aristote (Physica IV, 1014), Desclée Brouwer, Paris, 1967.

Festugière, A.J. "Le temps et l'âme selon Aristote", Études de Philosophie Grecque, Vrin, Paris, 1971. 
Goldschmidt, V. Temps physique et Temps tragique chez Aristote. Commentaire sur le

Quatrième Livre de la Physique (10-14) et sur le Poétique, Vrin, Paris, 1982.

Ruggiu, L. Tempo, Coscienza e Essere nella Filosofia di Aristotele. Saggio sulle Origini del Nichilismo, Paideia Editrice, Brescia, 1970.

Verbeke, G. "La perception du temps chez Aristote", Cahiers de Philosophie Ancienne, 3, Aristotelica. Méllanges offerts à M.Corte, Éditions Ousia, Bruxelles, 1985.

Volpi, F. "Chronos und Psyche. Die aristotelische Aporie von Phys. IV 14, $223 \mathrm{a}_{16-19}$ ",

Zeit, Bewegung, Handlung. Studien zur Zeitabhandlung des Aristoteles, Hrsg. E.Rudolph, Klett-Cotta, Stuttgart, 1988.

\section{PLOTINO:}

Brague, R. "Pour en finir avec 'le temps, image mobile de l'eternité'(Platon, Timée, 37d)", Du Temps chez Platon et Aristote. Quatre Etudes, PUF, Paris, 1982.

Gloy, K. "Die Struktur der Zeit in Plotins Zeittheorie", Archiv für Geschichte der Philosophie, 71, 1989.

Guitton, J. Le Temps et l'Eternité chez Plotin et St.Augustin, Vrin, Paris, 1959.

Lassegue, M. "Le temps, image de l'eternité, chez Plotin", Revue philosophique de la

France et de l'Etranger, CLXXII, 1982. 
Pigler, A. "Plotin exégète de Platon? La question du temps", Revue philosophique de la France et de l'Etranger, CLXXXVI, 1996.

Reis, J. "O tempo em Plotino", Revista Filosófica de Coimbra, 6, 1997.

Schwyzer, H.R. "Plotinus", Real-Encyclopädie (Artikel), XXI, Stuttgart, 1951.

Smith, A. "Eternity and Time", The Cambridge Companion to Plotinus, ed. L.P.Gerson, Cambridge University Press, New York, 1996.

Trotta, A. "Interpretazione e critica di Plotino della concezione del tempo dei suoi predecessori", Rivista di Filosofia neo-scolastica, 2-3, 1992. 


s formas básicas de conceber metaforica-
mente o tempo - como circunferência e
como linha reta - estão intimamente relacionadas com dois modos elementares, porém evidentemente não os únicos, de se experienciar o tempo. Os gregos vivenciaram-no tanto como um processo repetitivo, quanto como um escoar irreversível.

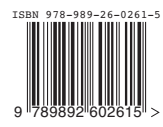

